\title{
SELEÇÃO PARA CARACTERES AGRONÔMICOS, EM DIFERENTES ÉPOCAS DE CULTIVO, DE POPULAÇÕES DE SOJA COM RESISTÊNCIA A INSETOS
}

JOSÉ BALDIN PINHEIRO

Engenheiro Agrônomo

Orientador: Prof. Dr. NATAL ANTONIO VELLO

Tese apresentada à Escola Superior de Agricultura "Luiz de Queiroz", da Universidade de São Paulo, para obtenção do título de Doutor em Agronomia. Área de concentração: Genética e Melhoramento de Plantas.

PIRACICABA

Estado de São Paulo - Brasil

Fevereiro - 1998 


\section{Dados Internacionais de Catalogação na Publicação (CIP) DIVISÃO DE BIBLIOTECA E DOCUMENTAÇÃO - Campus "Luiz de Queiroz"/USP}

\section{Pinheiro, José Baldin}

Seleção para caracteres agronômicos, em diferentes épocas de cultivo, de populaçōes de soja com resistência a insetos / José Baldin Pinheiro. - - Piracicaba, 1998.

$$
143 \mathrm{p} .
$$

Tese (doutorado) - - Escola Superior de Agricultura Luiz de Queiroz, 1998. Bibliografia.

1. Genótipo vegetal 2. Melhoramento genético vegetal 3. População genética 4. Resistência a inseto 5 . Seleção genética 6 . Soja I. Título 


\section{SELEÇÃO PARA CARACTERES AGRONÔMICOS, EM DIFERENTES ÉPOCAS DE CULTIVO, DE POPULAÇÕES DE SOJA COM RESISTÊNCIA A INSETOS}

JOSÉ BALDIN PINHEIRO

Aprovada em: 21.08.1998

Comissão Julgadora:

Prof. Dr. Natal Antonio Vello ESALQ/USP

Prof. Dr. José Djair Vendramim ESALQ/USP

Prof. Dr. Lázaro José Chaves EAUUF

Dr. Carlos Jorge Rossetto

IAC

Dr. Léo Zimback

IAC

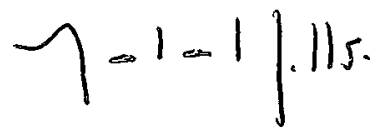

Prof. Dr. Natal Antonio Vello

- orientador - 
... nem a ciência nem a técnica podem exibir, em nenhuma circunstância, a bandeira branca de uma pretensa neutralidade. Todo gesto científico jorra idealogia. Todo técnico, todo cientista é sempre um politica."

D. $\mathscr{P}$ edro Casaldáglia 
Aos meus pais

João e Anna

A

Jorge, Rita, Gabriel e Filipe

DEDICO

$\grave{A}$

Imaculada

OFEREÇO 


\section{AGRADECIMENTOS}

- A Deus, pelo Dom da vida;

- Ao Professor Dr. Natal Antonio Vello, pela confiança, orientação, ensinamentos, paciência e amizade, fatores estes decisivos na realização deste trabalho;

- Ao Dr. Carlos Jorge Rossetto, pelo constante estímulo científico e pelo material genético para o início dos trabalhos;

- A Fundação de Amparo à Pesquisa do Estado de São Paulo (FAPESP) e à Coordenadoria de Aperfeiçoamento de Ensino Superior (CAPES), pela concessão da bolsa de estudo;

- Ao CNPq e a FAPESP, pelo financiamento de projetos durante a fase de desenvolvimento do germoplasma principal avaliado neste trabalho;

- A Escola de Agronomia da Universidade Federal de Goiás, pelo apoio para a conclusão desta tese;

- Ao grande amigo Dr. Nelson Fonseca da Silva Júnior, pelo precioso auxílio nas análises estatísticas;

- Aos amigos Luciano Lourenço Nass e João Batista Duarte, pela revisão deste trabalho e pelas valiosas sugestões apresentadas;

- Aos Professores e amigos Lázaro José Chaves e Edward Madureira Brasil, pelo constante apoio nesta nova etapa de minha vida;

- Aos amigos do grupo de soja, Sérgio, Joaquim, Regina, Gilberto, Dario, Luis Fernando, Juan Carlos, Wagner, João Tomé, Francilene, Milton, Angela, Diego, Sandra, Mônica, Fernando e Maurisrael pelo auxílio e constante apoio nos trabalhos experimentais;

- Aos funcionários do Laboratório de Soja, Antônio Roberto Cogo, Claudinei Antônio Didoné e Marcos Custódio Nekatschalow, pela colaboração nos trabalhos experimentais; 
- Às bibliotecárias Silvana Marchizelli Gregório e Aparecida Elisabeth dos Santos, pela revisão das referências bibliográficas e pela atenção sempre dispensada;

- Ao funcionário do Instituto Agronômico de Campinas Archangelo Marion, pelo auxílio nos experimentos;

- Aos amigos Paulo Roberto Utunomiya, Sérgio Renato Artiaga da Rosa, Juliana Azevedo Ruggiero, Américo José dos Santos Reis e Mara Fernandes Moura, pelo auxílio valioso na confecção das tabelas e constante estímulo;

- A Maria do Rosário Zucchi, pelo apoio na digitação deste trabalho;

- A Maria Imaculada Zucchi, pela compreensão nos momentos de ausência e constante dedicação;

- Aos amigos Vera Quecini e Antonio Augusto Franco Garcia, pelas sugestões oferecidas;

- A todos que de uma maneira ou de outra, contribuíram para que este trabalho fosse realizado. 


\section{SUMÁRIO}

página

RESUMO

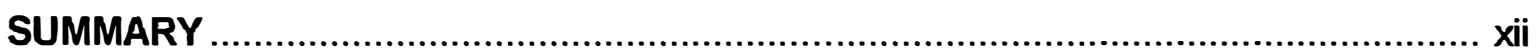

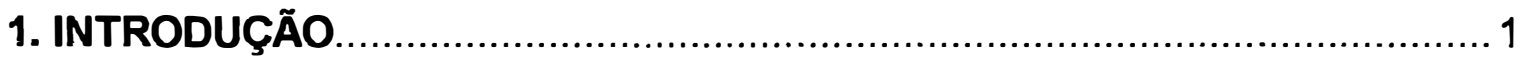

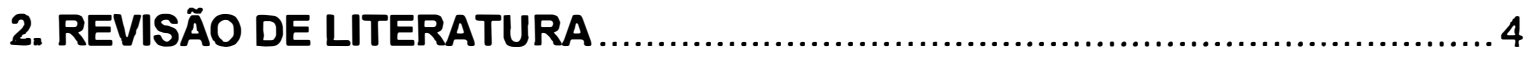

2.1. Origem da soja e do germoplasma brasileiro ............................................ 4

2.2. Resistência genética de soja a insetos .......................................................... 6

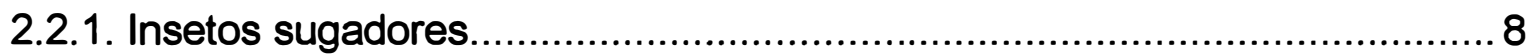

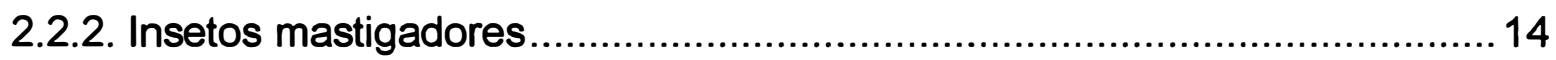

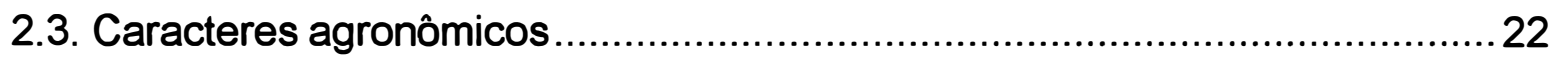

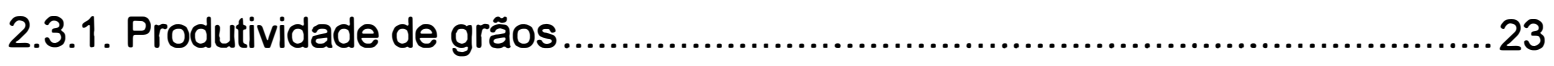

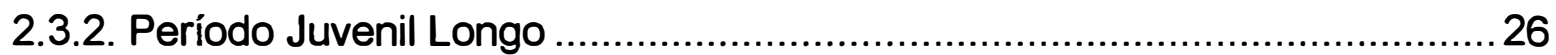

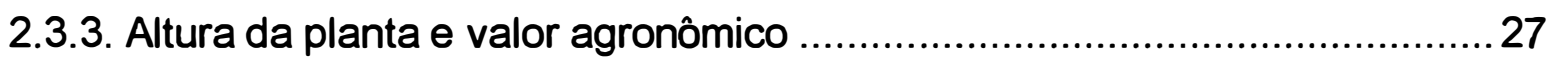

2.4. Estimativas de parâmetros genéticos ............................................................. 28

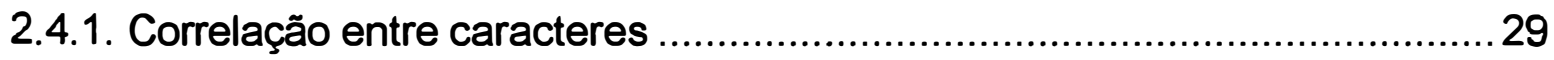

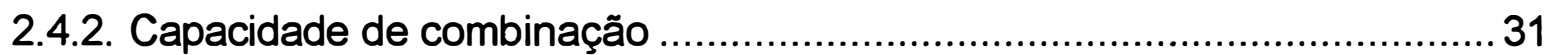

2.5. Delineamentos aumentados e o melhoramento de plantas ......................... 32

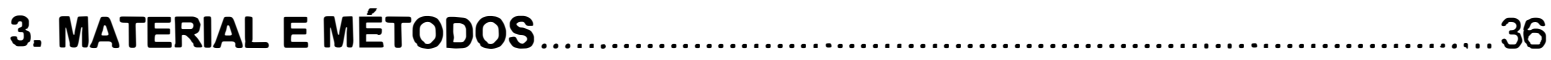

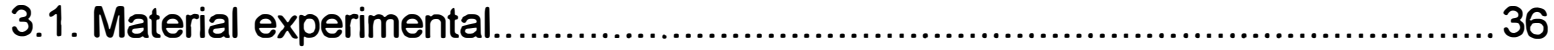

3.2. Ambiente de condução dos experimentos ............................................. 37

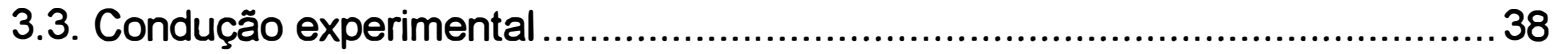

3.3.1. Populações com Controle de Insetos (PCl) .............................................38

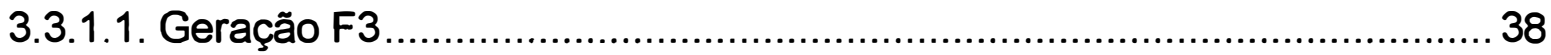




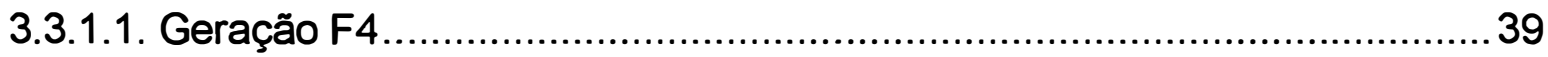

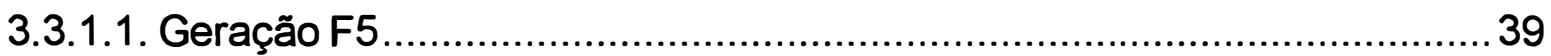

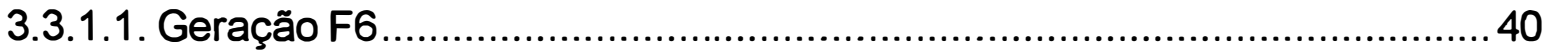

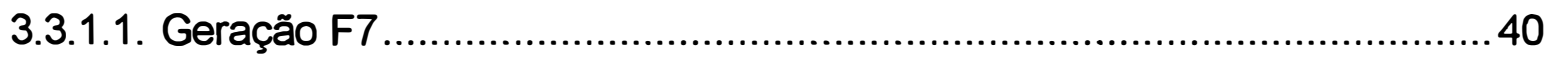

3.3.2. Populações Resistentes a Insetos Sugadores (PRIS) ............................41

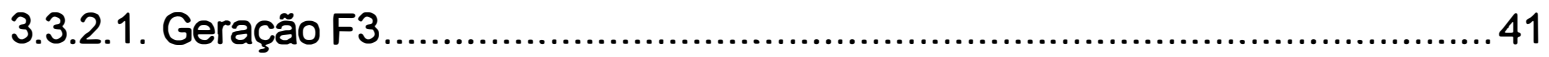

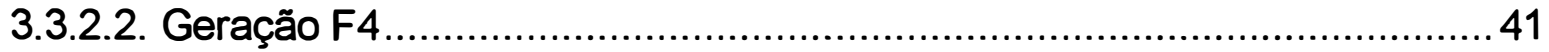

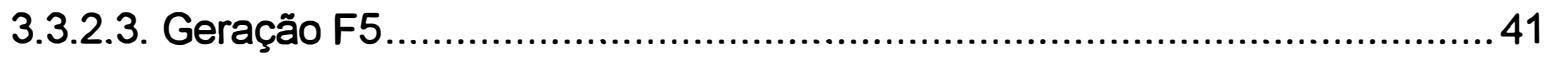

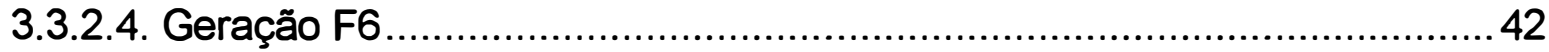

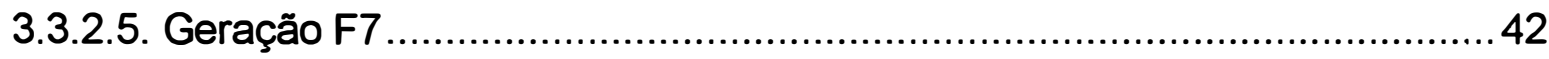

3.3.3. Populações Resistentes a Insetos Mastigadores (PRIM) ......................... 43

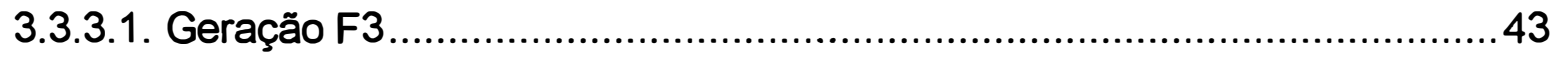

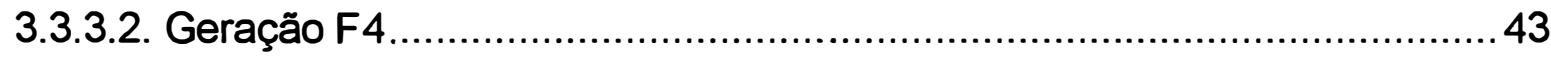

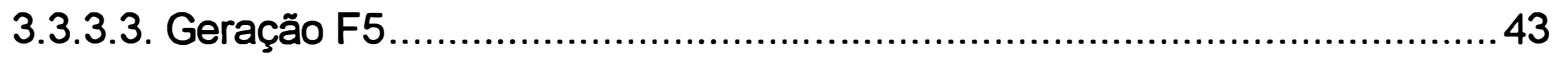

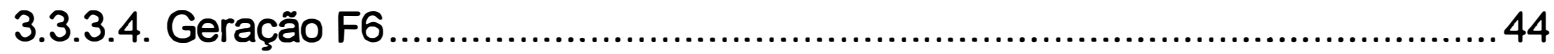

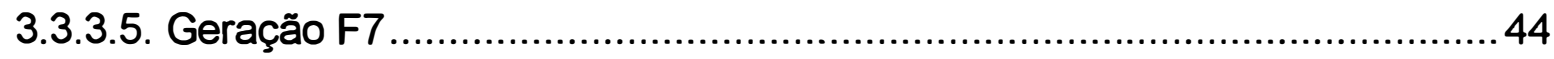

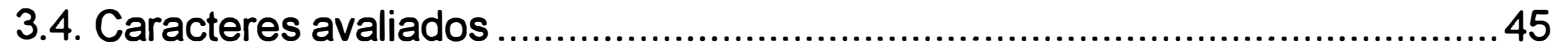

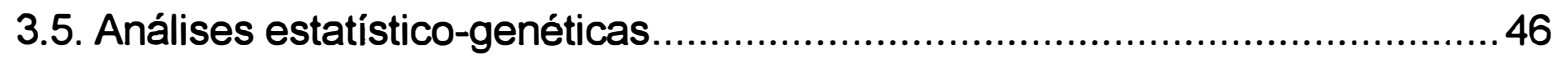

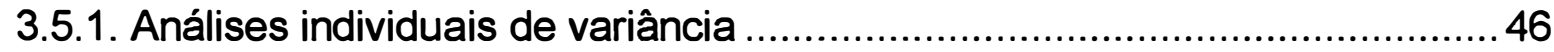

3.5.2. Análise de variância envolvendo diferentes ambientes ...........................4 47

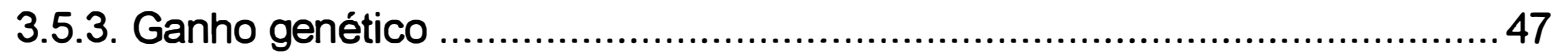

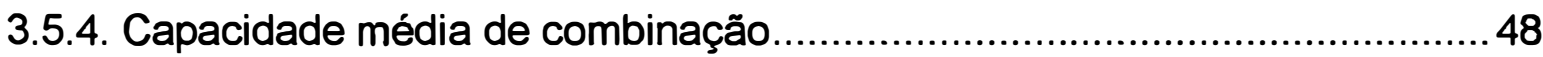

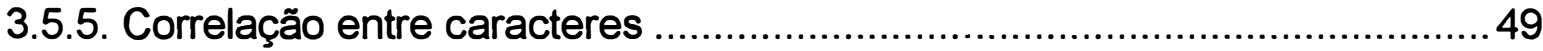

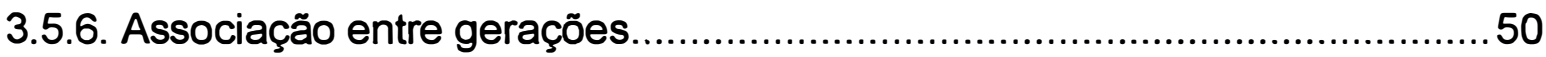

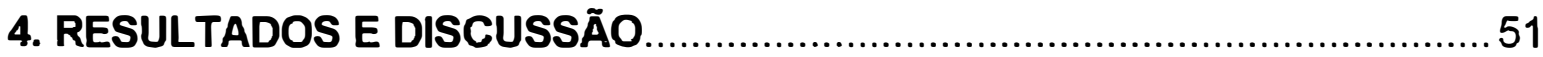

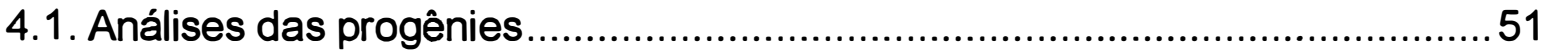

4.1.1. Populações com Controle de Insetos (PCl) ..........................................51

4.1.2. Populações Resistentes a Insetos Sugadores (PRIS) ...............................55

4.1.3. Populações Resistentes a Insetos Mastigadores (PRIM) ..........................59 
4.1.4. Considerações sobre a análise das progênies .......................................62

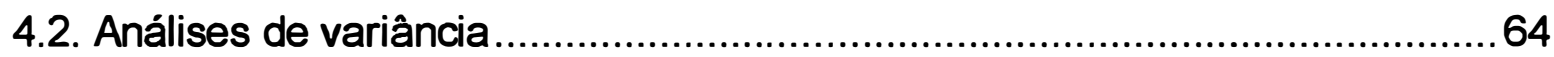

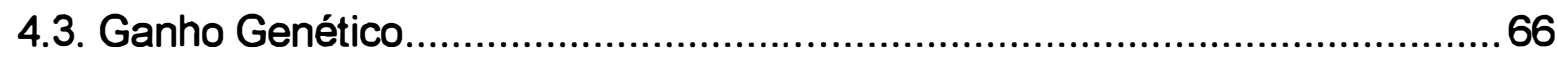

4.4. Capacidade média de combinação.........................................................68

4.5. Correlação entre caracteres ...................................................................69

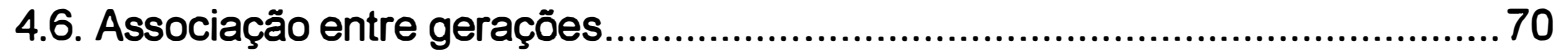

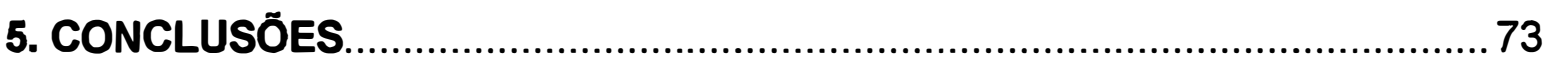

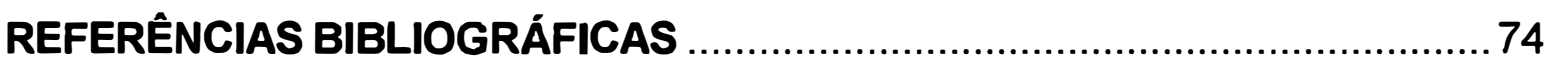

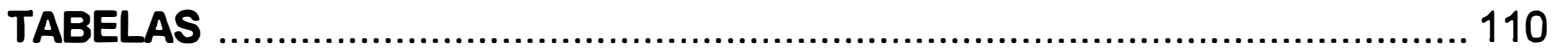

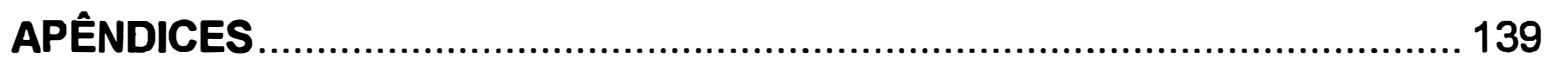




\title{
SELEÇÃO PARA CARACTERES AGRONÔMICOS, EM DIFERENTES ÉPOCAS DE CULTIVO, DE POPULAÇÕES DE SOJA COM RESISTÉNCIA A INSETOS
}

\author{
Autor: José Baldin Pinheiro \\ Orientador: Prof. Dr. Natal Antonio Vello
}

RESUMO

Este trabalho faz parte do programa em andamento no Setor de Genética Aplicada às Espécies Autógamas do Departamento de Genética da ESALQ/USP, e teve por objetivo verificar o potencial de genótipos de soja para o cultivo fora da época normal, além de reunir alelos favoráveis para alta produtividade e resistência a percevejos sugadores. O material experimental envolveu diferentes populações obtidas a partir de cruzamentos dialélicos parciais entre genótipos resistentes e suscetíveis a insetos. Como parentais resistentes utilizaram-se os cultivares Crockett, Lamar, IAC-100 e a linhagem experimental D72-9601-1. Como parentais suscetiveis, mas produtivos e adaptados, empregaram-se os cultivares BR-6 (Nova Bragg), IAS-5, Davis e OCEPAR-4 (Iguaçu). As gerações $F_{4}, F_{5}, F_{6}$ e $F_{7}$ dos diferentes tipos de populações foram avaliadas para os caracteres número de dias para a maturidade, altura da planta na maturidade, valor agronômico e produtividade 
de grãos. Os experimentos foram conduzidos na Estação Experimental de Anhembi e no campo experimental do Departamento de Genética, ambos pertencentes à ESALQ/USP. Foram utilizados os delineamentos de blocos aumentados (gerações $F_{3}$ a $F_{6}$ ) e blocos ao acaso com repetições estratificadas em conjuntos experimentais com testemunhas comuns (geração $F_{7}$ ); as análises estatístico-genéticas foram feitas para cada experimento e compreenderam: análise de progênies (com estimativas de médias e variâncias), ganho genético, capacidade média de combinação, correlação fenotípica entre os caracteres e associação entre as gerações. A partir da interpretação dos resultados as seguintes conclusões foram extraídas deste trabalho: (a) maior número de progênies foram selecionadas nos cruzamentos que envolveram o parental IAC-100, e estas apresentaram performance superior, para todos os caracteres avaliados, nos diferentes tipos de populações e gerações de endogamia; (b) para a capacidade média de combinação $\left(\mathrm{cmc}_{\mathrm{i}}\right)$, aumentando a expressão dos caracteres nos ambientes avaliados, destacaram-se os parentais: IAC-100, Davis e OCEPAR-4; (c) dentre os cruzamentos avaliados os mais produtivos são: IAS-5 x IAC-100, Davis $x$ IAC-100 e OCEPAR-4 x IAC-100; (d) alguns dos cruzamentos avaliados apresentam elevada variabilidade, o que viabiliza a obtenção de ganhos futuros na seleção de linhagens dentro destes cruzamentos; (e) o valor agronômico, mesmo sendo um caráter subjetivo, é útil na avaliação da produtividade em genótipos de soja; (f) a alta correlação entre o número de dias para a maturidade e produtividade de grãos dificulta a obtenção de genótipos precoces e produtivos; ( $\mathrm{g}$ ) as populações resistentes a insetos sugadores apresentaram progênies com maior valor agronômico e resistência a percevejos; (h) maior progresso de seleção pode ser alcançado quando esta é praticada no ambiente de cultivo. 


\title{
SELECTION FOR AGRONOMIC TRAITS, AT DIFFERENT GROWING SEASONS, IN SOYBEAN POPULATIONS WITH RESISTANCE TO INSECT PEST
}

\author{
Author : José Baldin Pinheiro \\ Adviser : Prof. Dr. Natal Antonio Vello
}

\section{SUMMARY}

This research work is a part of to the soybean breeding program of the Department of Genetics at ESALQ/USP, and its objective was to verify the potential of soybean lines under out of season cultivation, besides joining high yield and insect resistance-favoring alleles. Experimental material envolved different populations obtained from partial diallel crosses between insect resistant and susceptible cultivars. As resistant parents, the cultivars Crockett, Lamar, IAC-100 and the experimental line D72-9601-1 were employed. As susceptible, but highly yielding and adapted parents the cultivars BR-6 (Nova Bragg), IAS-5, Davis and OCEPAR-4 (Iguaçu) were employed. The progenies $F_{4}, F_{5}, F_{6}$ and $F_{7}$ from different types of population were evaluated to the following characters: days to maturity, plant height at maturity, agronomic value and grain yield. The experiments were carried out at Anhembi Experimental 
Station and the experimental field at the Department of Genetics, both belonging to ESALQ/USP. The experimental designs were augmented blocks (progenies $F_{3}$ and $\left.F_{6}\right)$ and randomized complete blocks with replicates stratified in experimental sets with common controls (progeny $F_{7}$ ); statistical-genetic analysis were carried out for each experiment and comprised progeny analysis (with media and standard deviation), genetic gain, average combining ability, phenotypic correlation among characters and generation association. Data interpretation led to the following conclusions: (a) higher number of progenies were selected from crossing envolving the parent IAC-100, these progenies showed superior performance to all evaluated characters for the different types of populations and inbreeding generations; (b) concerning to average combining ability were obtained with IAC-100, Davis and OCEPAR-4 as parent; (c) among the evaluated crosses, those with higher yields were: IAS-5 x IAC-100; Davis $x$ IAC-100 and OCEPAR-4 x IAC-100; (d) some of the evaluated crosses showed elevated variability, that makes feasible to obtain further gains from line selection within these crosses; (e) agronomic value, although being a subjective character, is useful in yield evaluation for soybean genotypes; (f) the high correlation between the number of days to maturity and grain yield is a difficulty to obtain early and high-yielding genotypes; (g) sucker insects populations resistant showed progenies with higher agronomic value and insect resistance; (h) higher genetic gain was observed when the selection was practised ind the same environment of the cultivation. 


\section{INTRODUÇÃO}

O cultivo da soja (Glycine max (L.) Merrill) tem-se destacado nos últimos anos no Brasil, graças a uma alta nos preços do produto no mercado internacional, que ocorreu no início dos anos 70. Além das condições externas favoráveis, preços e demanda crescentes, o produto recebeu apoio governamental para sua disseminação (Bressan, 1997).

De origem asiática, a soja é a oleaginosa mais cultivada em todo o mundo, devido principalmente à sua ampla adaptação, incluindo-se atualmente regiões onde seu cultivo era limitado por problemas de fotoperíodo, além de seus subprodutos serem utilizados não só na alimentação humana, mas também como insumo na indústria de carnes e na composição de rações diversas.

Atualmente, os maiores produtores de soja são Estados Unidos, Brasil, Argentina e China, sendo que em cada país, o produto se desenvolveu de maneira diversa. No Brasil, o apoio recebido pela cultura da soja baseou-se no crédito rural subsidiado e numa política de preços mínimos, uma vez que o governo tinha interesse em diversificar a pauta de exportação (Bressan, 1997).

Com o apoio recebido, novas áreas foram incorporadas às regiões de cultivo. Além disso, por se tratar de um produto de exportação e por envolver 
uma significativa cadeia agroindustrial (farelo, óleo e grãos), exigiu-se um produto de alta qualidade.

De acordo com Roessing (1997), a previsão da safra mundial 1996/97, realizada pelo USDA, foi de 134 milhões de toneladas, 7,4\% acima da safra anterior. A produção de soja no Brasil deveria ser de $14 \%$ acima do volume produzido em 1995/96, devendo situar-se no patamar de 26,5 milhões de toneladas. Estas previsões foram precisas, pois de acordo com os dados do AGRIANUAL (1998) a produção mundial e brasileira foram de 131,6 e 26,5 milhões de toneladas, respectivamente. A previsão para a safra 1997/98, ao nivel mundial foi de 147,1 milhões de toneladas, sendo que para a safra brasileira espera-se cerca de 28,0 milhões de toneladas.

Tais avanços só foram possiveis pelo conhecimento e modificações dos mecanismos genéticos envolvidos na produtividade e adaptabilidade da soja, bem como de seus componentes. Neste sentido, os melhoristas de soja tiveram e têm função de destaque na obtenção de novos cultivares para elevar ainda mais os patamares de produtividade, para adaptar a cultura às novas áreas de cultivo, bem como para se obter um produto de melhor qualidade.

Nos programas de melhoramento maior ênfase têm sido dada aos caracteres relacionados à produtividade de grãos e ao fotoperíodo. Contudo, a ocorrência de pragas e doenças tem se tornado fator limitante da produção. Com isto existe uma tendência recente de se dar maior atenção à incorporação destas características de resistência, no sentido de torná-las também fatores estabilizadores da produtividade.

A utilização da resistência genética a insetos em cultivares de soja constitui-se numa estratégia alternativa, pois historicamente as infestações de pragas têm sido suprimidas pelo uso de produtos químicos. Apesar da importância destes produtos no controle de pragas em várias culturas, o uso da resistência surge como uma estratégia no mínimo complementar ao uso de inseticidas, por apresentar vantagens adicionais, como: maior equilíbrio 
ecológico, sem gastos adicionais para agricultores e desenvolvimento de tecnologia nacional.

A incorporação de resistência a insetos na cultura da soja é ainda pouco significativa, quando comparada com a obtenção de genótipos resistentes às principais doenças. Isto pode ser verificado pelo restrito número de cultivares lançados no Brasil e no mundo. No Brasil, existem apenas dois cultivares resistentes a insetos (sugadores e mastigadores), IAC-100 e IAC-17.

Este trabalho faz parte das linhas de pesquisa do Setor de Genética Aplicada às Espécies Autógamas, do Departamento de Genética da ESALQ/USP, e tem por objetivo a avaliação de populações de soja, com resistência a insetos, para caracteres agronômicos visando identificar genótipos que reunam características de alta produtividade, adaptação ao cultivo fora da época normal (verão) e resistência a percevejos. 


\section{Revisão de Literatura}

\subsection{Origem da soja e do germoplasma brasileiro}

A soja (Glycine max (L.) Merrill) é uma espécie autógama, com $2 n=40$ cromossomos, tendo sua origem no leste da Ásia, mais provavelmente no Centro de Origem Chinês. Segundo Hymowitz (1970), sua domesticação se deu por volta do século XI a.C. na região do centro-sul da China, próximo ao Rio Amarelo. Dessa região expandiu-se para outras regiões do país e para outros países asiáticos.

Na região da Manchúria, a cultura sofreu um grande desenvolvimento, tornando-se essa área um importante centro secundário de diversidade genética da espécie (Bonetti, 1981).

A soja foi introduzida na Europa no século XVIII e na América do Norte no início do século XIX (Bonato \& Dall'Agnoll,1985). A primeira menção nos EUA sobre a cultura da soja data de 1804 e referia-se ao cultivo desta na Pensilvânia (Bonetti, 1981) 
No Brasil, a primeira referência sobre a cultura da soja data de 1882 sobre sua introdução na Bahia. Em 1908, imigrantes japoneses introduziram a soja em São Paulo; somente em 1914 foi introduzida oficialmente no Rio Grande do Sul, onde foi iniciada a exploração econômica da cultura. Em 1949 realizou-se a primeira exportação brasileira de soja num total de 18.704 toneladas (Bonetti, 1981).

Atualmente, o Paraná é o maior produtor brasileiro, porém, a soja já é cultivada em quase todas as regiōes brasileiras, incluindo-se os Estados do Rio Grande do Sul, Maranhão, Bahia e Mato Grosso (Kiihl \& Almeida, 1992 e AGRIANUAL, 1998). Isto só foi possível graças aos programas de melhoramento genético.

Genótipos asiáticos introduzidos com posterior seleção constituem a base para o desenvolvimento da soja nos países produtores do ocidente. A introdução de materiais cultivados no Sul dos EUA, grupos de maturação de $V$ a $X$, foi o principal método de melhoramento no início do cultivo da soja no Brasil. Segundo Vello (1985), estes materiais são os que apresentavam maiores chances de adaptação às condições tropicais e subtropicais. Este autor relata ainda que, este fato tem sido muito bem explorado por melhoristas brasileiros.

Numa nova etapa, foram realizados cruzamentos biparentais, os quais originaram cultivares superiores, permitindo a exploração da cultura nas várias áreas do cerrado brasileiro (Kiihl \& Garcia, 1989; Spehar, 1994).

Os cruzamentos biparentais tiveram muito sucesso, tendo originado a maioria dos cerca de 200 cultivares de soja atualmente recomendados no Brasil. No entanto, a base genética estreita do germoplasma cultivado (11 linhagens ancestrais contribuindo com cerca de $90 \%$ do germoplasma, Hiromoto \& Vello, 1986), tem dificultado a obtenção recorrente de segregantes mais produtivos que os parentais e com resistência a doenças e pragas. 
Atualmente, cruzamentos múltiplos já estão sendo realizados com o objetivo de ampliar a base genética do germoplasma cultivado no Brasil, e ao mesmo tempo promover o desenvolvimento de novos cultivares (Vello, 1992b; Alliprandini, 1996 ; Lopes, 1996).

Os cruzamentos múltiplos vêm sendo usados, juntamente com proporções apropriadas de parentais exóticos, em programas de seleção recorrente, com a finalidade dupla de ampliar a base genética do germoplasma cultivado e, ao mesmo tempo, desenvolver novos cultivares.

\subsection{Resistência genética de soja a insetos}

A soja é atacada por diversas espécies de insetos, podendo ser destacados os percevejos sugadores de vagens Piezodorus güildinii, Nezara viridula e Euschistus heros (Rossetto et al., 1981b). Também podem se tornar pragas importantes alguns insetos mastigadores de folhas (mastigadores), como por exemplo, a largata Anticarsia gemmatalis (Rossetto et al., 1981b) e diversos coleópteros da familia Chrysomelidae, sendo os mais comuns Diabrotica speciosa (Massariol et al., 1979), Cerotoma arcuata (Rossetto et al., 1981c), Colaspis sp (Rossetto \& Nagai, 1980). Verifica-se ainda, a ocorrência de outros mastigadores causando danos na cultura da soja, como Diphaulaca viridipennis (Lourenção \& Miranda, 1986), Gynandrobrotica caviceps adumbrata (Pinheiro \& Vello, 1997) e Lagria villosa (Cividanes et al.,1996).

A característica de resistência genética a insetos, em cultivares de soja, é altamente desejável porque permite a minimização do uso de inseticidas, reduzindo consequentemente os custos da produção agrícola e os riscos de poluição ambiental. Apesar disto, dentre os cerca de 200 cultivares recomendados no Brasil, apenas IAC-100 e IAC-17 possuem resistência a insetos. Isto aconteceu porque, no período de cerca de 20 anos (anos 70 a 90) 
de cultivo comercial significativo da soja no país, os programas de melhoramento enfatizaram com muito sucesso outros caracteres como: produtividade de grãos, porte da planta, tolerância ao fotoperíodo e resistência a algumas doenças.

Com o cultivo sucessivo e com o aumento contínuo na área cultivada com soja no Brasil, vem ocorrendo também aumento na ocorrência de pragas nas lavouras, tornando necessário um incremento de investimentos em programas de melhoramento para resistência genética a pragas.

À semelhança dos principais caracteres agronômicos, na implementação de um programa de melhoramento eficiente, para resistência genética a pragas, 0 melhorista deve ter bons conhecimentos sobre as espécies e sobre as potencialidades genéticas do material a partir do qual vai efetuar o melhoramento. $O$ conhecimento da genética da resistência também é de grande valor em programas de melhoramento, por proporcionar uma base quantitativa para a recombinação, seleção e estabilidade contra a plasticidade genética da praga (Tingey, 1981).

Um objetivo prático e imediato no melhoramento visando plantas resistentes é a determinação do grau de controle proporcionado pela resistência aos insetos pragas. Num estágio inicial, deve-se concentrar 0 trabalho na identificação daquelas plantas que apresentam menor ataque e/ou dano. A determinação inicial é frequentemente feita no campo, com infestação natural, porque é necessário avaliar grandes populações de plantas. A seleção no campo também é desejável, pois a expressão e magnitude da resistência são sujeitas a modificações por fatores ambientais (Tingey, 1981).

Sabe-se, no entanto, que a avaliação da resistência em condições de campo apresenta uma grande limitação que é a ocorrência da praga em nível apropriado. Atualmente, dispõem-se de conhecimentos que permitem a manipulação externa para garantir uma infestação adequada. Entretanto, tornase oportuno a confirmação da resistência em condições de laboratório, quando 
possivel, após as seleções iniciais feitas no campo (Pinheiro, 1993). Deve-se aqui ressaltar as conclusões obtidas por Campo et al. (1986), onde os autores relatam que a dependência de ambientes artificiais para seleção pode levar a resultados diferentes daqueles obtidos em condições naturais. Deve-se considerar também que a multiplicação de pragas em laboratório tende a diminuir a sua agressividade.

Os conhecimentos de características específicas das plantas que condicionam a resistência são utilizados para entender a sua natureza genética, seu modo preciso de ação e contribuem para o aprimoramento dos métodos de seleção. Contudo, verifica-se que alguns cultivares já foram lançados mesmo não se conhecendo em detalhes a genética da resistência. Isto pode ser evidenciado pelo número de registros de linhagens resistentes a insetos nos EUA. Como exemplos recentes podem ser citadas as linhagens D86-3429 (Hartwig et al., 1994); D90-9216 e D90-9220 (Kilen \& Lambert, 1993); MC83-193 (Copper \& Hammond, 1995); MBB80-133, L86K-96 (Elden et al., 1992). Convém mencionar que estas linhagens são resistentes a insetos mastigadores, o que retrata a maior disponibilidade de materiais resistentes a estas pragas quando comparados com percevejos sugadores de vagens.

\subsubsection{Insetos sugadores}

Os sugadores que provocam danos em soja são os percevejos pentatomídeos. As espécies mais importantes no Brasil são: Piezodorus güildinii, Nezara viridula e Euschistus heros e recebem o nome de complexo de percevejos (Rossetto, 1989).

Segundo Kogan (1989), genótipos de soja resistentes a insetos sugadores, assim como mastigadores, têm sido identificados. Os niveis de resistência para cada grupo de insetos não são consideravelmente altos e um 
intenso programa de seleção torna-se necessário para identificar os genótipos superiores para uso em programas de melhoramento. Em muitos casos, a resistência é identificada em linhagens não adaptadas e com baixo valor agronômico, fato este que aumenta consideravelmente o tempo para incorporação da resistência em cultivares com boas caraterísticas. Deve-se, portanto, buscar como fontes de resistência materiais já adaptados para obtenção de resultados mais rápidos.

Os percevejos são considerados pragas importantes na cultura da soja por se alimentarem principalmente das partes reprodutivas, danificando diretamente suas vagens e sementes (Villas-Bôas et al., 1985 e Lourenção et al., 1987). Por esta razão, até mesmo uma baixa densidade de percevejos pode afetar a qualidade e produtividade da soja. De fato, diversos autores relatam que uma população composta por dois percevejos por metro linear é capaz de causar dano econômico na cultura da soja (Kogan et al., 1977; Panizzi et al.,1977 e Rossetto et al., 1984).

De acordo com Souza (1992), a colonização da soja por pentatomídeos tem seu início na pré-floração ( $R 2$ ), atingindo o máximo de infestação no final do período de granação ou enchimento das vagens (R7).

A extensão dos danos provocados pelos percevejos depende do estádio de desenvolvimento das vagens. Estas quando jovens são eliminadas pela planta após o ataque. Se estiverem na fase de granação, as sementes ficarão murchas ou deformadas. Além destes danos diretos, os percevejos podem ainda contribuir para a ocorrência da levedura Nematospora coryli nas puncturas de alimentação, ocasionando manchas escuras nas sementes. Isto afeta não só a qualidade das sementes mas também o valor comercial dos grãos (Kilpatrick \& Hartwig, 1955; Miranda et al., 1979; Gilman et al., 1980; Corso, 1984 e Panizzi \& Slansky, 1985). 
Os percevejos podem ainda transmitir doenças como o vírus do mosaico comum da soja ou transmitir outros microrganismos diretamente às plantas (Rossetto, 1989).

Uma consequência muito frequente do ataque de percevejos é a retenção foliar. Tem-se encontrado uma correlação positiva entre esta e o dano provocado nas vagens. A retenção foliar é caracterizada pela maturação desuniforme, ou seja, presença de hastes e folhas verdes, o que torna difícil a identificação do ponto de colheita (Rossetto et al., 1986). Entretanto, sabe-se que outros fatores também podem provocar a retenção foliar como o cultivo fora de época (Pinheiro, 1993), deficiência de potássio (Mascarenhas et al., 1988) e ausência de vagens na planta, como por exemplo nas plantas machoestéreis (Hicks \& Pendleton, 1969). Ainda hoje, os mecanismos que desencadeiam este fenômeno, ao nível bioquímico, não foram devidamente esclarecidos (Sosa-Gomes \& Moscardi, 1995). Ao se verificar o potencial das três principais espécies de percevejos (Piezodorus güildinii, Nezara viridula e Euschistus, heros ) em provocar a retenção foliar, estes autores concluíram que nas plantas atacadas com $P$. güildinii a ocorrência de retenção foi maior.

De acordo com Kogan (1989), a obtenção de resistência a insetos sugadores das vagens tem sido muito difícil. Vários cultivares e linhagens experimentais foram avaliados para as principais espécies de percevejos, tendo-se encontrado materiais menos suscetíveis. Segundo o autor, estes trabalhos têm sido feitos especialmente no Brasil.

As introduções PI 227687, PI 229358 e PI 171451 são consideradas as principais fontes de resistência a insetos (Turnipseed \& Sullivan, 1976); além delas, a PI 274454 (Rossetto et al., 1989) e a PI 171444 (Gilman et al.,1982) também são utilizadas como fonte de genes para resistência a percevejos.

Nos trabalhos desenvolvidos pelo Instituto Agronômico de Campinas visando a resistência de soja a percevejos, obteve-se sucesso com PI 227687 
e linhagens derivadas da PI 274454 (Rossetto et al., 1981b e 1989). Este programa de melhoramento lançou, em 1986, o cultivar IAC-100, cujo nome celebra o centenário desta instituição de pesquisa, sendo o primeiro material resistente aos principais insetos pragas já liberado para os agricultores.

$\mathrm{Na}$ avaliação da resistência é comum deparar-se com dados evidenciando que os cultivares mais precoces apresentam menos danos que os cultivares de ciclo médio e tardio. Esse fato deve ser interpretado com cautela, pois pode ser resultado de uma simples evasão hospedeira. Isto foi demonstrado por Jones Jr \& Sullivan (1978) e Link et al. (1982).

Diversos autores observaram que existe uma estreita correlação entre a duração do período reprodutivo e a intensidade dos danos causados por percevejos. Cultivares com período reprodutivo mais longo foram mais danificados (Daugherty et al., 1964; Link \& Costa, 1974 e Jones Jr \& Sullivan, 1978). A precocidade do ciclo da soja pode favorecer a evasão hospedeira (Painter, 1951), pois a planta precoce, passando mais rapidamente pelo período de maior suscetibilidade aos percevejos, deve sofrer menor dano que a planta tardia. Este mecanismo foi constatado por Rossetto et al. (1989) no cultivar IAC-100. Os autores relatam que o período de granação para este cultivar é menor, quando semeado em meados de novembro.

Geralmente os cultivares mais precoces que apresentam um curto período de granação, escapam do dano provocado pelos percevejos por maturarem antes que a população atinja um limite que cause dano econômico. Quando o periodo reprodutivo aumenta, normalmente, também aumenta o dano causado por percevejos (Miranda et al., 1979; Ferreira \& Panizzi, 1981; Gilman et al., 1982 e Lourenção et al., 1987).

A semeadura antecipada pode elevar o dano provocado pelos percevejos por aumentar o período de desenvolvimento das vagens, no qual a soja é mais suscetível. Isto deve-se a uma maior concentração de insetos nas plantas que entraram mais cedo no período reprodutivo (Jones \& Sullivan, 
1978 e Rossetto, 1989). Em áreas de cultivo onde se utilizam cultivares com diferentes ciclos, diferenças significativas são observadas quanto ao dano causado à cada um deles. Isto ocorre em virtude da migração dos percevejos das plantas maduras para aquelas que ainda estão verdes (Jones \& Sullivan, 1979).

$\mathrm{Na}$ resistência de soja a percevejos as plantas que produzem um grande número de vagens, com sementes pequenas, também são consideradas resistentes. De acordo com Miranda et al. (1979), seria desejável a obtenção de cultivares que apresentem grãos pequenos e alto teor de óleo, para se reduzirem os danos causados pelos percevejos. $O$ alto teor de óleo tem sido correlacionado positivamente com produtividade e com tamanho de grãos.

Nos estudos realizados por Link \& Estefanel (1982), verifica-se que os materiais com menor porcentagem de grãos danificados eram aqueles com sementes menores e, consequentemente com maior número de vagens por planta. Estes resultados também foram encontrados por Panizzi et al. (1986). Os autores concluíram que os materiais com sementes pequenas são resistentes por apresentarem grande número de grãos livres dos ataques de percevejos. Como o ataque diário dos percevejos é, em geral, constante, isto acaba resultando numa menor proporção de sementes atingidas (Rossetto, 1989). Este autor relata ainda que o cultivar IAC-100 apresenta esta característica. Este mecanismo de resistência foi definido por Rossetto \& Lara (1991) como sendo o de diluição de dano. Nos trabalhos realizados por Pinheiro et al. (1997) verificou-se a presença do mecanismo de diluição de danos no cultivar IAC-100 e em cruzamentos envolvendo este parental.

Rossetto et al. (1995) discutiram os mecanismos de resistência ao complexo de percevejos envolvidos no cultivar IAC-100. Estes autores relatam que pelo menos cinco mecanismos estão envolvidos, sendo: menor período de granação; maior número de sementes; rejeição de vagens novas atacadas, 
com sua rápida substituição; senescência normal com queda das folhas na maturação; e resistência à levedura (Nematospora coryli) transmitida pelos percevejos.

Jones \& Sullivan (1979), em trabalhos visando a resistência a percevejos, observaram que as Pl's 227687, 229358 e 171451 expressam efeitos antibióticos sobre as ninfas de Nezara viridula e não preferência para alimentação.

Segundo Kester et al. (1984), o mecanismo da resistência da PI 171444 a $N$. viridula deve-se à existência de não preferência, antibiose e evasão hospedeira. A não preferência para alimentação também foi verificada por Rossetto et al. (1981a) nas linhagens IAC73-228 e IAC77-656. Este estudo foi realizado em condições de casa-de-vegetação.

De acordo com as pesquisas de Rossetto et al. (1981a), a retenção foliar provocada pelo ataque de percevejos, provavelmente é uma característica de herança simples, governada por poucos genes. Em relato posterior, Rossetto (1989) conclui que no controle genético estão envolvidos um ou dois genes dominantes com efeitos epistáticos sobre um gene inibidor da resistência. Este estudo foi feito a partir do cruzamento da linhagem resistente IAC73-228 e o cultivar Paraná.

Nos trabalhos de Souza (1992) e Souza \& Toledo (1995), onde se avaliaram os mecanismos genéticos para a retenção foliar e porcentagem de sementes sadias, em cruzamentos envolvendo as linhagens resistentes IAC742832 e IAC78-2318 e os cultivares Davis, BR-13 e Lancer, os autores verificaram a presença de efeitos aditivos, de dominância e epistáticos.

Entretanto, para Kogan (1989), os estudos genéticos para determinar o número de genes envolvidos na resistência da soja a insetos, não têm fornecido informações muito precisas. $O$ pouco conhecimento da genética da resistência, juntamente com o efeito aparentemente pleiotrópico dos genes de resistência em alguns fatores ligados à produtividade, têm levado a 
divergências frequentes entre produtividade e resistência em progênies de cruzamentos envolvendo Pl's e cultivares elite.

\subsubsection{Insetos Mastigadores}

De acordo com Bonato (1986), são várias as espécies de insetos mastigadores que atacam a soja. No Brasil as mais comuns são: a lagarta da soja (Anticarsia gemmatalis), lagarta falsa medideira (Pseudoplusia includens), lagarta enroladeira (Hedylepta indicata) e lagarta das vagens (Spodoptera eridania). Além das lagartas, alguns coleópteros também podem provocar danos consideráveis em lavouras da soja, sendo os principais Cerotoma arcuata, Diabrotica speciosa e Colaspis sp. (Rossetto et al., 1981b).

As introduções PI 171451 ('Kosamame'), PI 229358 ('Sodendaizu') e PI 227687 ('Miyako White') são consideradas como fonte de resistência a partir das quais se iniciaram os trabalhos de melhoramento (Van Duyn et al., 1971). Estas PI's têm sido identificadas como sendo resistentes a diferentes espécies de insetos mastigadores como: Anticarsia gemmatalis, Trichoplusia ni, Pseudoplusia includens, Helicoverpa zea, Heliothis virescens, Heliothis armigera, Heliothis puctigera, Hedilepta indicata, Epinotia aporema, Spodoptera exigua, Plusia sp., Cerotoma arcuata, Cerotoma trifurcata, Diabrotica speciosa, Diabrotica balteata, Colaspis occidentalis, Epilachna varivestis, Epicauta vittata, Andrector hybridus, Anomala cupripes, Porthesia taiwana, Popillia japonica e Orgyia sp. (Van Duyn et al., 1971 e 1972; Clark et al.,1972; Elden et al., 1974; Hatchett et al., 1976; Turnipseed \& Sullivan, 1976; Luedders \& Dickerson, 1977; Kilen et al., 1977; Link \& Costa, 1978; Tuart \& Rose, 1979; Pascal II \& Rogers, 1979; Smith \& Brim, 1979; Rossetto \& Nagai, 1980; Castro, 1981; Smith \& Gilman, 1981; Rossetto et al., 1981(c); Link \& Costa, 1981a; Lourenção \& Miranda, 1983; Lambert \& Kilen, 1984(a); Sullivan, 1985; Smith, 
1985; Lourenção et al., 1985; Kilen \& Lambert, 1986; Rufener et al., 1986; Layton et al., 1987; AVRDC, 1987; Talekar et al., 1988; All et al., 1989; Hammond \& Cooper, 1989; Lourenção et al., 1989).

Estas introduções de plantas foram utilizadas como fonte de genes, originaram diversas linhagens e, posteriormente, alguns cultivares resistentes. Estes materiais apresentam resistência múltipla, ou seja, são resistentes a um grande número de pragas. De acordo com Miranda et al. (1987), isto se deve a existência de supergenes. A presença de resistência múltipla aos insetos é importante, pois a ocorrência de pragas varia na área de produção, bem como nos anos (Hartwig \& Kilen, 1989)

A existência de supergenes para a resistência múltipla às pragas, pode dinamizar o programa de melhoramento, pois facilita a transferência rápida dos genes de resistência e não implica na criação sistemática de todas as pragas, podendo-se trabalhar com as que ocorrerem no campo. Segundo Lourenção \& Miranda (1987) e Lourenção et al. (1997), a linhagem IAC 782318 apresenta resistência múltipla a insetos.

Nos estudos de Hatchett et al. (1979) a partir do cruzamento PI 229358 x Bragg, os autores verificaram a existência de multiresistência, uma vez que as linhagens obtidas mostraram-se resistentes a Pseudoplusia includens, Helicoverpa zea, Heliothis virescens e Epilachna varivestis. Contudo, observaram também que o grau de resistência pode variar de acordo com a espécie de inseto estudada.

A resistência múltipla já havia sido relatada por Turnipseed \& Kogan (1976) nas Pl's 229358 e 171451, sendo que os trabalhos de Lambert \& Kilen (1984c) e Hatchett et al. (1979) confirmaram o comportamento da PI 229358. Os trabalhos de Hatchett et al. (1979) relatam que o nivel de resistência, observado em todas as linhagens desenvolvidas a partir do cruzamento da PI 229358 x Bragg, a Helicoverpa zea e Pseudoplusia includens sugeriram que os 
genes que condicionam a resistência a estas espécies poderiam ser os mesmos ou estarem proximamente ligados.

Segundo Porto (1983) e Hartwig \& Kilen (1989), o germoplasma de soja foi selecionado para resistência ao besouro mexicano (Epilachna varivestis) por Van Duyn e colaboradores, em 1967, na Carolina do Norte e em 1968 na Carolina do Sul. Estes pesquisadores identificaram as Pl's 229358, 171451 e 227687 como sendo altamente resistentes a esta praga. A partir destas fontes de resistência tiveram início alguns programas de melhoramento, como o do Dr. Edgard E. Hartwig, melhorista de soja do Departamento de Agricultura dos Estados Unidos, no Delta Mississippi, que usa a PI 229358 em cruzamento com o cultivar Bragg. Esta introdução (PI) apresenta características agronômicas mais desejáveis quando comparada com as Pl's 227687 e 171451 (Lambert \& Kilen, 1984b).

Como exemplo de cultivares resistentes a insetos mastigadores liberados, cujas fontes de resistência são as Pl's 229358, 227687 e 171451, podem-se mencionar Crockett, Lamar, IAC-100 e IAC-17.

O cultivar Crockett é uma seleção do cruzamento da PI 171451 X Hampton 266A e apresenta alto nível de resistência à lagarta da soja (Anticarsia gemmatalis) e à lagarta falsa medideira (Pseudoplusia includens), além de resistência a algumas doenças como a mancha olho de rã (Cercospora sojina) e cancro da haste (Diaporthe phaseolorum var. caulivora) (Bowers Jr., 1990).

O cultivar Lamar é uma seleção do cruzamento entre Tracy $M X$ Progênie $F_{2}$ (Centennial $X$ D75-10169). Este cultivar tem demonstrado boa resistência à lagarta falsa medideira e à lagarta da soja, tanto em condições de telado como no campo (Hartwig \& Kilen, 1989 e Hartwig et al., 1990).

Além desses cultivares norte americanos o cultivar IAC-100 foi liberado em fevereiro de 1989 para o Estado de São Paulo e apresenta boa 
resistência aos principais insetos mastigadores e ao complexo de percevejos. Sua resistência é derivada das Pl's 229358 e 274454 (Rossetto, 1989).

As plantas de soja podem apresentar diversos mecanismos de resistência aos insetos mastigadores, sendo os mais comuns: antibiose (Kogan, 1972 e Hatchett et al., 1976), não preferência para alimentação (Clark et al.,1972; Kogan, 1972 e Oliveira et al., 1984) e não preferência para oviposição (Clark et al., 1972).

A antibiose tem sido relatada como o principal mecanismo de resistência das Pl's 229358, 171451 e 227687 aos insetos mastigadores. Este tipo de resistência, segundo Painter (1951), prococa uma menor taxa de crescimento, maior mortalidade e menor fertilidade, entre outros. Isto faz com que a população de insetos no campo a cada ciclo seja menor, pois este ciclo será maior. Consequentemente, os insetos ficam mais tempo expostos aos inimigos naturais e a outras medidas de controle.

Não se tem relato de características morfológicas como causa de resistência aos insetos mastigadores em soja (Lambert \& Kilen, 1984c, Talekar et al., 1988 e Hartwig \& Kilen, 1989).

Os diversos estudos sobre os tipos de mecanismos envolvidos na resistência a insetos mastigadores foram feitos principalmente com o besouro mexicano. De acordo com Van Duyn et al. (1971), a resistência das Pl's 229358, 227687 e 171451, a Epilachna varivestis é causada pela não preferência e antibiose. Observou-se, neste estudo, uma redução na alimentação e também redução do crescimento, sobrevivência, oviposição e fecundidade do inseto. Kogan (1972) também relata a não preferência desta praga pelas PI's 229385 e 171451.

Nos trabalhos de Rufener et al. (1986 e 1987), as Pl's 229358, 171451 e 227687 e as linhagens derivadas destes materiais, provocaram redução na fecundidade e longevidade, sendo que as folhas dos genótipos 
resistentes foram menos aceitas para alimentação até mesmo quando representavam a única fonte de alimento.

Hammond \& Cooper (1989) demonstraram que a resistência a Epilachna varivestis presente em linhagens derivadas do cruzamento PI 229358 X Pixie, é do tipo antibiose e o grau de resistência, semelhante ao encontrado na PI.

Este tipo de resistência também é encontrado em materiais que não têm como fonte de genes as Pl's mais utilizadas. Smith et al. (1975) relatam que o cultivar Shore apresenta alto grau de resistência ao besouro mexicano, sendo também do tipo de não preferência e antibiose. O cultivar Shore é uma seleção do cruzamento PI 80837 X Hood.

A resistência genética da soja também tem sido avaliada por diversos autores em relação a outros insetos mastigadores. Clark et al. (1972), estudando as Pl's 227687, 171451 e 229358 para resistência a Helicoverpa zea, relatam que a PI 171451 apresentou a mais baixa oviposição, sendo a mais alta verificada na PI 227687. Contudo, o menor dano foi verificado na segunda $\mathrm{PI}$, sugerindo antibiose para lagartas.

Beland \& Hatchett (1976) relatam a presença de antibiose como mecanismo de resistência de soja a Helicoverpa zea. Os autores sugerem que a inadequação alimentar, além de prolongar o ciclo pode causar outros distúrbios fisiológicos. Este comportamento também é relatado por Hatchett et al. (1976) para resistência de soja a Helicoverpa zea e Heliothis virescens, representada pela alta mortalidade de lagartas, mudas de pele adicionais, redução do peso e da longevidade do inseto.

Smith (1985) descreve, em seus estudos, como sendo antibiose e não preferência para alimentação, os tipos de resistência presentes na PI 227687 em relação a Pseudoplusia includens.

Nas pesquisas de Beach et al. (1985) para verificar a resistência de linhagens derivadas da PI 229358 a $P$. includens notaram que além de haver 
menor consumo de suas folhas, houve também nesses genótipos maior mortalidade, um maior número de dias para a pupação e menor oviposição.

Para Beach \& Todd (1987), a não preferência associada à antibiose é responsável pela resistência da linhagem GatIR-81-296 a Spodoptera frugiperda, Spodoptera ornithogalli e Spodoptera eridania.

A resistência da soja às espécies de Heliothis é expressa como antixenose (não-preferência) para oviposição das fêmeas e antibiose para lagarta que é mastigadora (Paschal II \& Rogers, 1979).

Em relação à lagarta da soja (Anticarsia gemmatalis) a não preferência foi relatada por Castiglione-Rosales (1990) e Hoffman-Campo et al. (1994), nas Pl's 171451 e 229358.

No estudo de Castigilioni \& Vendramim (1996), os autores concluem que o cultivar IAC-100 reduziu o peso de pupas e a PI 229390 alongou a fase imatura e reduziu o peso de lagartas. Ainda em relação a IAC-100, Oliveira et al. (1993) também verificaram que este cultivar provocou aumento no tempo de desenvolvimento e redução no peso para $A$. gemmatalis. Tais resultados indicam a presença de antibiose.

Gazzoni \& Tutida (1996), estudando o comportamento de quatro cultivares resistentes a insetos e duas linhagens, verificaram que o cultivar Crockett foi o que mais afetou negativamente a biologia da lagarta da soja, por propiciar baixos indices de ganho de peso, peso de pupas e maior mortalidade. Este comportamento demonstra a presença de antibiose. Os demais genótipos (os cultivares IAC-100, IAC-17 e Lamar; as linhagens BT92-10644 e BT 921086) também apresentaram efeitos negativos sobre o desenvolvimento de $A$. gemmatalis.

A herança da resistência às pragas mastigadoras (desfolhadoras) não é totalmente conhecida. Há indicações de que a herança seja quantitativa, porém, com pequeno número de genes envolvidos, talvez dois ou três, segundo Sisson et al. (1976). Estes autores estudaram a desfolha provocada 
por Epilachna varivestis, em linhagens derivadas de cruzamentos envolvendo as Pl's 229358, 227687 e 229321, e encontraram uma considerável variância genética. Neste estudo a herdabilidade no sentido amplo variou de $43,8 \%$ a 80,6\%, sendo que a maior foi observada na população oriunda da PI 229358. Os autores não eliminaram a existência de dominância ou de efeitos epistáticos.

Ao estudar plantas da geração F1 de cruzamentos envolvendo as Pl's 229358, 171451 e 227687, Kogan (1972) verificou a presença de dominância parcial para a resistência a Epilachna varivestis.

Rufener (1988) e Rufener et al. (1989) estudaram a genética da resistência ao besouro mexicano em híbridos de retrocruzamento de três linhagens resistentes (L76-0049, 178-608, com resistência derivada da PI 171451 e L76-0328, com resistência derivada da PI 229358), e relataram que as médias das populações não foram significativamente diferentes do valor médio dos parentais. Isto indica a ausência de dominância nos cruzamentos envolvendo L78-0049 e L76-608. No cruzamento envolvendo a linhagem L760328 verificou-se a presença de dominância incompleta. Estes autores mencionam, ainda, ser pequeno o número de genes envolvidos na resistência, uma vez que o fenótipo dos parentais foi frequentemente recuperado nas gerações $F_{2}$ e $F_{3}$.

Outros estudos sobre a genética da resistência em soja para o besouro mexicano foram feitos por Mebrahtu et al.(1990), que avaliaram progênies $F_{3}$ do cruzamento entre a linhagem MBB80-115 e o cultivar Ware. Os autores relatam que a variabilidade genética variou de moderada (21 a 40\% de desfolha) a alta resistência ( 0 a $20 \%$ de desfolha), sendo o dano médio semelhante ao valor dos parentais. A herdabilidade encontrada no sentido amplo foi de $43 \%$ e o progresso genético de $15 \%$. Para estas estimativas utilizou-se a porcentagem de seleção de $10 \%$. 
Kilen et al. (1977), avaliando as gerações $F_{1}, F_{2}$ e $F_{3}$ do cruzamento envolvendo a PI 229358 e o cultivar Davis, verificaram que não existe dominância para a resistência a Pseudoplusia includens na geração $F_{1}$. Entretanto, a geração $F_{2}$ apresentou assimetria em relação ao parental suscetivel, sugerindo dominância parcial para suscetibilidade, que seria governada por poucos genes.

Avaliando a resistência a Trichoplusia ni de populações originadas dos cruzamentos PI $229358 \times$ Beeson, PI 171451 X Beeson, PI $229358 \times$ Amsoy 71 e PI 117451 X Amsoy 71 , em condições de campo, Luedders \& Dickerson (1977) encontraram herdabilidades de $6 \%, 18 \%, 37 \%$ e $44 \%$, respectivamente.

Num estudo do comportamento da resistência a Colaspis occidentalis e Diabrotica speciosa, nos cruzamentos entre a PI 227687 e os cultivares Santa Rosa e Paraná, Rezende et al. (1980b) obtiveram, na geração $F_{1}$, uma resposta similar a da PI e concluíram que efeitos de dominância estavam presentes.

Lourenção et al. (1985) observaram que em condições de campo, sob o ataque da lagarta enroladeira (Hedilepta indicata), a PI 227687 foi a que sofreu a menor desfolha. Estes autores relatam ainda que a geração $F_{2}$ obtida do cruzamento entre PI 274453, considerada resistente a insetos mastigadores, e o cultivar Paraná indicou a presença de um alelo dominante para resistência a esta praga.

Nos trabalhos de Kilen \& Lambert (1986), envolvendo cruzamentos entre as Pl's 229358, 227687 e 171451, avaliou-se o dano provocado pela lagarta da soja nestas Pl's e em seus descendentes na geração $F_{3}$. Esta avaliação foi realizada em condições de campo e casa-de-vegetação, tendo sido encontrada uma distribuição normal para os danos de acordo com as categorias estabelecidas. Este comportamento indica uma herança quantitativa. Entretanto, verificou-se um grande número de progênies $F_{3}$ 
apresentando dano superior ao dos parentais, o que sugere a presença de um pequeno número de genes controlando a resistência. Segundo os autores, esta resistência é controlada por diferentes genes nas Pl's, pois verificou-se também algumas progênies $F_{3}$ com danos menores que os parentais, sugerindo novas combinações gênicas fornecendo um nivel de resistência superior ao dos parentais.

\subsection{Caracteres agronômicos}

Os resultados obtidos no melhoramento de plantas autógamas, basicamente envolveram hibridação de um pequeno número de genótipos, seguida de um dos processos de avanço de gerações segregantes até a obtenção de genótipos homozigóticos e, finalmente, os testes de produtividade e desempenho agronômico.

O conhecimento das ações gênicas envolvidas é fundamental para a tomada de decisão sobre o melhor método de melhoramento e seleção (Sprague, 1966). Isto permitiu um progresso muito eficiente, quando os trabalhos foram realizados com caracteres qualitativos e que apresentam alta herdabilidade. Para os caracteres quantitativos, como por exemplo a produtividade de grãos que apresenta baixa herdabilidade, os progressos obtidos pelos métodos tradicionais de melhoramento não foram tão acentuados. De acordo com Brim (1973), isto ocorre com a soja, para a qual os progressos observados com a seleção são geralmente pequenos. 


\subsubsection{Produtividade de grãos}

A produtividade de grãos em soja é um caráter essencialmente quantitativo, sendo que a variância genética aditiva e a variância devida à epistasia do tipo aditiva $\mathrm{x}$ aditiva $(\mathrm{A} \times \mathrm{A})$ têm sido os principais componentes (St Martin, 1984). Diversos autores, empregando diferentes métodos, constataram este fato, entre eles: (a) cruzamentos e autofecundações sucessivas (Brim \& Cockerham, 1961); (b) cruzamentos dialélicos completos e parciais (Paschal II \& Wilcox, 1975; Toledo \& Kiihl, 1982b; Freire Filho, 1988 e Pinheiro, 1993); (c) esquema fatorial - delineamento II de Comstock \& Robinson (Cecon et al., 1985) e (d) topocruzamentos (Destro, 1991; Pacova, 1992).

Nos programas de melhoramento genético, embora o aumento da produtividade tenha sido buscado, na cultura da soja, o progresso genético diminuiu desde a época em que se iniciou a obtenção de cultivares por hibridação (Fehr, 1987).

A dificuldade em superar os progressos genéticos já obtidos com os novos cultivares foi observada por Luedders (1977). Este autor relata que o primeiro ciclo de cultivares, a partir de hibridações, proporcionou um maior ganho na produtividade do que os dos ciclos subsequentes.

Segundo Toledo et al. (1990), uma vez atingida uma alta produtividade, torna-se difícil incrementar ganhos com a mesma velocidade, devido à multiplicidade de objetivos a serem atingidos para substituir os cultivares bem adaptados.

A diversidade genética é, sem dúvida, um dos fatores que têm contribuído para a não superação dos patamares de produtividade na cultura da soja. Assim, é cada vez maior a dificuldade de se identificarem em genótipos altamente produtivos que não tenham ancestrais comuns. Os estudos de St. Martin (1982) relatam que o melhoramento de soja promoveu um 
aumento substancial na produtividade, porém, com uma considerável redução da variabilidade genética. A base genética estreita foi constatada no germoplasma cultivado brasileiro, por Hiromoto e Vello (1986), sendo que apenas 11 ancestrais contribuíram com $89 \%$ do conjunto gênico destes genótipos.

Uma estratégia que combina a preservação, ampliação e uso de germoplasma, com o objetivo de associar a síntese de populações com base genética ampla, é a seleção recorrente (Vello, 1992a). O emprego desta metodologia nos programas de melhoramento de soja, foi sugerido por Hanson et al. (1967), para contornar os insucessos que vinham ocorrendo devido à baixa frequência de novas recombinaçōes gênicas. Vários programas têm usado a seleção recorrente com bons resultados no aumento da produtividade (Kenworthy \& Brim, 1979; Sumarno \& Fehr, 1982; Werner \& Wilcox, 1990; Fatmi et al., 1992, Rose et al., 1992; e Burton \& Carver, 1993).

A utilização de cruzamentos múltiplos para aumentar a variabilidade (Uneda-Trevisoli \& Vello, 1997) também tem proporcionado um aumento no ganho genético para diversos caracteres. Os trabalhos de Lopes (1996) e Alliprandini (1996) revelam a identificação de segregantes superiores para produtividade de grãos.

De acordo com Toledo et al. (1990), a utilização dos conhecimentos de genética quantitativa para avaliar o desempenho dos materiais nas várias etapas de um programa de melhoramento, deverá proporcionar um aumento no progresso até então obtido.

Para Ramalho \& Vencovsky (1978) o desenvolvimento de um método mais eficiente de melhoramento depende de um maior conhecimento da variabilidade genética e do tipo de ação gênica predominante no controle do caráter sob seleção.

Para as espécies autógamas, o ideal é que a variância genética predominante seja devida principalmente aos efeitos aditivos dos genes, de 
cuja magnitude depende o sucesso da seleção. Isto porque a exploração de heterose, em culturas como a soja, ainda não é viável.

Diversos trabalhos em soja têm mostrado que a variância aditiva e a variância da epistasia aditiva $x$ aditiva $(A \times A)$ são os componentes principais da variância genética (Horner \& Weber, 1956; Leffel \& Weiss, 1958; Gates et al., 1960; Brim \& Cockerham, 1961; Croissant \& Tornie, 1971; Singh et al., 1974; Bhatade et al., 1977; Cecon et al., 1985; Freire Filho, 1988; Nass, 1989; Bonato, 1989; Destro, 1991 e Pinheiro, 1993).

Esta evidência é muito importante para o melhoramento de espécies autógamas, pois a média das gerações não se altera e as combinações gênicas são realmente transmitidas ao longo das gerações. Isto permite que se realizem testes precoces e seleção em vários níveis de endogamia (Brim \& Cockerham, 1961).

Convém ressaltar a observação, por diferentes autores, de variância de dominância, no estudo de caracteres quantitativos, superiores as aditivas (Leffel \& Weiss, 1958; Brim \& Cockerham, 1961; Leffel \& Hanson, 1961; Camacho, 1971 e Pacova, 1992).

Um outro fator importante na herança de caracteres quantitativos, como produtividade de grãos, é a presença de epistasia (St. Martin, 1981). De acordo com Hanson \& Weber (1961 e 1962) e Hanson et al. (1967), 70\% da variância genética para produtividade de grãos foi atribuida à epistasia. Isto implica que a seleção para este caráter, em soja, é mais eficiente nas gerações avançadas, onde esta epistasia é capitalizada. A epistasia $A \times A$ não se manifesta nas gerações iniciais de endogamia, contudo, este componente não pode ser transmitido via cruzamento, apesar de ser explorado com a seleção (St. Martin, 1981 e 1985). Isto ocorre porque seu efeito está associado à combinação de alelos de locos gênicos diferentes, sendo este, sujeito a modificação durante as autofecundações e recombinações. 


\subsubsection{Período Juvenil Longo}

A introdução de genes para período juvenil longo (PJL) tem sido sugerida como uma das alternativas viáveis para solucionar a grande sensibilidade de cultivares de soja ao fotoperíodo. Isto porque o PJL é um caráter relativamente simples, envolvendo poucos genes recessivos e tem importância fundamental na adaptação da soja às condições ambientais das regiões de baixa latitude $\left(<15^{\circ}\right)$ e cultivos fora da época padrão, que no hemisfério sul é novembro (Hinson, 1989 e Kiihl \& Garcia, 1989).

De acordo com Destro (1991), o período vegetativo compreende o número de dias entre a emergência da planta até o aparecimento da primeira flor, sendo subdividido em período juvenil e período indutivo. O período juvenil compreende a fase do desenvolvimento inicial da planta, na qual esta é insensivel ou neutra às condições fotoperiódicas favoráveis à indução do florescimento.

Criswell \& Hume (1972) conduziram experimentos para a identificação de genótipos de soja insensiveis ao fotoperíodo, com o objetivo de utilizá-los como parentais em programas de melhoramento. Os autores observaram que os cultivares mais precoces foram menos sensiveis que os tardios.

Os trabalhos conduzidos por Shanmugasundaram \& Tsou (1978) com linhagens de soja sensiveis e insensiveis ao fotoperíodo, permitiu aos autores concluírem que o tempo crítico para a indução floral foi de nove dias após a emergência, no genótipo sensivel. Para isto, os materiais foram conduzidos em casa-de-vegetação com alternância diária do fotoperíodo de 10 horas para 16 horas, bem como o contrário.

O controle genético do tempo para o florescimento e a maturidade em soja, sob condições de dias curtos, é diferente daquele verificado em condições de dias longos. Ocorre uma alteração nestes períodos com a 
mudança nas condições de cultivo de regiões com dias curtos para aqueles com dias longos, comuns em regiões com maior latitude. Os estudos realizados por Kiihl (1976), Hartwig \& Kiihl (1979), Tisselli Filho (1981) e Toledo \& Kiihl (1982a) constataram que o florescimento tardio é controlado por genes recessivos, em condições de dias curtos.

Este resultado também foi encontrado por Gilioli et al. (1984) ao estudar quatro mutantes e os cultivares que lhes originaram, sob dois fotoperíodos diferentes. O primeiro representando dias curtos $(10,56 \mathrm{~h})$ e o segundo dias longos $(13,21 \mathrm{~h})$. Este estudo foi realizado numa região com $20^{\circ} 45^{\prime}$ de latitude sul e seus autores concluíram que existe um alelo dominante determinando o florescimento e a maturidade precoce em ambos os fotoperíodos.

Bonato (1989), avaliando a maturidade sob condições de dias curtos, propõe os genótipos referentes ao controle genético deste caráter, sendo que este é diretamente relacionado com o florescimento; os cultivares presentes no estudo teriam os seguintes genótipos: (a) Paraná = Es1/Es1 Es2/Es2, (b) Paranagoiana $=$ es1a/es1a Es2/Es2, (c) SS1 = es1b/es1b Es2/Es2 e (d) Pirapó = Es1/Es1 es2/es2.

Em trabalhos realizados sob condições de dias longos, foram identificados cinco pares de alelos independentes: E1/e1 e E2/e2 (Bernard, 1971), E3/e3 (Buzzell, 1971), E4/e4 (Buzzell \& Voldeng, 1980) e Es/es (McBlain 1985 e MacBlain e Bernard, 1987). Os alelos dominantes determinam o florescimento e a maturidade tardios.

\subsubsection{Altura da planta e valor agronômico}

A herança da altura da planta, como para os caracteres período reprodutivo e produtividade de grãos, é, em geral, de natureza quantitativa. 0 
valor agronômico tem sido um caráter pouco estudado, talvez, devido à subjetividade de sua avaliação, pois corresponde a uma combinação de vários caracteres e, em geral, é avaliado visualmente por uma única pessoa por experimento. Entretanto, os resultados obtidos por Caviness \& Prongsirivathana (1968) mostraram que um gene principal e outros menores, condicionaram este caráter. De acordo com Freire Filho (1988), o controle genético da altura da planta no florescimento parece ser diferente daquele verificado para altura da planta na maturidade.

\subsection{Estimativas de parâmetros genéticos}

As estimativas de parâmetros genotípicos e fenotípicos são ferramentas de grande importância para a tomada de decisões quanto ao método de melhoramento a ser utilizado, da maneira de condução e de seleção das populações segregantes. Desta forma, torna-se possivel aos melhoristas anteverem as possibilidades de sucesso nos programas de melhoramento (Ramalho et al., 1993).

Entre os parâmetros mais importantes estão o coeficiente de herdabilidade, a correlação entre caracteres, o ganho de seleção e o coeficiente de variação genética, entre outros. Estas estimativas são de maior valor quando baseadas na avaliação de genótipos em diferentes ambientes como locais e anos (Kwon \& Tornie, 1964).

\subsubsection{Correlação entre caracteres}

De acordo com Vencovsky \& Barriga (1992), o estudo da natureza e magnitude da associação existente entre os diferentes caracteres de uma 
cultura em muito pode contribuir para o melhoramento genético. 0 conhecimento das estimativas das correlações entre caracteres torna-se importante, tanto no planejamento quanto na avaliação de programas de melhoramento, pois torna-se importante saber como a seleção em um caráter pode causar alterações em outro. Isto reflete a preocupação em se aprimorar o material não para caracteres isolados, mas simultaneamente para um conjunto deles.

Segundo Wright (1921), o coeficiente de correlação assume que há uma relação linear entre duas variáveis, ou seja, que a mudança em uma variável sempre envolve uma alteração aproximadamente constante no valor médio da outra variável.

A correlação mensurada a partir de dois caracteres num certo número de indivíduos da população é a fenotípica. Esta tem causas genéticas e ambientais, sendo que no melhoramento a associação de maior importância é a genética, ou seja, devido a sua natureza herdável (Vencovsky \& Barriga, 1992).

A principal causa da correlação genética é a pleiotropia, uma vez que a ligação gênica é transitória, principalmente em populações obtidas a partir do cruzamento entre parentais divergentes. A correlação genética devida à ligação é desfeita quando a população atinge o equilíbrio de ligação (Falconer, 1989).

Quando a correlação genética entre dois caracteres for positiva, isto indica que é possível obterem-se ganhos para um deles como uma resposta indireta à seleção praticada sobre o outro. Segundo Cruz \& Regazzi (1994), a seleção indireta com base na resposta correlacionada, pode conduzir a progressos mais rápidos no melhoramento. A partir da resposta correlacionada à seleção pode-se indagar em quanto será alterada a média do caráter $Y$ ao se fazer a seleção no caráter $X$ (Vencovsky \& Barriga, 1992). Convém ressaltar os 
resultados de Byth et al. (1969), cujos relatos revelam que a seleção indireta para produtividade não é tão eficiente.

Em geral, os coeficientes de correlação genética e ambiental apresentam o mesmo sinal. Entretanto, quando isso não ocorre, existe um indicativo de que as causas da variação genética e ambiental influenciam os caracteres por meio de mecanismos fisiológicos diferentes (Falconer, 1989).

Uma estimativa negativa de correlação genética, envolvendo caracteres que devem ser selecionados num mesmo sentido na população, implica em problemas na seleção conjunta para os caracteres em questão. Isto porque a seleção para aumento em um caráter resultará numa diminuição no outro caráter (Silva, 1982).

$\mathrm{Na}$ cultura da soja, apesar da variabilidade, tem-se verificado que, geralmente, a produtividade de grãos está associada positivamente à altura da planta na maturidade e ao número de dias para a maturidade. A magnitude destas correlações genotípicas é, na maioria dos casos maior que 0,40 , podendo ser classificada como média a alta. Isto indica uma certa dificuldade em selecionar plantas precoces e produtivas (Montaño-Velasco, 1994; Montenegro, 1994; Santos et al., 1995; Farias Neto, 1995 e Gomes, 1995).

Verifica-se também uma predominância de correlações genotípicas positivas entre a altura da planta e o número de dias para a maturidade (Cecon et al. 1993; Santos, 1994).

O teor de proteínas está associado alta e negativamente com o teor de óleo e com a produtividade de grãos (Montaño-Velasco, 1994; Farias Neto, 1995).

Os caracteres relacionados com a resistência a insetos como porcentagem de retenção foliar (PRF) e porcentagem de sementes manchadas (PSM), provocados pelo ataque de percevejos, na soja, são negativamente correlacionados com a produtividade de grãos, com magnitude ao redor de 0,7 (Pinheiro, 1993). 
Revisões relativamente completas sobre a correlação entre caracteres na cultura da soja podem ser encontradas em Gomes (1995) e Laínez-Mejía (1996).

Pelo exposto verifica-se que há uma grande variação entre caracteres em direção e, principalmente, em magnitude entre diferentes populações. Contudo, com as estimativas disponiveis para as mais variadas associações, já se dispõem de informações básicas para orientar os programas de melhoramento. Deve-se considerar ainda que as correlações variam entre as diferentes populações de plantas de uma mesma espécie, fato este que torna recomendável, sempre que possível, a estimação da correlação para cada população, visando-se obter maior eficiência na seleção.

\subsubsection{Capacidade de combinação}

A seleção de parentais em um programa de melhoramento é fundamental, uma vez que o sucesso do programa depende diretamente desta etapa inicial. Várias metodologias têm sido propostas para auxiliar o melhorista na escolha de parentais, sempre levando em consideração a divergência genética e a capacidade de combinação destes materiais. Os modelos propostos para análise dialélica assumem restrições como: segregação diplóide, ausência de alelismo múltiplo, genes distribuídos independentemente nos parentais e ausência de epistase.

O desenvolvimento da teoria dessa análise teve início após os trabalhos de Sprague \& Tatum (1942), que introduziram os conceitos de capacidade geral e específica de combinação. A capacidade geral é entendida como o comportamento médio de uma linhagem, cultivar ou outro material genético, em um conjunto de cruzamentos; e a capacidade específica de 
combinação é o desvio de uma combinação híbrida em particular em relação ao comportamento médio esperado de seus respectivos parentais.

Como métodos mais importantes para análise dialélica podem ser citados Jinks \& Hayman (1953), Griffing (1956) e Gardner \& Eberhart (1966). Eles permitem estimar os efeitos aditivos e de dominância, componentes da variância genética e outros parâmetros como herdabilidade e grau médio de dominância. Estes métodos foram discutidos, revistos e/ou ampliados por diferentes autores entre eles: Haymam (1954 a, b) Jones (1965), Nassar (1965), Kearsey (1965), Murty \& Anand (1966), Arunachalam (1976), Baker (1978), Kenworthy (1980), Miranda Filho \& Geraldi (1984), Ferreira (1985), Cruz \& Vencovsky (1989).

A maioria dos estudos utilizando as análises dialélicas e a capacidade de combinação, em autógamas, tem sido realizados envolvendo gerações segregantes, obtidas a partir de parentais homozigóticos, onde o nivel de endogamia é pequeno. Em espécies autógamas, devido ao fato dos genótipos selecionados representarem linhagens puras, o conhecimento da capacidade geral de combinação, que é função dos efeitos aditivos dos genes, torna-se de grande interesse. A partir da capacidade geral de combinação podem-se obter informações sobre a participação dos efeitos aditivos na amplitude de variação das gerações segregantes de um referido cruzamento. Isto permite traçar as melhores estratégias para um programa de melhoramento.

\subsection{Delineamentos aumentados e o melhoramento de plantas}

Os delineamentos aumentados foram propostos por Federer (1956) com o objetivo de atender a uma necessidade do programa de melhoramento do "Hawaiian Sugar Planter's Association". O autor buscava uma solução para o problema de testar um grande número de clones de cana-de-açúcar, nas 
fases preliminares do programa, quando se dispõe de pouco material para propagação. Estes delineamentos possibilitavam também um menor dispêndio de recursos.

Um delineamento aumentado, segundo Federer (1956), pode ser entendido como um delineamento tradicional (inteiramente ao acaso, blocos casualizados, reticulados, quadrado latino, etc) que recebe tratamentos adicionais. Pode ser estruturado por exemplo, a partir do aumento de unidades experimentais dos blocos, que podem ser completos ou incompletos, e alocando-se novos tratamentos a estas parcelas.

Estes delineamentos apresentam dois conjuntos de tratamentos, sendo o primeiro denominado de testemunhas ou tratamentos comuns, que são repetidos j vezes em todos os blocos, e, o segundo denominado de adicionais ou regulares, que aparecem uma única vez no experimento.

Dentre os delineamentos aumentados apresentados por Federer (1956), o de blocos foi considerado o mais promissor para os testes clonais em cana-de-açúcar.

Convém salientar que a expressão delineamento experimental aumentado só foi apresentada por Federer (1961). Segundo o autor, a análise destes delineamentos é feita, inicialmente, conforme o delineamento padrão para os tratamentos comuns, excetuando-se os tratamentos adicionais. Posteriormente, uma outra análise é feita considerando os tratamentos comuns (testemunhas) e os regulares (adicionais), de acordo com o delineamento aumentado. Assim, o quadrado médio para o resíduo, num delineamento aumentado, é obtido analisando-se somente os dados referentes aos tratamentos comuns. Torna-se necessário, então, que se faça um ajuste dos totais e médias dos tratamentos regulares, em função do delineamento básico utilizado. Portanto, as estimativas dos efeitos dos tratamentos são ajustadas para blocos à semelhança do que se faz para blocos incompletos. As 
expressões dos estimadores e a análise de variância são baseados na análise intrablocos.

Uma característica inerente do delineamento em blocos aumentados é que o número de tratamentos regulares ou adicionais pode variar dentro dos blocos. Isto significa que não há restrições quanto ao tamanho dos blocos, que pode variar ao longo do experimento. Segundo Bearzoti (1994), tal propriedade confere uma grande flexibilidade ao modelo, pois a análise de variância não é prejudicada pela perda de tratamentos regulares. Verifica-se, também, que 0 número destes tratamentos não precisa ser fixo como nos delineamentos em blocos incompletos balanceados ou parcialmente balanceados. Estas vantagens são conseguidas às custas de uma menor precisão das estimativas dos componentes de variância, uma vez que parte das diferenças entre tratamentos está na soma de quadrados de blocos, por se tratar de uma análise intrablocos.

Duarte (1997), ao revisar o uso de delineamentos em blocos aumentados em programas de melhoramento, no período de 1975 a 1996, constatou que a maioria dos trabalhos (52\%), foi publicada após 1991 , o que significa que após sua proposição, esse tipo de delineamento permaneceu por cerca de três décadas num certo esquecimento. Duarte (1997) relata ainda, que uma característica marcante das pesquisas recentes com delineamentos aumentados é a adoção de métodos de ajustamento das observações usando informações de parcelas vizinhas.

No Brasil, este delineamento tem sido utilizado em programas de melhoramento nas culturas de soja (Farias Neto, 1995; Gomes, 1995; LaínezMejía, 1996 e Azevedo Filho, 1997) e batata (Bearzoti, 1994 e Momenté, 1994). Além disto, aspectos metodológicos têm sido relatados nos trabalhos de Nogueira (1976), Vizoni (1984), Oliveira (1986, 1988 e 1990), Barbosa (1996), Silva (1987), Carvalho (1991), Valério Filho (1991) e Marcos (1994). 
As estimativas para comparação dos tratamentos delineados em blocos aumentados baseiam-se na informação intrabloco, que é obtida através de comparação entre os valores em parcelas de um mesmo bloco. Percebe-se, então, que a aplicação de testes de médias não ajustadas não é correta, devido à presença de diferenças entre blocos.

O delineamento em blocos aumentados torna-se muito útil nas etapas iniciais de um programa de melhoramento por permitir a avaliação de um grande número de genótipos, utilizando menor área e recursos, o que the confere maior facilidade na condução e, sem ter a análise afetada pela perda de tratamentos regulares. Convém salientar que sua menor precisão na estimação de parâmetros genéticos não compromete sua utilização; entretanto, esta precisão pode ser melhorada com a recuperação da informação interblocos, à semelhança dos delineamentos em blocos incompletos.

As estimativas de componentes de variância, além do método ANOVA, mais comumente empregado, também podem ser feitas por outras metodologias como máxima verossimilhança e máxima verossimilhança restrita, além dos estimadores quadráticos não viesados (Valério-Filho, 1991).

Uma comparação com o método ANOVA e o da máxima verossimilhança restrita é feita por Scott \& Milliken (1993), a partir do delineamento em blocos completos aumentados e o programa computacional SAS. Os autores relatam que o método da máxima verossimilhança não fornece variâncias negativas, contribuindo para estimativas mais precisas. 


\section{MATERIAL E MÉTODOS}

\subsection{Material Experimental}

O material utilizado neste estudo envolveu diferentes populações obtidas a partir de cruzamentos dialélicos parciais entre genótipos resistentes e suscetíveis a insetos. Para isto, oito parentais foram selecionados com base na reação a insetos e produtividade. Como parentais resistentes foram escolhidos os genótipos Crockett, Lamar, IAC-100 e a linhagem experimental D72-9601-1. Como parentais produtivos e adaptados, mas suscetíveis, foram selecionados os cultivares BR-6 (Nova Bragg), IAS-5, Davis e OCEPAR-4 (Iguaçu). As genealogias destes materiais e a reação a insetos estão no Apêndice 1; e suas características botânicas e agronômicas no Apêndice 2 .

A geração $F_{2}$ dos 16 cruzamentos biparentais resultantes foi avaliada em 1991/92, em três experimentos, que originaram três tipos de populações. Em cada cruzamento e local, avaliaram-se 72 plantas. Estas deram origem às progênies $F_{3}$ derivadas de plantas $F_{2}\left(F_{3: 2}\right)$ que foram selecionadas ao longo das gerações de endogamia, conforme os critérios a seguir: 
a) produtividade de grãos: semeadura em 28/11/91 na área experimental do Departamento de Genética da ESALQ/USP, em Piracicaba-SP, que se situa a $22^{\circ} 42^{\prime}$ de latitude sul, $47^{\circ} 38^{\prime}$ de longitude oeste e a uma altitude de $537 \mathrm{~m}$ acima do nível do mar. Este experimento, após a seleção, com o controle de insetos, originou as populações $\mathrm{PCl}$;

b) reação a insetos sugadores: semeadura em 29/11/91 na Estação Experimental do IAC, em Mococa-SP, que se situa a $21^{\circ} 28^{\prime}$ de latitude sul, $47^{\circ} 01$ ' de longitude oeste e a uma altitude de $665 \mathrm{~m}$ acima do nivel do mar. Este experimento, sem o controle de insetos, após a seleção, originou as populações PRIS;

c) reação a insetos mastigadores: semeadura em 20/03/92 no Centro Experimental do IAC, em Campinas-SP, que se situa a $22^{\circ} 54^{\prime}$ de latitude sul, $47^{\circ} 05^{\prime}$ de longitude oeste a uma altitude de $674 \mathrm{~m}$ acima do nível do mar. Este experimento, sem o controle de insetos até o florescimento para permitir $o$ ataque de insetos mastigadores, e após este com um controle rigoroso, após a seleção, originou as populações PRIM.

Os detalhes sobre a síntese das populações e a avaliação da geração $F_{2}$ são descritos por Pinheiro (1993). Um resumo das gerações de endogamia para os três tipos de populações pode ser visto no Apêndice 3.

\subsection{Ambiente de condução dos experimentos}

Os experimentos foram conduzidos em dois locais, situados no município de Piracicaba, ou seja, na Estação Experimental de Anhembi e no campo experimental do Departamento de Genética, localizado na sede-ESALQ, a partir de agora denominado de ESALQ, pertencentes à Escola Superior de Agricultura "Luiz de Queiroz" da Universidade de São Paulo 
A E.E. Anhembi fica a $60 \mathrm{Km}$ da sede-ESALQ e apresenta um solo pertencente à classe aluvial distrófico, textura média arenosa e relevo plano. 0 solo da ESALQ é do tipo terra roxa estruturada eutrófica.

\subsection{Condução experimental}

\subsubsection{Populações PCI}

\subsubsection{Geração $F_{3}$}

A geração $F_{3}$ foi constituída de 1120 progênies $F_{3: 2}$ avaliadas em um experimento delineado em blocos aumentados de Federer (1956) com 70 blocos, a partir daqui denominados de conjuntos. Cada progênie $F_{3: 2}$ foi testada sem repetição numa fileira de $1,5 \times 0,5 \mathrm{~m}$. Em cada conjunto foram colocadas duas testemunhas (IAS-5 e IAC-100) e 16 progênies. Este experimento foi instalado na ESALQ, com semeadura em 26/05/93.

Efetuou-se a adubação no sulco, com $25 \mathrm{~g} / \mathrm{m}$ (500 kg/ha) da fórmula 420-20. A inoculação das sementes foi feita com Bradyrhizobium japonicum, sendo o inoculante diluído em água $(800 \mathrm{~g} / 20 \mathrm{I})$ e aplicado com pulverizador costal no sulco, minutos antes da semeadura. Realizou-se ainda o tratamento das sementes com Thiabendazol utilizando-se $100 \mathrm{~g} / 100 \mathrm{~kg}$ de sementes. Outros cuidados foram tomados na condução do experimento como irrigações suplementares para garantir uma boa germinação, controle de plantas invasoras e doenças. Neste experimento o controle de pragas foi realizado.

Os procedimentos experimentais foram similares para todos os experimentos, com exceção do controle de pragas, sendo. Convém ressaltar, que em alguns deles este controle não foi feito, pois objetivou-se a seleção de materiais resistentes. Quando o controle de insetos foi realizado utilizou-se um 
produto a base de Endossulfam (1,3//ha). Sendo assim, na descrição dos próximos experimentos procedimentos gerais serão suprimidos.

Nesta geração, realizou-se uma seleção fenotípica dos materiais ao nivel de campo, portanto, sem a tomada de dados em todas as progênies.

\subsubsection{Geração $F_{4}$}

As 650 progênies $F_{4: 2}$ foram avaliadas em um experimento instalado na E.E. Anhembi com semeadura em 08/06/94. Utilizou-se o delineamento de blocos aumentados, sendo as progênies testadas em fileiras de $5,0 \times 0,5 \mathrm{~m}$. Adotaram-se 25 conjuntos com 26 progênies e quatro testemunhas (IAS-5, OCEPAR-4, Crockett e IAC-100). Nesta geração, também foi realizado o controle de insetos.

\subsubsection{Geração $F_{5}$}

As progênies $F_{5: 2}$ não puderam ser avaliadas, pois devido ao excesso de pluviosidade logo após a semeadura, o experimento instalado em 18/10/95 na E.E. Anhembi foi perdido. Tornou-se necessária, então, a recuperação do material. Este procedimento foi feito de novembro/95 a junho/96 com germinação das sementes remanescentes em papel toalha, dentro de germinadores, com temperatura de $25^{\circ} \mathrm{C}$ e $100 \%$ de umidade relativa.

As plântulas obtidas foram transplantadas para copos plásticos de $300 \mathrm{ml}$ contendo uma mistura de terra, adubo orgânico e mineral, sendo cultivadas em telado por um período de 15 dias. Após este período, as plântulas $F_{5}$ foram levadas para o campo experimental da ESALQ e cultivadas em covas espaçadas $1,0 \times 0,5 \mathrm{~m}$. 
Com objetivo de maximizar a produção de sementes realizou-se também o controle de pragas.

\subsubsection{Geração $F_{6}$}

O experimento para avaliar as progênies $F_{6: 2}$ foi instalado na $E . E$. Anhembi em 09/07/96. Adotou-se o delineamento de blocos aumentados com a parcela experimental representada por duas fileiras de $5,0 \times 0,5 \mathrm{~m}$. As 625 progênies $F_{6: 2}$ Foram distribuídas em 25 conjuntos, sendo cada um deles composto de 25 progênies e quatro testemunhas (IAS-5, Davis, OCEPAR-4 e IAC-100). Também aqui houve controle de insetos.

\subsubsection{Geração $F_{7}$}

Para avaliar as 100 progênies $F_{7: 2}$ selecionadas, foram instalados dois experimentos em blocos ao acaso com repetições estratificadas em conjuntos experimentais com testemunhas comuns. Foram empregadas duas repetições dos conjuntos por local. O primeiro experimento foi semeado em 28/04/97 na E.E. Anhembi e teve quatro conjuntos de 25 progênies e quatro testemunhas. Os materiais utilizados como testemunha foram: IAS-5, Davis, OCEPAR-4 e IAC-100. A parcela experimental foi representada por três fileiras de 5,0 x 0,5m. A semeadura do segundo experimento foi realizada na ESALQ, também com quatro conjuntos de 25 progênies e quatro testemunhas (as mesmas do experimento anterior).

Nestes experimentos não houve o controle de insetos, pois objetivou-se avaliar o comportamento destas progênies quanto à reação a insetos. 


\subsubsection{Populações PRIS}

\subsubsection{Geração $F_{3}$}

A geração $F_{2}$ das populações $P R I S$ foram avaliadas para insetos sugadores na E.E. Mococa do IAC. O intenso ataque de percevejos nas plantas $F_{2}$ prejudicou a germinação das sementes $F_{3}$, sendo necessária a recuperação do material, a qual foi realizada em papel toalha dentro de germinadores com $25^{\circ} \mathrm{C}$ e $100 \%$ de umidade relativa. Este procedimento foi similar ao descrito no item 3.3.1.3., sendo feito de agosto/93 a maio/94.

\subsubsection{Geração $F_{4}$}

As 350 progênies $F_{4: 3}$ foram semeadas em 08/06/94 na E.E. Anhembi no delineamento em blocos aumentados. Cada progênie foi avaliada em uma fileira de $1,0 \times 0,5 \mathrm{~m}$. Este experimento foi composto por 14 conjuntos de 25 progênies e quatro testemunhas, sendo estas IAS-5, OCEPAR-4, Crockett e IAC-100.

O controle de insetos foi feito com objetivo de maximizar a produção de sementes.

\subsubsection{Geração $F_{5}$}

O experimento com as progênies $F_{5: 3}$, instalado na E.E. Anhembi em 18/10/95, foi perdido devido ao excesso de pluviosidade, logo após a semeadura. Os procedimentos para recuperação do material foram feitos de novembro/95 a junho/96 e encontram-se descritos no item 3.3.1.3. 


\subsubsection{Geração $F_{6}$}

O experimento, em blocos aumentados, para avaliar as 575 progênies $F_{6: 3}$ foi semeado em 09/07/97 na E.E. Anhembi. A parcela experimental utilizada foi de duas fileiras de $5,0 \times 0,5 \mathrm{~m}$, sendo o material distribuído em 23 conjuntos com 25 progênies e quatro testemunhas. Os parentais IAS-5, Davis, OCEPAR-4 e IAC-100 foram utilizados como testemunhas.

Para garantir uma boa qualidade das sementes realizou-se o controle químico de insetos.

\subsubsection{Geração $F_{7}$}

$\mathrm{Na}$ geração $F_{7}$ foram instalados dois experimentos em blocos ao acaso com repetições estratificadas em conjuntos experimentais com testemunhas comuns. Foram empregadas duas repetições dos conjuntos por local. Na E.E. Anhembi, com semeadura em 28/04/97, as 125 progênies $F_{7: 3}$ foram avaliadas em cinco conjuntos, cada conjunto com 25 progênies e quatro testemunhas (IAS-5, Davis, OCEPAR-4 e IAC-100). A parcela experimental foi de três fileiras de 5,0 x 0,5m. O segundo experimento foi semeado em 14/05/97, na ESALQ, e seguiu as mesmas características do experimento anterior.

Com o objetivo de se avaliar a reação das progênies a insetos não foi realizada nenhuma medida de controle químico. 


\subsubsection{Populações PRIM}

\subsubsection{Geração $F_{3}$}

A avaliação das 1104 progênies $F_{3: 2}$ foi realizada na ESALQ, com semeadura em 17/11/93, também em um delineamento de blocos aumentados. A parcela experimental foi representada por uma fileira de $1,0 \times 0,5 \mathrm{~m}$. Foram delineados 69 conjuntos, cada um com 16 progênies e quatro testemunhas (IAS-5, OCEPAR-4, Crockett e IAC-100). Nesta geração, houve controle de insetos e a seleção foi realizada em condições de campo, com base no fenótipo, sem a coleta de dados.

\subsubsection{Geração $F_{4}$}

Para avaliar as 800 progênies $F_{4: 2}$, foi instalado um experimento na E.E.Anhembi, com semeadura em 02/02/95, seguindo o delineamento de blocos aumentados. A parcela experimental foi de uma fileira de $2,0 \times 0,5 \mathrm{~m}$. Utilizaram-se 32 conjuntos com 25 progênies e quatro testemunhas, sendo estas IAS-5, OCEPAR-4, Crockett e IAC-100.

O controle de insetos foi realizado para garantir maior produção de sementes.

\subsubsection{Geração $F_{5}$}

A geração $F_{5}$ foi avaliada em um experimento na E.E. Anhembi, com semeadura em 18/10/95. Apesar da intensa pluviosidade após a semeadura, este experimento pôde ser aproveitado. As 350 progênies $F_{5: 2}$ foram 
distribuídas em 14 conjuntos com 25 progênies e quatro testemunhas (IAS-5, OCEPAR-4, Crockett e IAC-100), também em blocos aumentados.

Cada progênie foi avaliada em uma parcela de uma fileira de $2,0 \times 0,5 \mathrm{~m}$, sendo feito o controle de insetos.

\subsubsection{Geração $F_{6}$}

As 175 progênies $F_{6: 2}$ foram semeadas em 09/07/96 na E.E. Anhembi. Adotou-se o delineamento em blocos aumentados com sete conjuntos de 25 progênies e quatro testemunhas (IAS-5, Davis, OCEPAR-4 e IAC-100). A parcela experimental foi representada por duas fileiras de $5,0 \times 0,5 \mathrm{~m}$. Nesta geração também realizou-se o controle de insetos.

\subsubsection{Geração $F_{7}$}

O delineamento em blocos ao acaso com repetiçōes estratificadas em conjuntos experimentais com testemunhas comuns foi utilizado para avaliar as 75 progênies $F_{7: 2}$ em dois experimentos, com duas repetiçōes de cada conjunto por local. Um destes experimentos foi semeado em 28/04/97 na E.E. Anhembi, sendo o outro instalado na ESALQ com semeadura em 30/04/97. Foram adotados três conjuntos por experimento com 25 progênies e quatro testemunhas (IAS-5, Davis, OCEPAR-4 e IAC-100). Cada parcela experimental foi constituída de três fileiras de 5,0 × 0,5m.

Como objetivou-se avaliar a reação das progênies $F_{7: 2}$ a insetos, nenhuma medida de controle foi adotada. 


\subsection{Caracteres avaliados}

Para cada experimento, nas diferentes gerações e para os três tipos de populações, os seguintes caracteres foram avaliados:

NDM: número de dias para a maturidade, contados desde a semeadura até a data em que $95 \%$ das vagens apresentaram-se maduras;

APM: altura da planta $(\mathrm{cm})$ na maturidade, medida desde a base da planta (no solo) até o ápice da haste principal;

VA: valor agronômico, avaliado na maturidade através de uma escala de notas visuais de 1 a 5 , sendo a nota 1 correspondente a uma planta sem nenhum valor agronômico e a nota 5 a uma planta com excelentes características agronômicas (ausência de hastes verdes, sem retenção foliar, grande número de vagens, altura superior a $60 \mathrm{~cm}$, inserção da primeira vagem acima de $12 \mathrm{~cm}$, sem acamamento, sem debulha de vagens e sem sintomas de doenças). O caráter VA foi avaliado através de notas visuais, e por esta razão tais dados foram transformados para aproximação à distribuição normal. Utilizou-se a transformação $\sqrt{x}+0,5$. Deve-se salientar ainda que este caráter foi utilizado na avaliação direta da resistência de soja a percevejos. Tal procedimento baseou-se nos resultados obtidos por Pinheiro (1993).

PG: produtividade de grãos (g/parcela), avaliada na maturidade através do peso dos grãos das parcelas, após a padronização da umidade. Este caráter foi transformado posteriormente para kg/ha. 


\subsection{Análises estatístico-genéticas}

\subsubsection{Análises individuais de variância}

Os dados obtidos em todos os experimentos foram submetidos à análise de variância, em blocos aumentados de acordo com o modelo matemático a seguir:

Sendo,

$$
Y_{i i^{\prime} j}=\mu+t_{i}+t_{i ' j}+b_{j}+e_{i j}
$$

$Y_{i i j}$ : valor observado na parcela do bloco j que recebeu o tratamento comum $i$ ou o tratamento regular i';

$\mu$ : efeito fixo da média geral;

$t_{i}$ : efeito fixo do tratamento comum $i ; i=1,2, \ldots, T$;

$t_{i j}$ : efeito do tratamento regular i' do bloco j, tido como aleatório;

$\mathrm{i}^{\prime}=1,2, \ldots, \mathrm{n}_{\mathrm{j}}-\mathrm{T}$; onde $\mathrm{n}_{\mathrm{j}}=$ número de parcelas do bloco $\mathrm{j}$;

$b_{j}$ : efeito aleatório do bloco j; $j=1,2, \ldots, B$;

$e_{i j}$ : efeito aleatório do erro experimental associado à parcela do bloco j que recebeu o tratamento comum i ou o tratamento regular i'; admite-se que o erro tem distribuição normal e é independentemente distribuído com média zero e variância $\sigma^{2}$.

$\mathrm{Na}$ Tabela 1 encontra-se o esquema da análise de variância do modelo citado, onde o resíduo intrablocos $\left(\sigma^{2}\right)$, obtido na referida análise, permite comparações entre tratamentos regulares.

Para as gerações $F_{7}$ dos três tipos de populações foi realizada uma análise de variância considerando-se apenas as testemunhas comuns e mantendo-se o delineamento de conjuntos experimentais. Nesse tipo de análise as significâncias dos efeitos de conjuntos $e$ da interação testemunhas $x$ 
conjuntos indicariam a necessidade de se realizar o ajuste dos valores das progênies para neutralizar o efeito de conjuntos experimentais. A significância destes efeitos implicará na manutenção da estratificação de conjuntos. Caso contrário, a análise de variância poderá ser feita de acordo com o modelo de blocos ao acaso.

\subsubsection{Análises de variância envolvendo diferentes ambientes}

Após a análise de variância seguindo o delineamento em blocos aumentados, para cada experimento, obtiveram-se as médias ajustadas para os tratamentos regulares (progênies) e para os tratamentos comuns (testemunhas). Uma nova análise de variância foi realizada, com as médias ajustadas, de acordo com o modelo apresentado no item 3.5.1., onde se considerou cada experimento, de cada geração e dentro dos diferentes tipos de populações, como se fossem blocos. Com isso, obteve-se um novo ajuste envolvendo todos os ambientes, aqui representados por locais e épocas. Desta forma, foi possivel uma comparação entre os tratamentos de todos os experimentos dentro e entre as populações.

\subsubsection{Ganho Genético}

Avaliou-se o ganho genético a partir das médias ajustadas gerais das progênies, em função das gerações, através do método de regressão linear. As variáveis independentes (eixo $\mathrm{X}$ ) corresponderam às gerações de endogamia $\mathrm{e}$ as dependentes (eixo $\mathrm{Y}$ ), aos caracteres avaliados. A regressão linear associa as variáveis dependentes e independentes de acordo com a seguinte expressão (Steel \& Torrie, 1980): 


$$
Y=a+b X_{k}+e
$$

onde,

Y : variável dependente;

a : coeficiente linear da reta;

b : coeficiente angular da reta;

$X_{k}$ : k-ésima variável independente (no caso, $k$ varia de 1 a 4 , ou seja, da geração $F_{4}$ a geração $F_{7}$ );

e : erro experimental associado.

As equações foram estimadas para as variáveis NDM, APM, VA e PG, para os três tipos de populações, nas diferentes gerações de endogamia. $O$ parâmetro "a" estima o valor da variável analisada, na geração 0 (se os dados puderem ser ajustados a uma reta). O valor "b", que em termos matemáticos é a tangente do ângulo da reta, estima a alteração na variável dependente por geração. Valores de "b" significativos, quando positivos, indicam um aumento ao longo das gerações e quando negativos, indicam redução. Valores não significativos traduzem-se na impossibilidade de traçar a reta. Expressou-se, então, o valor de "b" em porcentagem do valor de "a", ou seja a alteração porcentual por geração (b\%).

Estimou-se ainda o coeficiente de determinação $\left(r^{2}\right)$, que mede o ajuste dos dados à reta de regressão.

\subsubsection{Capacidade média de combinação $\left(\mathrm{cmc}_{\mathbf{i}}\right)$}

A capacidade média de combinação de cada parental $\left(\mathrm{cmc}_{\mathrm{i}}\right)$, em combinações híbridas, em cada experimento, foi estimada pelo desempenho de suas linhagens conforme a expressão a seguir: 


$$
\mathrm{cmc}_{\mathrm{i}}=\mathrm{C}_{\mathrm{i}}-\mathrm{C}_{\text {. }}
$$

sendo:

$\Sigma \mathrm{Cmc}_{\mathrm{i}}=0$

onde,

$\mathrm{cmc}_{\mathrm{i}}$ : capacidade média de combinação do parental $\mathrm{i}$;

$\mathrm{C}_{\mathrm{i} .}$ : média dos cruzamentos em que o parental i participou;

C.. : média geral dos cruzamentos.

\subsubsection{Correlação entre caracteres}

A partir das médias ajustadas das progênies, para todas as gerações, calculou-se o coeficiente de correlação fenotípica de Pearson entre os caracteres avaliados. Para o cálculo da significância das correlações fenotípicas aplicou-se o teste $t$, com $t=r / s_{r}$, onde $r$ é o coeficiente de correlação e $s_{r}$ representa o erro padrão do coeficiente de correlação, testado com (n-2) graus de liberdade, para $n=k$ tratamentos (Steel \& Torrie,1980).

$$
S_{\mathrm{r}}=\sqrt{\frac{\left(1-r^{2}\right)}{(n-2)}}
$$




\subsubsection{Associação entre gerações}

Os coeficientes de correlação de Spearman $\left(r_{s}\right)$ foram estimados entre os ambientes, com base no desempenho médio das progênies dentro de cada cruzamento, para os caracteres avaliados, de acordo com a expressão apresentada por Steel \& Torrie (1980):

$$
r_{s}=1-\frac{6 \sum_{i} d i^{2}}{(n-1) n(n+1)}
$$

Sendo,

di : diferença entre o i-ésimo par;

$\mathrm{n}$ : número de pares;

Através das estimativas de correlação procurou-se observar o efeito de escala ambiental na ordem classificatória ("rank") dos valores individuais das diferentes gerações, já que estas foram conduzidas em ambientes diferentes (anos, locais, épocas). 


\section{RESULTADOS E DISCUSSÃO}

\subsection{Análise das progênies}

Nas tabelas 2 a 13 constam os resultados referentes aos experimentos conduzidos em Anhembi e ESALQ com comportamento das progênies (média ajustada e variância) nos diferentes tipos de populações e gerações de endogamia. Os caracteres avaliados foram reunidos e discutidos por população.

\subsubsection{Populações $\mathrm{PCl}$}

As populações $\mathrm{PCl}$ foram obtidas a partir de um experimento, conduzido na cidade de Piracicaba-SP, onde se avaliou a geração $F_{2}$ para o caráter principal de produtividade de grãos.

Com base nos caracteres avaliados nas populações $\mathrm{PCl}$ verifica-se, (tabelas 2 a 5), que dentre os 16 cruzamentos (identificados no apêndice 4), o 
cruzamento (4) BR-6 $\times$ D72-9601-1, na geração $F_{7}$, foi o único que não apresentou nenhuma progênie selecionada.

Para o caráter número de dias para a maturidade, as médias gerais das progênies foram 144,124 e 129 dias para as gerações $F_{4}, F_{6}$ e $F_{7}$ respectivamente, sendo que as médias das testemunhas nestas gerações foram 144, 123 e 127 dias. As médias das testemunhas e das progênies foram semelhantes nas gerações avaliadas.

$\mathrm{Na}$ geração $\mathrm{F}_{4}$, seis cruzamentos foram mais tardios em relação à média geral das progênies (144 dias):

- (7) IAS-5 x IAC-100 (156 dias)

- (11) Davis x IAC-100 (155 dias)

- (15) OCEPAR-4 x IAC-100 (152 dias)

- (9) Davis $\times$ Crockett (148 dias)

- (4) BR-6 x D72-9601-1 (148 dias)

- (5) IAS-5 x Crockett (146 dias)

Ao se observar a tabela 2 verifica-se que na geração $F_{6}$ quatro cruzamentos são mais tardios que a média geral das progênies (124 dias).

- (11) Davis x IAC-100 (127 dias)

- (15) OCEPAR-4 x IAC-100 (127 dias)

- (7) IAS-5 x IAC-100 (125 dias)

- (1) BR-6 x Crockett (125 dias)

A geração $F_{7}$ foi avaliada em Anhembi e na ESALQ, contudo a média das progênies e das testemunhas foram semelhantes nos dois locais. Entre os cruzamentos mais tardios em relação à média das progênies (129 dias) estiveram:

- (5) IAS-5 x Crockett (131 dias)

- (7) IAS-5 x IAC-100 (130 dias)

- (11) Davis x IAC-100 (130 dias)

- (16) OCEPAR-4 x IAC-100 (130 dias)

- (16) OCEPAR-4 x D72-9601-1 (130 dias) 
- (1) BR-6 x Crockett (130 dias)

Pode-se destacar como mais precoces os cruzamentos envolvendo o cultivar Lamar, confirmando o que foi verificado por Pinheiro (1993) na geração $F_{2}$.

Para o cultivo fora de época tem-se a necessidade de se identificarem genótipos menos sensiveis ao fotoperíodo, ou seja, materiais que mesmo sendo cultivados fora da época recomendada apresentem uma indução floral tardia. Observa-se que, com a seleção ao longo das gerações, a variância fenotípica entre as progênies diminuiu para este caráter, bem como o número de genótipos superiores às testemunhas. A variância fenotípica entre as progênies dentro dos cruzamentos oscilou de 44,80 dias ${ }^{2}$ ((6) IAS-5 $\times$ Lamar) a 198,22 dias $^{2}$ ((4) BR-6 x D72-9601-1), na geração $F_{4}$. Essa oscilação foi menor na geração $F_{6}$ variando de 1,42 dias ${ }^{2}$ para (6) IAS-5 $x$ Lamar a 26,28 dias ${ }^{2}$ para o cruzamento (2) BR-6 $\times$ Lamar.

A geração $F_{7}$ foi conduzida em dois locais, sendo que a variância fenotípica encontrada para APM entre as progênies foi superior em Anhembi em relação a ESALQ.

A avaliação da altura da planta na maturidade é apresentada na tabela 3. Em todas as gerações verificou-se a presença de cruzamentos com progênies apresentando altura superior à média geral das progênies e à média das testemunhas.

$\mathrm{Na}$ geração $\mathrm{F}_{4}$, cinco cruzamentos foram superiores para APM quando comparados com a média das progênies $(41 \mathrm{~cm})$, sendo eles:

- (7) IAS-5 x IAC-100 (51 cm)

- (15) OCEPAR-4 x IAC-100 (50 cm)

- (11) Davis $\times$ IAC-100 (45 cm)

- (4) BR-6 X D72-9601-1 (45 cm)

- (3) BR-6 x IAC-100 (45 cm)

Verifica-se na geração $F_{6}$, onde a média das progênies foi de $56 \mathrm{~cm}$, que além desses cruzamentos merece destaque (1) BR-6 x Crockett $(65 \mathrm{~cm})$. 
$\mathrm{Na}$ geração $\mathrm{F}_{7}$ houve uma pequena diferença entre as médias das progênies nos dois locais, Anhembi e ESALQ, $51 \mathrm{~cm}$ e $56 \mathrm{~cm}$, respectivamente. Os seguintes cruzamentos destacaram-se nos dois locais:

- (7) IAS-5 x IAC-100 (54 e $57 \mathrm{~cm})$

- (11) Davis x IAC-100 (54 e $57 \mathrm{~cm})$

- (15) OCEPAR-4 x IAC-100 (55 e $62 \mathrm{~cm})$

- (3) BR-6 x IAC-100 (52 e $57 \mathrm{~cm})$

Em relação à variância na geração $F_{4}$ observa-se uma oscilação entre $49,71 \mathrm{~cm}^{2}$ ((6) IAS-5 x Lamar) e $334,17 \mathrm{~cm}^{2}$ ((4) BR-6 x D72-9601-1). Essa oscilação foi menor na geração $F_{6}$, variando de $13,19 \mathrm{~cm}^{2}((6)$ IAS-5 x Lamar) a $160,50 \mathrm{~cm}^{2}$ ((2) BR-6 x Lamar).

Ao se analisar a geração $F_{7}$, em relação aos dois locais de cultivo, constata-se que na ESALQ, além das progênies apresentarem média superior, a variância fenotípica também foi maior.

Para o caráter valor agronômico (tabela 4), que pode avaliar diretamente a resistência a insetos, além de caracteres agronômicos, verifica-se que nas gerações $F_{4}$ e $F_{6}$, onde houve controle de insetos, os cruzamentos que se destacaram foram aqueles que envolveram o cultivar IAC-100. Além desses cruzamentos pode-se destacar ainda (1) BR-6 x Crockett.

Verifica-se, na tabela 5, que para o caráter produtividade de grãos, na geração $F_{4}$, a média das progênies foi de $785,15 \mathrm{~kg} / \mathrm{ha}$ e a média das testemunhas de $712,26 \mathrm{~kg} / \mathrm{ha}$. Este comportamento não se manteve na geração $F_{6}$, pois neste caso a média das testemunhas foi superior a das progênies. $\mathrm{Na}$ geração $F_{7}$, o local ESALQ apresentou maior produtividade, tanto para a média das progênies quanto para a média das testemunhas.

Destacaram-se na geração $\mathrm{F}_{4}$ os seguintes cruzamentos:

- (7) IAS-5 x IAC-100 (1.224 Kg/ha)

- (15) OCEPAR-4 x IAC-100 (1.154 Kg/ha)

- (3) BR-6 x IAC-100 (834 kg/ha)

- (5) IAS-5 x Crockett (810 kg/ha) 
- (13) OCEPAR-4 x Crockett $(787 \mathrm{~kg} / \mathrm{ha})$

$\mathrm{Na}$ geração $F_{6}$, além destes cruzamentos destacam-se os cruzamentos envolvendo o cultivar BR-6 (Nova Bragg).

Ao se analisar a geração $F_{7}$ nota-se que os cruzamentos superiores foram os mesmos em Anhembi e ESALQ:

- (1) BR-6 x Crockett (978 e $975 \mathrm{~kg} / \mathrm{ha}$ )

- (15) OCEPAR-4 x IAC-100 (786 e $1.003 \mathrm{~kg} / \mathrm{ha})$

- (7) IAS-5 x IAC-100 (779 e $1.140 \mathrm{~kg} / \mathrm{ha}$ )

- (11) Davis x IAC-100 (717 e 1008 kg/ha)

- (16) OCEPAR-4 x D72-9601-1 (697 e $1.025 \mathrm{~kg} / \mathrm{ha}$ )

A variância fenotípica entre as progênies, para este caráter, nos cruzamentos oscilou de $40.457(\mathrm{~kg} / \mathrm{ha})^{2}$ ((4) BR-6 x D72-9601-1) a 616.275 $(\mathrm{kg} / \mathrm{ha})^{2}$ ((16) OCEPAR-4 x D72-9601-1) na geração $F_{4}$. Na geração $F_{6}$ esta amplitude ficou entre $362(\mathrm{~kg} / \mathrm{ha})^{2}$ ((2) BR-6 x Crockett), e 832.077 (kg/ha) ${ }^{2}$ ((6) IAS-5 x Lamar).

A geração $F_{7}$ apresentou maior variância entre as progênies para o local ESALQ (118.884 (kg/ha) $)^{2}$ ), quando comparado com Anhembi (66.652 (kg/ha) $\left.{ }^{2}\right)$. Em ambos os locais (Anhembi e ESALQ, respectivamente) os cruzamentos com maior variância fenotípica foram (14) OCEPAR-4 x Lamar (135.453 e $\left.195.074(\mathrm{~kg} / \mathrm{ha})^{2}\right),(16)$ OCEPAR-4 x D72-9601-1 (86.330 e 157.764 (kg/ha) ${ }^{2}$ ) e (8) IAS-5 x D72-9601-1 (74.808 e $\left.192.021(\mathrm{~kg} / \mathrm{ha})^{2}\right)$. Nestes cruzamentos verificou-se um pequeno número de progênies.

\subsubsection{Populações PRIS}

As populações PRIS foram obtidas a partir de um experimento, conduzido na cidade de Mococa-SP, onde se avaliou a geração $F_{2}$ para 0 caráter principal de resistência a insetos sugadores. 
Nos experimentos realizados para avaliar as progênies dos diferentes cruzamentos, nas populações PRIS, também avaliou-se NDM, APM, VA e PG. Os resultados encontram-se nas tabelas 6 a 9 .

Verificou-se que alguns cruzamentos não tiveram nenhuma progênie selecionada ao longo das gerações de endogamia, sendo estes:

- (5) IAS-5 x Crockett

- (8) IAS-5 x D72-9601-1

- (13) OCEPAR-4 x Crockett

- (16) OCEPAR-4 x D72-9601-1

Para o caráter NDM, na geração $F_{4}$, a média geral das progênies (148 dias) foi superior à média das testemunhas (143 dias). Estas médias na geração $F_{6}$ foram, respectivamente, 127 e 123 dias e na geração $F_{7,} 132$ a 127 dias, para Anhembi, e 137 e 131 dias para ESALQ. À semelhança da geração $F_{4}$, a média das progênies também foi superior à média das testemunhas nas diferentes épocas de semeadura.

$\mathrm{Na}$ tabela 6 pode-se verificar que os cruzamentos mais tardios, em todas as gerações foram:

- (3) BR-6 x IAC-100 (160,128, 133 e 140 dias)

- (4) BR-6 x D72-9601-1 (159, 128, 132 e 139 dias)

- (11) Davis x IAC-100 (159, 129, 132 e 138 dias)

A variância fenotípica das progênies oscilou de 0,40 dias $^{2}((10)$ Davis $x$ Lamar) a 171,25 dias ${ }^{2}$ ((16) OCEPAR-4 x D72-9601-1), na geração $F_{4}$, e de $0,71 \operatorname{dias}^{2}$ ((10) Davis $\times$ Lamar) a 27,35 dias ${ }^{2}$ ((11) Davis x IAC-100), na geração $F_{6}$. Na geração $F_{7}$ esta amplitude foi maior na ESALQ $\left(67\right.$ dias $^{2}$ ) que em Anhembi (9 dias ${ }^{2}$ ). Em ambos os locais o cruzamento (11) Davis $\times$ IAC-100 foi o que apresentou maior amplitude, 16 e 104 dias $^{2}$, respectivamente, para Anhembi e ESALQ.

$\mathrm{Na}$ tabela 7 pode ser vista a avaliação da APM, onde se constata que em todas as gerações existem cruzamentos cujas progênies apresentam altura superior a média geral, tanto das progênies quanto das testemunhas. 
$\mathrm{Na}$ geração $\mathrm{F}_{4}$ destacam-se, com altura superior a média das progênies $(48 \mathrm{~cm})$, os seguintes cruzamentos:

- (10) Davis x Lamar (67 cm)

- (11) Davis x IAC-100 (61 cm)

- (7) IAS-5 x IAC-100 (60 cm)

- (3) BR-6 x IAC-100 (60 cm)

Estes mesmos cruzamentos foram superiores na geração $F_{6}$, quando comparados com a média das progênies $(63 \mathrm{~cm})$. Suas alturas foram respectivamente, 70, 65, 64 e $66 \mathrm{~cm}$. Nesta geração, também pode-se destacar para APM, o cruzamento (15) OCEPAR-4 x IAC-100 (64 cm).

$\mathrm{Na}$ geração $\mathrm{F}_{7}$ as médias das progênies, para APM, foram semelhantes, sendo de $53 \mathrm{~cm}$ no local Anhembi e de $51 \mathrm{~cm}$ na ESALQ. Pode-se verificar, entretanto, que nestes dois locais os cruzamentos superiores para este caráter foram:

- (7) IAS-5 x IAC-100 (58 a $57 \mathrm{~cm})$

- (4) BR-6 x D72-9601-1 ( 56 e $53 \mathrm{~cm}$ )

- (3) BR-6 x IAC-100 (56 e $52 \mathrm{~cm}$ )

- (2) BR-6 x Lamar ( 54 e $52 \mathrm{~cm}$ )

- (11) Davis x IAC-100 (53 e $52 \mathrm{~cm}$ )

Como se esperava a variância fenotípica entre as progênies na geração $F_{4}$ foi superior às demais, oscilando de $22 \mathrm{~cm}^{2}((16)$ OCEPAR-4 x D72-9601-1) a $290 \mathrm{~cm}^{2}$ ((11) Davis x IAC-100).

O cruzamento (11) Davis $\times 1 \mathrm{AC}-100$, além de apresentar as maiores médias para APM, apresentou uma razoável variância fenotípica na geração $F_{7}$. Isto torna possível, então, a seleção de indivíduos superiores para este caráter.

Um resumo da avaliação para VA pode ser visto na tabela 8 . Nas populações PRIS, ou seja, aquelas que foram selecionadas para insetos sugadores (percevejos), verifica-se notas superiores àquelas observadas para as populações $\mathrm{PCl}$ e PRIM (tabelas 4 e 12). Isto pode ser explicado uma vez 
que nestas outras populações a seleção inicial fora realizada para a produtividade de grãos e insetos mastigadores.

Nas gerações $F_{4}$ e $F_{6}$, onde não houve controle de insetos, além dos cruzamentos que envolveram o cultivar IAC-100, pode-se destacar: (6) IAS-5 x Lamar e (14) OCEPAR-4 x Lamar.

$\mathrm{Na}$ geração $F_{7}$, onde houve o controle de insetos, as notas de VA atribuídas às progênies foram menores na ESALQ que no Anhembi, com médias de 1,9 e 1,5, respectivamente. $\mathrm{E}$ à semelhança das gerações anteriores, os cruzamentos envolvendo o cultivar IAC-100, que é resistente a insetos, tiveram melhor desempenho, com destaque também para BR-6 e Lamar.

A tabela 9 resume as informações sobre o caráter produtividade de grãos. Nesta tabela pode-se verificar que em todas as gerações a média das progênies foi superior à média das testemunhas.

$\mathrm{Na}$ geração $\mathrm{F}_{4}$ a média das progênies foi de $1.562 \mathrm{~kg} / \mathrm{ha}$, sendo que na geração $F_{6}$ esta média foi de $4.042 \mathrm{~kg} / \mathrm{ha}$. $A$ geração $F_{7}$ foi avaliada nos dois locais (Anhembi e ESALQ), sem o controle de insetos, sendo as médias de 765 e $675 \mathrm{~kg} / \mathrm{ha}$, respectivamente.

Apenas os cruzamentos (7) IAS-5 x IAC-100 e (4) BR-6 x D72-9601-1 foram superiores à média das progênies em todas as gerações, com médias respectivamente de 2.533, 4.060, 908, $938 \mathrm{Kg} / \mathrm{ha}$, em Anhembi, e 1.978, 4.018, 899 e $813 \mathrm{Kg} / \mathrm{ha}$ para ESALQ. Pode-se destacar, na geração $F_{4}$, os seguintes cruzamentos:

- (10) Davis x Lamar (3.426 kg/ha)

- (11) Davis x IAC-100 (2.715 kg/ha)

- (6) IAS-5 x Lamar ( $2.627 \mathrm{~kg} / \mathrm{ha}$ )

- (9) Davis $\times$ Crockett (1.977 kg/ha)

- (15) OCEPAR-4 x IAC-100 (1.666 kg/ha)

- (14) OCEPAR-4 x Lamar (1.627 kg/ha) 
$\mathrm{Na}$ geração $\mathrm{F}_{6}$ os melhores cruzamentos, quando comparados com a média das progênies $(4.042 \mathrm{Kg} / \mathrm{ha})$, foram:

- (10) Davis x Lamar (5.185 kg/ha)

- (2) BR-6 x Lamar (5.132 kg/ha)

- (1) BR-6 x Crockett ( $4.558 \mathrm{~kg} / \mathrm{ha}$ )

- (3) BR-6 x IAC-100 (4.363 kg/ha)

- (11) Davis x IAC-100 (4.117 kg/ha)

- (7) IAS-5 X IAC-100 (4.061 kg/ha)

Como a geração $F_{7}$ foi avaliada em dois locais (Anhembi e ESALQ) podem ser destacados como superiores, para os dois locais, os seguintes cruzamentos:

- (7) IAS-5 x IAC-100 (908 e $938 \mathrm{~kg} / \mathrm{ha})$

- (4) BR-6 x D72-9601-1 (899 e 813 kg/ha)

Estes dois cruzamentos foram os únicos superiores em todas as gerações, conforme descritos anteriormente. Em Anhembi, além desses dois cruzamentos merecem destaque: (10) Davis x Lamar (1002 kg/ha), (1) BR-6 x Crockett (881 kg/ha), (11) Davis x IAC-100 (806 kg/ha) e (3) BR-6 x IAC-100 (796 kg/ha).

A maior amplitude da variância fenotípica para as progênies, na geração $F_{7}$, foi verificada para o local ESALQ $\left(88.548(\mathrm{~kg} / \mathrm{ha})^{2}\right)$, enquanto que Anhembi apresentou $\left(58.574(\mathrm{~kg} / \mathrm{ha})^{2}\right)$.

\subsubsection{Populações PRIM}

As populações PRIM foram obtidas a partir de um experimento, conduzido na cidade de Campinas-SP, onde se avaliou a geração $F_{2}$ para o caráter principal de resistência a insetos mastigadores.

As tabelas de 10 a 13 resumem os dados referentes à avaliação das progênies, nas populações PRIM, para os caracteres NDM, APM, VA e PG. 
As progênies dos cruzamentos (2) BR-6 x Lamar, (4) BR-6 x D72-9601-1, (10) Davis $\times$ Lamar e (14) OCEPAR-4 x Lamar foram descartadas, ao longo das gerações de endogamia, por não apresentarem características de interesse.

Em todas as gerações avaliadas para NDM as médias das progênies e das testemunhas foram semelhantes.

Para o cultivo fora de época é de interesse que os materiais apresentem ciclo próximo àquele alcançado com plantio na época normal. $\mathrm{Na}$ geração $\mathrm{F}_{4}$, cuja semeadura foi em 02/02/95, verifica-se que apenas o cruzamento (7) IAS-5 x IAC-100 (116 dias) foi superior à média das progênies.

$\mathrm{Na}$ geração $F_{5}$, cuja semeadura foi em 18/10/95, ou seja, na época recomendada para cultivo, constatou-se que só o cruzamento (1) BR-6 $x$ Crockett (142 dias) superou a média das progênies (140 dias). Na geração $F_{6}$, onde a média das progênies foi de 126 dias, destacaram-se: (11) Davis $\times$ IAC100 (125 dias) e (15) OCEPAR-4 x IAC-100 (124 dias).

A média das progênies na geração $F_{7}$ (130 dias) foi praticamente a mesma nos dois locais de avaliação (Anhembi e ESALQ).

Os cruzamentos (1) BR-6 x Crockett (134 e 132 dias) e (7) IAS-5 x IAC100 (133 e 131 dias) foram os mais tardios.

A variância fenotípica das progênies para NDM, na geração $F_{7}$, foi consideravelmente maior no local Anhembi (13 dias ${ }^{2}$ ). Em ambos os locais o cruzamento com maior oscilação foi (16) OCEPAR-4 x D72-9601-1.

Para o caráter APM (tabela 11) verifica-se que o cruzamento (15) OCEPAR-4 x IAC-100 se destacou em todas as gerações por apresentar progênies com altura superior à média das progênies e também à das testemunhas. Este cruzamento apresentou APM de 26, 77, 67, 51 e $61 \mathrm{~cm}$, respectivamente, para as gerações $F_{4}, F_{5}, F_{6}$ e $F_{7}$.

Além destes cruzamentos podem ser destacados também:

- (11) Davis XIAC-100 (26, 81, 66, 49 e $58 \mathrm{~cm})$

- (7) IAS-5 x IAC-100 (29, 69, 54, 53 e $59 \mathrm{~cm})$ 
A variância fenotípica das progênies na geração mais avançada de endogamia $\left(F_{7}\right)$, foi maior na ESALQ $\left(126,90 \mathrm{~cm}^{2}\right)$ que em Anhembi $(88,26$ $\mathrm{cm}^{2}$ ). Apesar da menor estimativa de variância para as progênies em Anhembi este local apresentou uma maior variação, de $17 \mathrm{~cm}^{2}$ ((16) OCEPAR-4 x D729601-1) a 501, $38 \mathrm{~cm}^{2}$ ((13) OCEPAR-4 x Crockett). Na ESALQ esta variação foi de $7 \mathrm{~cm}^{2}$ ((9) Davis $\times$ Crockett) a 297,10 cm ((16) OCEPAR-4 x D72-96011).

A tabela 12 resume as informações sobre o caráter VA nas diferentes gerações. As notas mais altas foram, em todas as gerações, verificadas para os seguintes cruzamentos:

- (7) IAS-5 x IAC-100 (1,48; 1,69; 1;84; 1,85 e 1,59)

- (11) Davis X IAC-100 (1,45; 1,85; 1,67; 1,83 e 1,71)

- (15) OCEPAR-4 x IAC-100 (1,46; 1,83; 1,86; 1,79 e 1,64)

As informações sobre o caráter produtividade de grãos foram resumidas na tabela 13. Verifica-se que, nas gerações $F_{4}, F_{5}$ e $F_{6}$, a média das testemunhas foi superior a média das progênies. Este comportamento se alterou na geração $F_{7}$, onde as progênies produziram mais que as testemunhas. Nesta geração as médias tanto das progênies quanto das testemunhas foram maiores na ESALQ que em Anhembi.

Destacaram-se com produtividade de grãos superior à média das progênies, em todas as gerações, os seguintes cruzamentos:

- (7) IAS-5 x IAC-100 (962, 4.851, 3.013, 880 e $1.063 \mathrm{~kg} / \mathrm{ha})$

- (15) OCEPAR-4 x IAC-100 (1.234, 6.166, 3.136, 731 e $1.123 \mathrm{~kg} / \mathrm{ha})$

$\mathrm{Na}$ geração $\mathrm{F}_{4}$, além desses cruzamentos merecem destaque aqueles com médias superiores à média das testemunhas $(1.015 \mathrm{~kg} / \mathrm{ha})$, superior à média geral de todas as progênies:

- (10) Davis x Lamar (1.220 kg/ha)

- (9) Davis x Crockett (1.087 kg/ha)

$\mathrm{Na}$ geração $F_{5}$ não houve nenhum cruzamento com média de suas progênies superior à média das testemunhas $(5.412 \mathrm{~kg} / \mathrm{ha})$. Este 
comportamento também foi verificado na geração $F_{6}$, onde a média das testemunhas foi de $3.360 \mathrm{~kg} / \mathrm{ha}$.

As médias das progênies na Geração $F_{7}$ foram 628 e $917 \mathrm{~kg} / \mathrm{ha}$, respectivamente, para Anhembi e ESALQ. Nesta geração, além dos cruzamentos (7) IAS-5 x IAC-100 e (15) OCEPAR-4 x IAC-100, já mencionados como superiores em todas as gerações, destacou-se o cruzamento (1) BR-6 x Crockett (813 e $989 \mathrm{Kg} / \mathrm{ha})$.

A variância fenotípica das progênies, na geração $F_{7}$, foi maior na ESALQ $\left(139.848(\mathrm{~kg} / \mathrm{ha})^{2}\right)$ que em Anhembi $\left(66.609(\mathrm{~kg} / \mathrm{ha})^{2}\right)$. Este local também apresentou maior amplitude para esta estimativa, variando de $2.211(\mathrm{~kg} / \mathrm{ha})^{2}$ ((5) IAS-5 x Crockett) a $624.589(\mathrm{~kg} / \mathrm{ha})^{2}$ ((12) Davis x D72-9601-1). Em Anhembi os extremos desta variação corresponderam aos cruzamentos (8) IAS-5 x D72-9601-1 (16.292 (kg/ha) $\left.{ }^{2}\right)$ e (12) Davis x D72-9601-1 (288.547 $\left.(\mathrm{kg} / \mathrm{ha})^{2}\right)$.

\subsubsection{Considerações sobre a análise das progênies}

De uma forma geral, o cultivo fora da época também serviu para simular condições de baixa latitude $\left(<15^{\circ} \mathrm{LS}\right.$ ), pois afetou o desenvolvimento das progênies sensiveis ao fotoperíodo.

Após a avaliação dos diferentes tipos de populações e nas diferentes gerações de endogamia, constatou-se que é possivel a identificação de genótipos mais promissores para o cultivo fora da época recomendada. Este interesse é principalmente para o plantio subsequente ao da época normal, o que permitiria o cultivo da chamada "safrinha".

Em concordância com os resultados obtidos por Pinheiro (1993), observa-se que as progênies originadas dos cruzamentos com o cultivar IAC100 apresentaram, em geral, melhor desempenho para os caracteres avaliados. 
$\mathrm{Na}$ avaliação da geração $\mathrm{F}_{2}$ este parental apresentou a melhor capacidade de combinação.

Os cruzamentos envolvendo os parentais Davis e OCEPAR-4, também apresentaram progênies com um bom desempenho para o caráter produtividade de grãos.

A precocidade relatada para o parental Lamar foi verificada na performance das progênies originadas de cruzamentos a partir deste genótipo. Convém salientar que houve uma redução do ciclo, devido ao cultivo fora de época. Isto promoveu uma maior precocidade dos genótipos, entretanto, verifica-se a existência de genótipos mais tardios.

Entre os cruzamentos, podem ser destacados: (7) IAS-5 x IAC-100, (11) Davis $\times$ IAC-100 e (15) OCEPAR-4 x IAC-100, pois apresentaram niveis satisfatórios de produtividade nos diferentes ambientes e gerações de endogamia. As progênies destes cruzamentos, em geral, também foram superiores para os demais caracteres avaliados.

Ao se verificar os cruzamentos que compuseram a geração $F_{7}$, constatase que aqueles que envolveram o cultivar IAC-100 são representados por um maior número de progênies. Isto se verifica para os três tipos de populações.

A infestação de percevejos na geração $F_{7}$ foi alta para os dois locais (Anhembi e ESALQ), sendo predominante a espécie Piezodorus guildinii. Ficou evidente que 0 ataque de percevejos provoca alterações fisiológicas nas plantas, uma vez que a produtividade de grãos, nesta geração, foi menor. Este fenômeno é denominado retenção foliar, e interfere na produtividade de grãos. Este efeito pode ser avaliado diretamente pelo valor agronômico, que apesar de ser uma avaliação subjetiva reflete o desempenho do genótipo em relação ao ataque de percevejos e também em relação a outros caracteres agronômicos. 


\subsection{Análise de variância}

Nas tabelas de 14 a 26 constam os resumos das análises de variância (ANAVA), em blocos aumentados, com valores e significâncias dos quadrados médios dos caracteres, suas respectivas médias e coeficientes de variação. As tabelas de 14 a 17 referem-se às populações $\mathrm{PCl}$, as tabelas de 18 a 21 às populações de PRIS e as tabelas de 22 a 26 às populações PRIM.

O esquema da análise de variância em blocos aumentados encontra-se na tabela 1. Nas análises utilizou-se o erro intrablocos. A soma de quadrados da fonte de variação tratamentos foi decomposta em testemunhas, num contraste testemunhas vs progênies e progênies. Por sua vez a fonte de variação progênies foi decomposta em cruzamentos e progênies dentro de cruzamentos.

Nas populações $\mathrm{PCl}$ verifica-se efeito significativo ao nível de $1 \%$ para tratamentos ajustados, em todas as gerações e para todos os caracteres (NDM, APM, VA e PG). Após a decomposição constatou-se diferença significativa ao nível de $1 \%$ para as fontes de variação progênies e cruzamentos. Essas diferenças mostram variabilidade entre os tratamentos, progênies e cruzamentos, que possibilita a seleção de progênies com diferentes combinações de caracteres. Verifica-se ainda diferenças significativas $(P<$ $0,01)$ para progênies dentro de cruzamentos na maioria das gerações avaliadas.

As ANAVA's para as populações PRIS revelaram efeito significativo $(P<0,01)$ para os tratamentos ajustados em todos os caracteres, nas gerações de endogamia. Constatou-se também diferenças significativas, ao nível de $1 \%$, entre progênies e cruzamentos. A fonte de variação progênies dentro de cruzamentos não diferiu estatisticamente para o caráter $A P M$, na geração $F_{7}$, em Anhembi e ESALQ. Também não foi significativa a diferença para VA em Anhembi na mesma geração. 
Os tratamentos ajustados não diferiram estatisticamente para $P G$, nas populações $P R I M$ nas gerações $F_{4}$ e $F_{5}$. Este efeito também não foi significativo para APM na geração $F_{4}$ e VA na geração $F_{6}$. Logo, não houve diferença significativa entre progênies nestes casos. Verifica-se efeito significativo $(P<0,01)$ para cruzamentos em todas as gerações e para todos os caracteres. Os efeitos não significativos para tratamentos foram verificados principalmente para os caracteres APM e VA, bem como para progênies dentro de cruzamentos. Isto indica menor oportunidade de êxito no melhoramento destes caracteres.

As diferenças observadas entre tratamentos, nos diferentes tipos de populações, revelam a variabilidade existente entre as progênies para todos os caracteres avaliados. Estas diferenças são verificadas também entre cruzamentos. Logo, pode-se concluir que existem cruzamentos superiores e, dentro destes progênies com diferente desempenho. Isto possibilita a seleção de genótipos superiores entre e dentro dos cruzamentos para os caracteres avaliados.

Os coeficientes de variação experimental (CV), nos diferentes tipos de populações e gerações revelam que os caracteres NDM $(0,56 \%$ a $2,68 \%)$ e VA (3,14\% a 7,78\%) apresentaram melhor precisão experimental. Para APM, o CV atingiu valores intermediários, entre $3,68 \%$ a $21,64 \%$.

Os valores de CV obtidos para PG (3,38 a 39,69\%) são considerados aceitáveis, contudo, revelam uma menor precisão experimental para este caráter.

As magnitudes dos CV's estão de acordo com os resultados obtidos por Freire-Filho (1988), Nass (1989), Moreira (1992), Pinheiro (1993), Prado (1994), Gomes (1995) e Azevedo-Filho (1997).

Na geração $F_{4}$ das populações PRIM, o CV experimental observado para PG foi muito alto $(63,17 \%)$. Nesta geração a semeadura foi realizada em 02/02/95, fator este que pode ter contribuído para o alto valor obtido. 
De uma maneira geral, pode-se classificar a precisão experimental como satisfatória, uma vez que os valores para o CV estiveram de acordo com a literatura e os valores dos testes $F$ revelaram diferenças significativas para a quase totalidade das ANAVA's envolvendo gerações e ambientes para os diferentes caracteres.

\subsection{Ganho genético}

A partir de uma análise envolvendo todos os ambientes obteve-se as médias gerais ajustadas das progênies. Através destas estimou-se o ganho genético pelo método de regressão linear. Os parâmetros estimados por este método são mostrados na tabela 27.

Um resumo das médias ajustadas para os diferentes tipos de populações e gerações de endogamia pode ser visto na tabela 28 . Constata-se uma tendência de aumento em todos os caracteres avaliados após a seleção. Isto pode ser reforçado pela diminuição da variância fenotípica entre as progênies nas sucessivas gerações de endogamia.

$\mathrm{Na}$ análise de regressão o valor estimado para "a" (coeficiente linear da reta) indica o valor inicial do caráter avaliado na geração 0 .

As estimativas de b\% indicam o valor porcentual da alteração de "b" por geração, ou seja, o aumento por geração em relação ao valor, para o caráter, na geração inicial. Determinou-se também o coeficiente de determinação $\left(r^{2}\right)$, que revela o ajuste dos dados à reta proposta.

Verifica-se que em nenhuma das estimativas os valores de "b" foram significativos, ou seja, não diferiram estatisticamente de zero. Contudo, com exceção das populações PRIM, para o caráter produtividade de grãos (PG) estes valores foram positivos. Isto revela uma tendência de aumento no caráter selecionado ao longo das gerações. 
Os piores ajustes dos dados, em relação à reta de regressão foram verificados para o caráter PG. As populações PRIM também apresentaram um baixo coeficiente de determinação para os caracteres avaliados.

As estimativas para $b \%$, ou seja, o aumento por geração, variaram entre os tipos de populações de $0,74 \%$ a $1,41 \%$ para NDM; de $6,43 \%$ a $9,11 \%$ para APM; de $2,37 \%$ a $4,43 \%$ para VA e de $1,00 \%$ a $55,39 \%$ para $P G$.

As progênies $F_{5}$, para as populações $\mathrm{PCl}$ e 2, não puderam ser avaliadas. Isto ocorreu devido ao excesso de pluviosidade após a semeadura, realizada em 18/10/95. Para a recuperação das progênies recorreu-se a sementes remanescentes $\mathrm{F}_{4}$. Em virtude disso, houve um aumento na variabilidade entre as progênies e consequentemente uma redução na média dos caracteres avaliados. Fator este, que contribuiu para a diminuição do ganho com a seleção (tabela28).

As populações PRIM foram avaliadas nos meses de fevereiro, abril, maio, julho e outubro-novembro, respectivamente gerações $F_{3}, F_{4}, F_{5}, F_{6}$ e $F_{7}$. A seleção de genótipos superiores para cultivo fora de época pode ter sido comprometida, uma vez que houve uma ampla variação nas épocas de semeadura (10 meses). Há indícios de que os genes que controlam o florescimento tardio não são os mesmos para o cultivo antecipado e para o cultivo tardio. Isto considerando a época recomendada para o Estado de São Paulo que é o mês de novembro. Em virtude disso as equações de regressão obtidas podem ter apresentado um baixo coeficiente de determinação.

Aquele genótipo selecionado como superior, para os caracteres avaliados, onde a semeadura foi realizada em fevereiro, pode não comportar-se da mesma forma quando semeado num outro mês. Isto significa que o genótipo selecionado para cultivo em fevereiro (safrinha) pode não ser o melhor quando o cultivo for realizado, por exemplo, em setembro (semeadura antecipada), embora ambos sejam considerados como cultivo fora de época.

Tomkins \& Shipe (1997), avaliando a influência da época de cultivo em genótipos com diferentes respostas ao fotoperíodo, relatam que aqueles 
materiais com genes para florescimento tardio foram menos influenciados por esta variação.

A variação nos meses de semeadura foi menor para as populações $\mathrm{PCl}$ e 2. As gerações de endogamia para estas populações foram conduzidas no intervalo de abril a julho (4 meses).

Apesar de não ser detectado estatisticamente, as populações PRIS mostraram-se ligeiramente superiores para os caracteres avaliados. Pode-se dizer ainda que existe uma tendência de aumento na média dos caracteres avaliados ao longo das gerações, para as diferentes populações. Entretanto, os reduzidos ganhos de seleção, associados às alterações em caracteres agronômicos importantes, parecem indicar que a metodologia de ajuste empregada deve ser revista e melhor estudada.

\subsection{Capacidade média de combinação}

As estimativas de capacidade média de combinação dos parentais $\left(\mathrm{cmc}_{\mathrm{i}}\right.$ ) para NDM, APM, VA e PG, com base no desempenho de suas progênies, estão nas tabelas de 29 a 32. Constam também nestas tabelas os valores de $g_{i}$ (efeito da capacidade geral de combinação) obtidos na geração $F_{2}$ por Pinheiro (1993).

As estimativas de $\mathrm{cmc}_{\mathrm{i}}$ foram obtidas a partir do ajuste das progênies para todos os ambientes. Observa-se que, para número de dias para a maturidade (tabela 29), o parental IAC-100 foi o que apresentou valores positivos de $\mathrm{Cmc}_{\mathrm{i}}$ para a maioria da gerações, nos diferentes tipos de populações. Isto indica que este parental, em cruzamentos, contribui para um aumento no ciclo, ou seja, um retardamento na maturidade. Pinheiro (1993) estudando, a capacidade geral de combinação $\left(g_{i}\right)$, na geração $F_{2}$, encontrou estimativas positivas para NDM para este parental, em cultivo de verão (novembro) e outono-inverno (março). Esta concordância indica que a avaliação do número de dias para a maturidade, em gerações precoces, é segura. 
Para APM (tabela 30), destaca-se novamente o parental IAC-100 com estimativas positivas, o que indica sua contribuição para a aumentar a altura. 0 parental Lamar, em quase todas as gerações, apresentou valores negativos para $\mathrm{Cmc}_{\mathrm{i}}$, o que deve ser interpretado como uma redução na altura.

Nas estimativas de $\mathrm{cmc}_{\mathrm{i}}$, para valor agronômico, a maioria dos parentais apresentou pequenos valores. Entretanto, os maiores valores foram observados para o cultivar IAC-100. O cultivar Lamar apresentou valores negativos nas populações $\mathrm{PCl}$ e 3. Nas populações PRIS este cultivar apresentou estimativas muito próximas de zero.

Em capacidade média de combinação para PG, o destaque foi novamente o parental IAC-100, com valores positivos para as estimativas com exceção da geração $F_{6}$ nas populações PRIS.

Verifica-se, em concordância com Pinheiro (1993), que o parental IAC100 contribuiu para um aumento nos caracteres avaliados. Isto se deve possivelmente à presença de genes para o florescimento tardio neste cultivar.

\subsection{Correlação entre caracteres}

As estimativas dos coeficientes de correlação fenotípica de Pearson entre os caracteres NDM, APM, VA e PG encontram-se na tabela 33. Estas correlações são de importância prática para o melhorista, pois demonstram como deve ser orientada a seleção de progênies para obtenção de maiores ganhos.

Pode-se observar associação positiva e de moderada a alta para todas as combinações de caracteres, sendo as mesmas significativas. As maiores estimativas foram obtidas para os pares de caracteres APM $\times$ VA $(0,80)$ e APM XPG $(0,70)$.

Estas estimativas indicam que dentre os genótipos, os mais produtivos foram aqueles com maior altura e mais tardios. Estes resultados foram 
observados por diversos autores reforçando a associação entre estes caracteres (Freire-Filho, 1988; Shimoya, 1990; Pacova, 1992; Montenegro, 1994; Santos, 1994; Gomes, 1995 e Azevedo-Filho, 1997).

Devido a forte associação entre NDM, APM e PG, a obtenção de genótipos produtivos precoces e de porte alto, torna-se difícil. Isto ocorre porque a seleção é feita para aumentar PG e reduzir NDM, entretanto, a correlação entre estes caracteres é alta e positiva $\left(r_{p}=0,70\right)$.

As correlações de VA com NDM e APM, consideradas altas, revelam que o caráter VA está fortemente associado a genótipos tardios e mais altos. Tais resultados concordam com aqueles observados por Freire-Filho (1988), Pacova (1992) e Gomes (1995).

Conforme esperava-se, as correlações fenotípicas entre VA e PG $\left(r_{p}=0,61\right)$ revelam que $V A$, mesmo sendo um caráter subjetivo que reúne, em uma nota visual, vários caracteres de interesse, pode ser útil na avaliação da produtividade de grãos, uma vez que este caráter é uma resultante de vários outros.

\subsection{Associação entre gerações}

$\mathrm{Na}$ tabela 34 são apresentadas as estimativas das correlações fenotípicas de Spearman $\left(r_{s}\right)$, entre as gerações. As estimativas foram obtidas, para cada tipo de população, com base no desempenho médio das progênies dentro de cada cruzamento.

Torna-se necessário enfatizar que cada geração constitui-se num ambiente diferente, pois deve-se considerar o local, a época de cultivo e o tamanho diferente das parcelas. $E$ ainda, que na geração $F_{7}$ considerou-se a média dos dois locais de cultivo (Anhembi e ESALQ).

As estimativas de $r_{s}$ foram maiores nas populações $\mathrm{PCl}$ e 2 para todos os caracteres avaliados. Com base nos resultados, verifica-se que as correlações 
de produtividade de grãos foram, em geral, muito baixas, sendo consideradas inadequadas ao propósito de predição. Para os caracteres NDM e APM encontraram-se os maiores coeficientes de correlação $\left(r_{s}\right)$.

A variação observada entre as gerações pode ser atribuída às interações simples e múltiplas entre os fatores genótipos, anos, épocas, locais e controle de insetos.

Nos trabalhos realizados por Weiss et al. (1947) onde foram estimadas correlações entre progênies $F_{3}$ e $F_{4}$, os autores observaram que dentre os caracteres avaliados o número de dias para a maturidade apresentou o maior valor de $r(0,50)$. Para altura da planta na maturidade esta estimativa foi de 0,41 e de $-0,18$ para produtividade de grãos. Segundo os autores, isto ocorreu em função da diferença climática nos anos de cultivo.

Gomes (1995) estimou, em soja, a correlação entre progênies $F_{6}$ (em covas) e progênies $F_{7}$ (em fileiras) obtendo valores médios de 0,50 para NDM, 0,27 para APM e VAe -0,07 para PG.

Estes resultados evidenciaram que a predição do comportamento de genótipos para caracteres quantitativos, muito influenciados pelo ambiente, como por exemplo PG, não é confiável quando as condições ambientais são muito variáveis. Sendo assim, para a seleção de genótipos adaptados ao cultivo fora de época, esta deve ser bem definida. $E$ ainda que o ajuste realizado em função do delineamento em blocos aumentados e das várias gerações de endogamia, influenciou nas estimativas obtidas.

Uma maior eficiência na seleção poderá ser obtida quando esta for realizada com base na média dos ambientes não controláveis (anos agrícolas); e nos ambientes controláveis (épocas e locais). Desta forma, um maior progresso poderá ser alcançado com a seleção sendo praticada no local e na época onde se dará o cultivo.

Percebe-se também que, as associações algumas vezes contraditórias, ou não significativas revelam o cuidado que o melhorista deve ter ao avaliar um 
grande número de populações e gerações, evitando assim, generalizações que podem levar a conclusões incorretas. 


\section{CONCLUSÕES}

(a) Maior número de progênies foram selecionadas nos cruzamentos que envolveram o parental IAC-100, e estas apresentaram performance superior, para todos os caracteres avaliados, nos diferentes tipos de populações e gerações de endogamia;

(b) Para a capacidade média de combinação $\left(\mathrm{cmc}_{\mathrm{i}}\right)$ aumentando a expressão dos caracteres nos ambientes avaliados, destacaram-se os parentais: IAC100, Davis e OCEPAR-4;

(c) Dentre os cruzamentos avaliados os mais produtivos são: IAS-5 x IAC-100, Davis $\times$ IAC-100 e OCEPAR-4 x IAC-100;

(d) Alguns dos cruzamentos avaliados apresentam elevada variabilidade, 0 que viabiliza a obtenção de ganhos futuros na seleção de linhagens dentro destes cruzamentos;

(e) O valor agronômico, mesmo sendo um carăter subjetivo, é útil na avaliação da produtividade em genótipos de soja;

(f) A alta correlação entre o número de dias para a maturidade e produtividade de grãos dificulta a obtenção de genótipos precoces e produtivos;

(g) As populações PRIS apresentaram progênies com maior valor agronômico e resistência a percevejos;

(h) Maior progresso de seleção pode ser alcançado quando esta é praticada no ambiente de cultivo. 


\section{REFERÊNCIAS BIBLIOGRÁFICAS}

AGRIANUAL. FNP Consultoria \& Comércio. p.355-388, 1998.

ALL, J.N; BOERMA, H.R.; TODD, J.D. Screening soybean genotypes in the greenhouse for resistance to insects. Crop Science, v.29, n.5, p.1156-1159, 1989.

ALLIPRANDINI, L.F. Potencialidade de cruzamentos quádruplos de soja com ênfase na produtividade de grãos. Piracicaba, 1996. 174p. Tese (Doutorado) - Escola Superior de Agricultura "Luiz de Queiroz", Universidade de São Paulo.

ARUNACHALAM, V. Evaluation of diallel crosses by graphical and combining ability methods. Indian Journal of Genetics and Plant Breeding, v.36, n.3, p.358-66, 1976. 
ASIAN VEGETABLE RESEARCH AND DEVELOPMENT CENTER Antibiosis of PI171444 to Porthesia taiwana and Nezara viridula. Progress Report/1985, p.212-214, 1987 / Resumo em Plant Breeding Abstracts, v.59, n.7, p.693, Jul. 1989.

AZEVEDO-FILHO, J.A. Potencialidade de linhagens experimentais de soja em solos contrastantes na saturação de alumínio. Piracicaba, 1997, 139p. Tese (Doutorado) - Escola Superior de Agricultura "Luiz de Queiroz", Universidade de São Paulo.

BAKER, R.J. Issues in diallel analysis. Crop Science, v.18, n.4, p.533-536, 1978.

BARBOSA, M.H.P. Capacidade combinatória e comparação entre critérios de seleção de clone de batata (Solanum tuberosum L.). Lavras, UFLA, 1996. 141p. Tese (Doutorado)-Universidade Federal de Lavras.

BEACH, R.M.; TODD, J.W. Resistance of the Soybean breeding line GatIR 81-296 to foliar feeding by three Spodoptera $s p$. Journal of Agricultural Entomology, v.4, n.3, p.193-199, 1987. Resumo em Plant Breeding Abstracts, v.58, n.12, p.1202, 1988.

BEACH, R.M.; TODD, J.W.; BAKER, S.H. Antibiosis of four insectresistant soybean genotypes to the soybean looper (Lepidoptera: Noctuidae). Environmental Entomology v.14, n.4, p.531-534, 1985. 
BEARZOTI, E. Comparação entre métodos estatísticos na avaliação de clones de batata em um programa de melhoramento. Lavras, 1994. 128p. Dissertação (Mestrado) - Escola Superior de Agricultura de Lavras.

BELAND, G.L.; HATCHETT, J.H. Expression of antibiosis bollworm in two soybean genotypes. Journal of Economic Entomology, v.69, p.557-560, 1976.

BERNARD, R.L. Two major genes for time of flowering maturity in soybeans. Crop Science, v.11, n.2, p.242-244, 1971.

BHATADE, S.S.; SINGH, C.B.; TIWARI, A. S. Diallel analysis of yield and its components in soybean. Indian Journal Agricultural Science, v.47, n.7, p.322-324, July.1997.

BONATO, E.R. Genética, fontes de genes e reação de genótipos de soja para resistência a doenças, nematóides e insetos pragas. Piracicaba: ESALQ/Departamento de Genética, 1986. 163p. (Monografia).

BONATO, E.R. Herança do tempo para o florescimento e para a maturidade em variantes naturais de soja (Glycine max (L.) Merrill). Piracicaba, 1989. 166p. Tese (Doutorado) - Escola Superior de Agricultura "Luiz de Queiroz", Universidade de São Paulo.

BONETTI, L. P. Distribuição da soja no mundo: origem, história e distribuição. In: MIYASAKA, S.; MEDINA, J. C., (Ed.), A soja no Brasil. Campinas: ITAL, 1981. p. 1-6 
BOWERS JUNIOR, G.R. Registration of Crockett soybean. Crop Science, v.30, p.427, 1990.

BRESSAN, A.A. Comportamento da produção de soja no Brasil. Informe Econômico CNPSo, v.3, n.1, p.27-36, 1997.

BRIM, C.A. Quantitative genetics and breeding. In: CALDWELL, B.E., (Ed.) Soybeans: improvement, production and uses. Madison: American Society of Agronomy, 1973. p.155-186.

BRIM, C.A; COCKERHAM, C.C. Inheritance of quantitative characters in soybeans. Crop Science, v. 1, n.3, p.187-190, May/June, 1961.

BURTON, J.W.; CARVER, B.F. Selection among $S_{1}$ families vs selfed half-sib families in autogamous. Crop Science, v.33, p.21-28, 1993.

BUZZELL, R.I. Inheritance of soybean flowering response to fluorescent-daylenght conditions. Canadian Journal of Genetics and Cytology, v.13, n.4, p.703-707, 1971.

BUZZELL, R.I.; VOLDENG, H.O. Inheritance of insensitivity to long daylenght. Soybean Genetics Newsletter, v.7, p.26-29, 1980.

BYTH, D.E.; WEBER, D.R.; CALDWELL, B.E. Correlated truncation selection for yield in soybean. Crop Science, v.9, n.6, p.6997021969. 
CAMACHO, L.H.M. Varizanzas geneticas y heredabilidad de caracteristicas vegetativas y reproductivas de la soya Glycine $\max ($ L.) Merr. Acta Agronomica, v.21, n.4, p.145-152, 1971.

CAMPO, C.B.H.; KIIHL, R.A.S.; ALMEIDA, L.A.; OLIVEIRA, E.B.; BAYS, I.A. Estudo da metodologia para avaliar resistência de genótipos de soja a percevejos. In: CONGRESSO BRASILEIRO DE ENTOMOLOGIA, 10., Rio de Janeiro, 1986. Resumos. Porto Alegre: SEB, 1986. p.167.

CARVALHO, L.R. de. Blocos casualizados com tratamentos comum: uma aplicação ao melhoramento genético de soja, Piracicaba, 1991. 82p. Dissertação (Mestrado). Escola Superior de Agricultura "Luiz de Queiroz", Universidade de São Paulo.

CASTIGLIONI, E.A.; VENDRAMIM, J.D. Efeitos de genótipos de soja no desenvolvimento de Anticarsia gemmatalis Hubnerr( Lepidoptera: Noctuidae) Anais da Sociedade Entomológica do Brasil, v.25, n.3, p.411-416, 1996.

CASTIGLIONI-ROSALES, E.A. Aspectos biológicos e não preferência para alimentação e oviposição de Anticarsia gemmatalis Hubner 1818, em genótipos de soja, Glycine max (L.) Merril. Piracicaba, 1990. 160p. Dissertação (Mestrado) Escola Superior de Agricultura de "Luiz de Queiroz", Universidade de São Paulo.

CASTRO, P.R.C. Avaliação da infestação natural de pragas das folhas em cultivares de soja. Anais da ESALQ, v.38, p.351$357,1981$. 
CAVINESS, C.E.; PRONGSIRIVATHANA, C. Inheritance and association of plant height and its components in soybean cross. Crop Science, v.8, p.221-224, 1968.

CECON, P.R.; MORAIS, A.R. de; SEDIYAMA, C.S. Obtenção da herdabilidade e das correlações genotípicas e fenotípicas e de ambiente nas gerações $F_{2}$ e $F_{3}$ de cruzamentos fatoriais em soja. Pesquisa Agropecuária Brasileira, v.28, n12, p13991406, dez. 1993.

CECON, P.R.; SEDIYAMA, C.S.; REGAZZI, A.J.; SEDIYAMA, T. Análise das gerações $F_{2}$ e $F_{3}$, para estimar variâncias aditivas, de dominâncias e de ambiente, em um sistema fatorial de cruzamentos em soja. Revista Ceres, v.32, n.184, p.470-487, 1985.

CIVIDANES,F.J.; ATHAYDE, M.L.F.; SABUGOSA, E.T. Levantamento populacional de artrópodos associados a cultivares de soja semeados em diferentes densidades. Revista de Agricultura, v.71, n.2, p.243-250, 1996.

CLARK, W.J.; HARRIS, F.A.; MAXWELL, F.G.; HARTWIG, E.E. Resistance of certain soybean cultivars to bean leaf beetles, striped blister beetle, and bollworm. Journal of Economic Entomology, v.65, n.6, p.1669-1672, 1972.

COOPER, T.C.; HAMMOND, R.B. Registration of insect-resistant soybean germplasm line HC83-193. Crop Science, v.35, p.595, 1995. 
CORSO, I.C. Constatação do agente causal da mancha de leveduras em percevejos que atacam a soja no Paraná. In: Seminário Nacional Nacional de Pesquisa em Soja, 3., Campinas, 1984. Anais. Londrina: EMBRAPA-CNPSo, 1984. p. 152-157.

CRISWELL, J.G.; HUME, D.J. Variation in sensitivity to photoperiod among early maturing soybean strains. Crop Science, v.12, p.657-660, 1972.

CROISSANT, G.L.; TORRIE, J.H. Evidence of nonadditive effects and linkage in two hybrid populations of soybeans. Crop Science, v11, n.5, p.675-677, Sep./Out. 1971.

CRUZ, C.D.; REGAZZI, A.J. Modelos biométricos aplicados ao melhoramento genético. Viçosa: UFV, 1994. 390p.

CRUZ, C.D.; VENCOVSKY, R. Comparação de alguns métodos de analise dialélica. Revista Brasileira de Genética, v.12, n.2, p. 425-438, 1989.

DAUGHERTY, D.M.; NEUSTADT, M.H.; GEHRKE, C.W.; CAVANAH, L.E.; WILLIAMS, L.F.; GREEN, D.E. An evaluation of damage to soybeans by brown and green stink bugs. Journal of Economic Entomology, v.57, n.10, p.719-722, 1964.

DESTRO, D. Capacidade de combinação de genótipos de soja (Glycine max (L.) Merrill) apropriados para o consumo humano. Piracicaba, 1991. 158p. Tese (Doutorado) - Escola Superior de Agricultura "Luiz de Queiroz", Universidade de São Paulo. 
DUARTE, J.B. Problemas relacionados ao uso de delineamento em blocos aumentados num programa de melhoramento de soja. Piracicaba, 1997. Plano Tese- Escola Superior de Agricultura "Luiz de Queiroz", Universidade de São Paulo

ELDEN, T.C.; BERNARD, R.L.; KOGAN, M.; HELM, C.G.; BLEDSOE, L.W. Registration of three group III maturity insect-resistant soybean germplasm lines: MBB80-133, L86K-73, and L86K-96. Crop Science, v.32, p.1082-1083, 1992

ELDEN, T.C.; SCHILLINGER, J.A.; ALMEIDA, L.A. Field and laboratory selection for resistance in soybean to the mexican bean beetle. Environmental Entomology v.3, n.5, p.785-788, 1974.

FALCONER, D.S. Introduction to quantitative genetics. 3.ed. Harlow: Longman, 1989. 438p.

FARIAS NETO, J.T. Potencialidade de progênies F4:3 e F5:3 derivadas de cruzamentos em cadeia para produtividade de óleo em soja. Piracicaba, 1995. 153p. Tese (Doutorado) - Escola Superior de Agricultura "Luiz de Queiroz"/Universidade de São Paulo.

FATMI, A.; WAGNER, D.B.; PFEIFFER, T.W. Intermating schemes used to synthesize a population are equal in genetic consequences. Crop Science, v.32, n.1, p.89-04, 1992.

FEDERER, W. T. Augment (or hoonuiaku) designs. Hawaiian Planters' Record, v.55, p.191-208, 1956. 
FEDERER, W. T. Augmented designs with one way elimination of heterogeneity. Biometrics, v.17, n.3, p.477-73, Sep.1961.

FEHR, W. R. Breeding methods for cultivar development. In: WILCOX, J. R., (Ed.) Soybeans; improvement, productions and uses. 2.ed. Madison: ASA/CSSA/WWWQ, 1987. p. 249-93.

FERREIRA, B.S.C.; PANIZZI, A.R. Percevejos-pragas da soja no norte do Paraná: abundância em relação a fenologia da planta e hospedeiros intermediários. In: Seminário Nacional de Pesquisa de Soja, 2., Londrina, 1981. Anais. Londrina: EMBRAPA/CNPSo, 1981. V.2, p.140-151.

FERREIRA, P. E. On Jinks-Hyman's analysis of half diallels. Revista Brasileira de Genética, v.8, n.1, p.149-155, 1985.

FREIRE FILHO, F.R. Análise genética de um dialelo entre genótipos precoces de soja (Glycine max (L.) Merrill). Piracicaba, 1988. 224p. Tese (Doutorado) - Escola Superior de Agricultura "Luiz de Queiroz", Universidade de São Paulo.

GARDNER, C. O; EBERHART, S. A Analysis and interpretation of variety cross diallel and related population. Biometrics. v.22, n.3, p. 439-452.

GATES, C. E.; WEBER, C. R.; HORNER, T. W. A linkage study of quantitative characters in soybean cross. Agronomy Journal, v.52, n.1, p.45-49, Jan. 1960. 
GAZZONI, D.L.; TUTIDA, F. Efeito de genótipos resistentes e suscetiveis sobre a biologia da lagarta da soja (Anticarsia gemmatalis Huber). Pesquisa Agropecuária Brasileira, v.31, n.10, p.709-14, 1996.

GILIOLI, J. L.; SEDIYAMA, T.; FONSECA JÚNIOR, N. Herança do número de dias para a floração em quatro mutantes naturais em soja. In:SEMINÁRIO DE PESQUISA DA SOJA, 3.,Campinas, 1984. Anais. Londrina: EMBRAPA/CNPSo,1984. p.323-337.

GILMAN, D.F.; MCPHERSON, R.M.; NEWSOM, L.D.; HERZOG, D.C.; WILLIAMS, C. Resistance in soybeans to southern green stink bug. Crop Science, v.2, n.3, p.573-576, 1982.

GILMAN, D.F.; SMITH, C.M.; NEWSOM, L.D. Screening soybeans for stinkbug resistance. Louisiana Agriculture, V.24, n.1, p. 12$13,1980$.

GOMES, R.L.F. Análise genética de progénies $F_{6}$ e $F_{7: 6}$ de soja obtidas de cruzamentos dialélicos. Piracicaba, 1995, 139p. Tese (Doutorado) - Escola Superior de Agricultura "Luiz de Queiroz", Universidade de São Paulo.

GRIFFING, B. Concept of general and specific combining ability in relation to diallel crossing sistems. Australian Journal of Biological Siences, v.9, p.463-493, 1956. 
HAMMOND, R.B.; COOPER, R.L. Development and antibiosis of released soybean germplasm lines resistant to Mexican Bean Beetle. Journal of Economic Entomology, v.82, n.1, p.259-263, 1989.

HANSON, W. D.; PROBST, A H.; CALDWELL, B. E. Evaluation of a population of soybean genotypes with implications for improving self-pollinated crops. Crop Science, v.7, n.2. p.99103, Mar./Apr. 1967.

HANSON, W. D.; WEBER, C. R. Analysis of genetic variability from generation of plant-progeny lines in soybeans. Crop Science, v. 2, n.1, p.63-67, Jan./Feb. 1962.

HANSON, W. D.; WEBER, C. R. Resolution of genetic variability in self-pollinated species with na aplication to soybean. Genetics, v.46, n.11, 1425-1434, Nov. 1961.

HARTWIG, E.E.; KENTY, M.M.; LAMBERT, L.L. Registration of soybean germplasm line D86-3429, resistant to root knot nematodes and foliar feeding insects. Crop Science, v.34, p. $1135,1994$.

HARTWIG, E.E.; KIIHL, R.A.S. Identification and utilization of a delayed flowering caracter in soybeans for short-day conditions. Field Crops Research, v.2, p. 145-51, 1979. 
HARTWIG, E.E.; KILEN, T.C. Breeding soybeans resistant to foliar feeding insects In: CONFERÉNCIA MUNDIAL DE INVESTIGACION EN SOJA, 4., Buenos Aires, 1989. Proceedings. Buenos Aires: Association Argentina de la Soja, 1989. p. $2035-2045$.

HARTWING, E.E.; LAMBERT, L.; KILEN, T.C. Registration of "Lamar" soybean. Crop Science, v.30, p.231, 1990.

HATCHETT, J.H.; BELAND, G.L.; HARTWIG, E.E. Leaf-feeding resistance to bollworm and tobacco budworm in three soybean plant introductions. Crop Science, v.16, n.2, p.277-280, 1976.

HATCHETT, J.M.; BELAND, G.L.; KILEN, T.C. Identification of multiple insect resistant soybean lines. Crop Science, v.19, n.4, p.557-559, 1979.

HAYMAN, B. I. The analysis of variance of diallel tables. Biometrics, v.10, n.2, p.235-244, 1954a.

HAYMAN, B. I. The theory and analysis of diallel crosses. Genetics, v.39, n.6, p.789-809, 1954b.

HICKS, D.R. ; PENDLETON. Effect of the foliar bud removal on performance of soybean. Crop Science, v.9, p.435-437, 1996.

HINSON, K. Use a long juvenile trait in cultivar development. In: CONFERENCIA MUNDIAL DE INVESTIGACION EN SOJA, 4., Buenos Aires, 1989. Proceedings. Buenos Aires: Association Argentina de la Soja, 1989. p.983-987. 
HIROMOTO, D.M.; VELLO, N.A. The genetic base of Brazilian soybean (Glycine max (L.) Merrill) cultivars. Revista Brasileira Genetica, v.9, n.2, p.295-306, 1986.

HOFFMAN-CAMPO, C.B.; MAZZARIN, R.M.; LUSTOSA, P.R. Mecanismos de resistência de genótipos de soja: Teste de não preferência para Anticarsia gemmatalis Huber, 1818 ( Lepdoptera: Noctuidae) Pesquisa Agropecuária Brasileira, v. 29, p.513-519,1994.

HORNER, T. W.; WEBER, C.R. Theoretical and experimental study of self fertilized populations. Biometrics, v.12, n.4, p.404-414, Dec. 1956.

HYMOWITZ, T. On the domestication of soybean. Economic Botany, v.24, n.4. p.408-421. Oct./Dec.1970.

JINKS, J. L.; HAYMAN, B. I. The analysis of diallel crosses. Maize Genetics Cooperation Newsletter, v.27, p.48-54, 1953.

JONES JUNIOR., W.A.; SULLIVAN, M.J. Soybean resistance to the Southern green stink bug, Nezara viridula. Journal of Economic Entomology, v.72, n.4, p.628-632, 1979.

JONES JUNIOR., W.A.; SULLIVAN, M.J. Suscetibility of certain soybean cultivars to damage by stink bugs. Journal of Economic Entomology, v.71, n.3, p.534-536, 1978.

JONES, R. M. Analysis of variance of the half diallel table. Heredity, v.20, n.1, p.117-121, 1965. 
KAW, R.N.; MENON, P.M. Combining ability for development traits in soybean. Indian Journal of Genetics \& Plant Breeding, v.41, n.3, p.303-308, 1981.

KEARSEY, M. J. Biometrical analysis of a random mating population. A comparison of five experimental designs. Heredity, v.20, n.2, p.205-235, 1965.

KENWORTHY, W.J. Strategies for introgressing exotic germplasm in breeding programs. In: WORLD SOYBEAN RESEARCH CONFERENCE, 2., North Caroline, 1979. Proceedings. Colorado: Westview Press, 1980. p.217-223.

KENWORTHY, W.J.; BRIM, C.A. Recurrent selection for yield in soybeans I. Seed yield. Crop Science, v.19, n.3, p.315-318. May/June 1979.

KESTER, K.M.; SMITH, C.M.; GILMAN D.F. Mechanisms to resistance in soybean genotype PI 171444 to the Southern Green Stink Bug, Nezara viridula (2.). Environmental Entomology, v.13, n.5, p.1028-1215, 1984.

KIIHL, R. A S.; ALMEIDA, L. A. Situação atual e perspectivas do melhoramento genético da soja no Brasil. In: SIMPÓSIO SOBRE A CULTURA E PRODUTIVIDADE DA SOJA, 1., Piracicaba, 1991. Anais; editado por G.M.S. Câmara; J. Marcos Filho ; E.A.M. Oliveira. Piracicaba: FEALQ, 1992. p. 38-40. 
KIIHL, R.A.S. Inheritance studies of two characters in soybean (Glycine max (L.) Merrill); I. resistance to soybean mosaic virus; II. Late flowering under short-day conditions. Mississipi, 1976. 56p. Thesis (PhD) Mississipi State University.

KIIHL, R.A.S.; GARCIA, A. The use of the long-juvenile trait in breeding soybeans cultivars. In: CONFERENCIA MUNDIAL DE INVESTIGACION EN SOJA, 4., Buenos Aires, 1989. Proceedings. Buenos Aires: Association Argentina de la Soja, 1989. p.994-1000.

KILEN, T.C.; HATCHETT, J.H.; HARTWIG, E.E. Evaluation of early generation soybeans for resistance to soybean looper. Crop Science, v.17, n.3, p.397-398, 1977.

KILEN, T.C.; LAMBERT, L. Evidence for different genes controlling insect resistance in three soybean genotypes. Crop Science, v.26, n5, p.869-871, 1986.

KILEN, T.C.; LAMBERT, L. . Registration of three glabrous and three dense pubescent soybean germplasm lines susceptible (D88-5320, D88-5295), resistant (D90-9216, D90-9220) to foliarfeeding insects. Crop Science, v.33, p.215, 1993.

KILPATRICK, R.A.; HARTWIG, E.E. Fungus infection of soybean seed as inflenced by stink bug injury. Plant Disease Reporter, v.39, n.2, p.177-180,1955. 
KOGAN, M. Feeding and nutrition of insects associated with soybean. 1. Growth and development of the Mexican bean beetle; Epilachna varivestis, on artificial media. Annals of Entomological Society of America, v.64, n.5, p1044-1050, 1972.

KOGAN, M. Plant resistance in soybean insect control. In: CONFERENCIA MUNDIAL DE INVESTIGACION EN SOJA, 4., Buenos Aires, 1989. Proceedings. Buenos Aires: Association Argentina de la Soja, 1989. p.1519-1525.

KOGAN, M.; TURNIPSEED, S.G.; SHEPARD, M.; OLIVEIRA, E.B.; BORGO, A. Pilot insect pest management program for soybean in Southern Brazil. Journal of Economic Entomology, v.70, n.5, p.659-663, 1977.

KWON, S. H.; TORRIE, J. H. Heritability of and interrelationships among traits of two populations. Crop Science, v.4, p.196198,1964 .

LAÍNEZ-MEJÍA, J.R. Implicações da interação genótipos $x$ ambientes na seleção de progênies de soja com ênfase nas produtividades de grãos e óleo. Piracicaba, 1996. 145p. Tese (Doutorado) - Escola Superior de Agricultura "Luiz de Queiroz", Universidade de São Paulo.

LAMBERT, L.; KILEN, T.C. Influence of three soybean plant genotypes and their $F_{1}$ intercrosses on the development of five insects species. Journal of Economic Entomology, v.77, n.3, p.622-625, 1984b. 
LAMBERT, L.; KILEN, T.C. Insect resistance factor in soybean PI's 229358 and 227687 demonstrated by grafting. Crop Science, v.24, n.1, p.163-167, 1984a.

LAMBERT, L.; KILEN, T.C. Multiple insect resistance in several soybean genotypes. Crop Science, v.24, n.5, p.887-890, 1984c.

LAYTON, M.B.; BOETHEL, D.J.; SMITH, C.M. Resistance to adult bean leaf beetle and banded cucumber beetle in soybean. Journal of Economic Entomology, v.80, n.1, p.151-155, 1987.

LEFFEL, R. C.; WEISS, M. G. Analysis of diallel crosses among ten varieties of soybeans. Agronomy Journal, v.50, n.9, p.528534, Sep. 1958.

LEFFEL, R. C.; HANSON, W. D. Early generation testing diallel crosses of soybeans. Crop Science, v.1, p.169-174, May/June. 1961.

LINK, D.; COSTA, E.C. Danos causados por besouros crisomelídeos em soja. Revista do Centro Ciências Rurais, v.8, n.3, p.245-250, 1978.

LINK, D.; COSTA, E.C. Danos causados por besouros crisomelídeos em soja. In: SEMINÁRIO NACIONAL DE PESQUISA DE SOJA, 2., Brasília, 1981a. Anais. Londrina: EMBRAPA/CNPSo, 1982. p.151-158. 
LINK, D.; COSTA, E.C. Importância da duração do subperíodo floração-frutificação, em soja, no dano causado por Nezara viridula (L.). Revista do Centro Ciências Rurais, v.4, n.3, p.243-246, 1974.

LINK, D.; ESTEFANEL, V. Influência do número de sementes por legume e de legumes por plantas sobre o nivel de dano de pentatomídeos em soja. Revista do Centro Ciências Rurais, v.12, p.109-113, 1982.

LINK, D.; ESTEFANEL, V.; SANTOS, O.S. dos. Efeito de cultivares e do local sobre o nivel de dano de Pentatomidae em soja. In: SEMINÁRIO NACIONAL DE PESQUISA DE SOJA, 2., Brasília, 1981. Anais. Londrina: EMBRAPA/CNPSo, 1982. p.79-83.

LOPES, A.C.A. Potencialidade de cruzamentos óctuplos de soja com ênfase na produtividade de grãos. 1996. 102p. Dissertação (Mestrado) - Escola Superior de Agricultura "Luiz de Queiroz", Universidade de São Paulo.

LOURENÇÃO, A.L.; COSTA, A.S.; MIRANDA, M.A.C. Sources of resistance to insect pest and virus vector in the soybean germoplasm. In: CONFERÊNCIA MUNDIAL DE INVESTIGACION EN SOJA, 4., Buenos Aires, 1989. Proceedings. Buenos Aires: Association Argentina de la Soja, 1989, p.1578-1581.

LOURENÇÃO, A.L.; MIRANDA, M.A.C. Resistência de soja a insetos. I. Comportamento de linhagens e cultivares em relação a Epinotia aporema (WALS.) (Lepidoptera: Tortricidae). Bragantia, v.42, p.203-209, 1983. 
LOURENÇÃO, A.L.; MIRANDA, M.A.C. Resistência de soja a insetos. V. Preferência para alimentação de adultos de Diphaulaca viridipennis. Clark, 1865 em cultivares e linhagens. Bragantia, v.45, n.1, p.37-44, 1986.

LOURENÇÃO, A.L.; MIRANDA, M.A.C. Resistência de soja a insetos: IAC 78-2318, linhagem com resistência múltipla. Bragantia, v.46, n.1, p.65-72, 1987.

LOURENÇÃO, A.L.; MIRANDA, M.A.C. de; NAGAI, V. Resistência de soja a insetos. VII. Avaliação de danos de percevejos em cultivares e linhagens. Bragantia, v.46, n.1, p.45-47, 1987.

LOURENÇÃO, A.L.; MIRANDA, M.A.C.; PEREIRA, J.C.V.N.A.; AMBROSANO, G.M.B. Resistência de soja a insetos: $X$. comportamento de cultivar e linhagens em relação a percevejos e desfolhadores. Anais da Sociedade Entomológica do Brasil, v. 26, n.3, p. $543-550,1997$.

LOURENÇÃO, A.L.; ROSSETTO, C.J.; MIRANDA, M.C.A. Resistência de soja a insetos. IV. Comportamento de cultivares e linhagens em relação a Hedilepta indicata (Fabr.). Bragantia, v.44, n.1, p.149-157, 1985.

LUEDDERS, V.D. Genetic improvement in yield of soybeans. Crop Science, v.17, n.6, p.971-972, Nov./Dec. 1977.

LUEDDERS, V.D.; DICKERSON, W.A. Resistance of selected soybean genotypes and segregating populations to cabbage looper feeding. Crop Science, v.17, n.3, p.395-397, 1977. 
MARCOS, E. A. Análise de grupos de experimentos em blocos completos aumentados através do pacote computacional SAS. Piracicaba, 1994. 91p. Dissertação (Mestrado) - Escola Superior de Agricultura "Luiz de Queiroz", Universidade de São Paulo.

MASCARENHAS, H.A.A.; MIRANDA, M.A.C.; LELIS, L.G.L.; BULISANI, E.A.; BRAGA, N.R.; PEREIRA, J.C.V.N.A. Haste verde e retenção foliar em soja por deficiência de potássio. Boletim Técnico Instituto Agronômico de Campinas, v.119, p.15. 1988.

MASSARIOL, A.A.; RAMIRO, Z.A.; CALCAGNOLO, G. Insetos observados na cultura da soja no Estado de São Paulo. 0 Biológico, v.45, p.85-87, 1979.

McBLAIN, B.A. Studies of soybean maturity genes. Urbana, 1984. 92p. (Ph-D-University of Illinois). Apud Dissertation Abstracts International, B, Ann Arbor, v.45, n.11, p.3423B, 1985.

McBLAIN, B.A.; BERNARD, R.L. A new gene affecting the time of flowering and maturity in soybeans. Journal of Heredity, v.78, n.3, p.160-162, 1987.

MEBRAHTU, T.; KENWORTHY, W.J.; ELDEN, T.C. Genetic study of resistance to the Mexican bean beetle in soybean lines. Journal of Genetic \& Breeding, v.44, n.1, p.7-12, 1990. 
MIRANDA FILHO, J. B.; GERALDI, I. O. An adapted model for the analysis of partial diallel crosses. Revista Brasileira de Genética, v.7, n.4, p. 677-688, 1984.

MIRANDA, M.A.C. de; BULISANI, E.A.; MASCARENHAS, H.A.A.; LOURENÇÃO, A.L. Potencialidade do emprego de supergenes no melhoramento da soja. O Agronômico, v.39, n.3, p.287-297, 1987.

MIRANDA, M.A.C. de; MIYASAKA, S.; MASCARENHAS, H.A.A.; ROSSETTO, C.J. Melhoramento de cultivares. In: MIYASAKA, S.; MEDINA, J.C. A soja no Brasil, Campinas: ITAL, 1981. p.311-324.

MIRANDA, M.A.C. de; ROSSETTO, C.J.; ROSSETTO D.; BRAGA, N.R.; MASCARENHAS, H.A.A.; TEIXEIRA, J.P.F.; MASSARIOL, A. Resistência de soja a Nezara viridula (L.) e Piezodorus guildinii (WESTW.) em condições de campo. Bragantia, v.38, p. $181-188,1979$.

MOMENTÉ, V. G. Comparação entre diferentes tipos de familias clonais para o melhoramento genético da batata (Solanum tuberosum L.). Lavras, 1994. 83p. Dissertação (Mestrado) Escola Superior de Agricultura de Lavras.

MONTAÑO-VELASCO, J. C. Análise genética de progênies F3 de soja derivadas de cruzamentos em cadeia com ênfase na produção de óleo. Piracicaba, 1994. 115p. Tese (Doutorado) Escola Superior de Agricultura "Luiz de Queiroz", Universidade de São Paulo. 
MONTENEGRO, E. E. Estimativas de parâmetros genéticos, no verão e no inverno, em cruzamentos entre cultivares de soja (Glycine max (L.) Merrill), divergentes quanto a juvenilidade. Viçosa, 1994. 97p. Dissertação (M.S.) - Universidade Federal de Viçosa.

MOREIRA, R.M.P. Predição do comportamento de cruzamentos dialélicos de soja avaliados na geração $F_{3}$ em cultivo de inverno. Piracicaba, 1992. 96p. Dissertação (Mestrado)-Escola Superior de Agricultura "Luiz de Queiroz", Universidade de São Paulo.

MURTY, B. R.; ANAND, I. J. Combining ability and genetic diversity im some varieties of Linum usitatissimum. Indian Journal of Genetics and Plant Breeding, v.26, n.1, p.21-36, 1966.

NASS, L.L. Potencialidade de genótipos de soja (Glycine max (L.) Merrill) para o cultivo de inverno avaliado por cruzamentos dialélicos. Piracicaba, 1989. 112p. Dissertação (Mestrado)Escola Superior de Agricultura "Luiz de Queiroz", Universidade de São Paulo.

NASSAR, R. F. Effect of correlated gene distribuition due to sampling on the diallel analysis. Genetics, v.52, n.1, p.9-20, 1965.

NOGUEIRA, M. C. S. Análise conjunta para experimentos em blocos casualizados completos aumentados. Piracicaba, 1976. 49p. Dissertação (Mestrado) - Escola Superior de Agricultura "Luiz de Queiroz", Universidade de São Paulo. 
OLIVEIRA, A C. Experimentos em reticulado qudrado com alguns tratamentos adicionais em cada bloco (análise com recuperação da informação interblocos). Pesquisa Agropecuária Brasileira, 1990. v.25, n.3, p.289-298.

OLIVEIRA, A C.; BARBIN, D. Experimentos em reticulado quadrado com alguns tratamentos comuns adicionados em cada bloco (análise intrablocos). Pesquisa Agropecuária Brasileira, 1988, v.23, n.7, p.717-723, 1988.

OLIVEIRA, A. C. Análise intrablocos de experimentos em blocos imcompletos parcialmente balanceados com alguns tratamentos comuns em cada bloco. Piracicaba, 1986. 153p. Tese (Doutorado) - Escola Superior de Agricultura "Luiz de Queiroz", Universidade de São Paulo

OLIVEIRA, E.B.; HERZOG, D.C.; STIMAC, J.L. Efeito de dois genótipos de soja, resistente e suscetível, na população de Anticarsia gemmatalis Hübner e incidência de Nomurae rileyi (Farlow) Sawson. Anais da Sociedade Entomológica do Brasil, v.13, n.2, p.281-294, 1984.

OLIVEIRA, L.J.; HOFFMANN-CAMPO, C.B.; MAZZARIN, R.M. Aspectos biológicos e nutricionais de Anticarsia gemmatalis Hub (Lepidoptera: Noctuidae) em diversos genótipos de soja. Anais da Sociedade Entomológica do Brasil, v.22, p.547-552, 1993. 
PACOVA, B.E.V. Análise genética de progénies segregantes de soja apropriada para o consumo humano. Piracicaba, 1992. 217p. Tese (Doutorado) - Escola Superior de Agricultura "Luiz de Queiroz", Universidade de São Paulo

PAINTER, R.H. Insect resistance in crop plants. New York: MacMillan, 1951. 520p.

PANIZZI, A.R.; CORREA, B.S.; GAZZONI, D.L.; OLIVEIRA, E.B.; NEWMAN, G.G.; TURNIPSEED, S.G. Insetos da soja no Brasil. Boletim Técnico EMBRAPA-CNPSo, v.1, p.20, 1977.

PANIZZI, A.R.; PANIZZI, M.C.C.; BAYS, I.A.; ALMEIDA, L.A. Danos por percevejos em genótipos de soja com semente pequena. Pesquisa Agropecuária Brasileira, v.21, n.6, p.571-577, 1986.

PANIZZI, A.R.; SLANSKY JÚNIOR, F. Review of phytophagous pentatomids (Hemiptera: Pentatomidae) associated with soybean in the Americas. Florida Entomologist, v.68, n.1, p. 184-214, 1985.

PASCAL II, E.H.; WILCOX, J.R. Heterosis and combining ability in exotic soybean germplasm. Crop Science, v.15, n.3, p.344$349,1975$.

PASCHAL II, E.H.; ROGERS, C.E. Soybean breeding for resistance to foliage feeding arthropods. In: HARRIS, M.K., (Ed.) Biology and breeding for resistance to artropod and pathogens in agricultural plants. College Station: Texas A \& M Universsity, 1979. p.390-397. 
PINHEIRO, J.B. Dialelo parcial entre parentais de soja resistentes e suscetíveis a insetos. Piracicaba, 1993. 143p. Dissertação (Mestrado) - Escola Superior de Agricultura "Luiz de Queiroz", Universidade de São Paulo.

PINHEIRO, J.B.; ROSSETTO, C.J.; ARTIAGA, S.R.R.; GALLO, P.B.; VELLO, N.A. Avaliação da resistência de soja a percevejos em cruzamentos envolvendo o cultivar IAC-100 In: CONGRESSO BRASILEIRO DE ENTOMOLOGIA, 16, Salvador, 1997. Resumos. Salvador : Sociedade Entomológica do Brasil, 1997. p. 335.

PINHEIRO, J.B.; VELLO, N.A. Ocorrência de Gynandrobrotica caviceps adumbrata Bech. (COLEOPTERA:GALERUCINAE) na cultura da soja em Piracicaba, SP. Scientia Agricola, v.54, n.3, p.251-253, 1997.

PORTO, M.P. Resistência de soja a insetos pragas. In: VERNETTI, F.J. (Ed.) Soja genética e melhoramento, Campinas: Fundação Cargill, 1983. v.2, p.839-873.

PRADO, L.C. Perspectivas para o melhoramento de linhagens hjomozigóticas de soja, com ênfase em produção de grãos e teor de proteína. Piracicaba, 1994. 128p. Dissertação (Mestrado) - Escola Superior de Agricultura "Luiz de Queiroz", Universidade de São Paulo.

RAMALHO, M. A P.; VENCOVSKY, R. Estimação dos componentes de variência genética em plantas autógamas. Ciência e Prática, v.2, n.2, p.117-140, Jul./Dez. 1978. 
RAMALHO, M.A.P.; SANTOS, J.B.; ZIMMERMANN, M.L.O. Genética Quantitativa em plantas autógamas; aplicações ao melhoramento do feijoeiro. Goiânia: UFG, 1993, cap.3, p.29-77; Componentes de médias, variâncias e covariâncias.

REZENDE, J.A.M.; MIRANDA, M.A.C. de; MASCARENHAS, H.A.A. Comportamento de cultivares de soja em relação à área foliar comida por lagartas das folhas. Bragantia, v.39, p.161-165, 1980a.

REZENDE, J.A.M.; ROSSETTO, C.J.; MIRANDA, M.A.C. Comportamento de populações parentais e $F_{1}$ de soja em relação a Colaspis sp e Diabrotica speciosa (GERMAR, 1824). Bragantia, v.39, p.15-19, 1980 b.

ROESSING, A.C. Situação mundial das oleaginosas. Informe Econômico CNPSo, v.3, n.1, p.5-26, 1997.

ROSE, J.L.; BUTLER, D.G.; RYLEY, H.J. Yield improvment in soybeans using recurrent selection. Australian Journal Agricultural Research, v.43, n.1, p.135-144, 1992.

ROSSETTO, C.J. Breeding for resistance to stink bugs. In: CONFERENNCIA MUNDIAL DE INVESTIGACION EN SOJA, 4., Buenos Aires, 1989. Proceedings. Buenos Aires: Association Argentina de la Soja, 1989. p.2046-2060. 
ROSSETTO, C.J.; GALLO, P.B.; RAZERA, L.F.; BORTOLETTO, N.; IGUE, T.; MEDINA, P.F.; TISSELLI FILHO, O.; AQUILERA, V.; VEIGA, R.F.A.; PINHEIRO, J. B. Mechanisms of resistance to stink bug complex in the soybean cultivar IAC-100. Anais Sociedade Entomológica do Brasil, v.24, n.3, p.517-522, 1995.

ROSSETTO, C.J.; IGUE, T.; MIRANDA, M.A.C. de; LOURENÇÃO, A.L. Resistência de soja a insetos: VI. Comportamento de genótipos em relação a percevejos. Bragantia, v.45, n.2, p.317-322, 1986.

ROSSETTO, C.J.; LARA, F.M. Diluição de dano, mecanismo de pseudoresistência. In: CONGRESSO BRASILEIRO DE ENTOMOLOGIA, 13., Recife, 1991. Resumos, Sociedade Entomolócoa do Brasil, 1991. P.535.

ROSSETtO, C.J.; LOURENÇÃO, A.L.; IGUE, T.; MIRANDA, M.A.C. Picadas de alimentação de Nezara viridula em cultivares e linhagens de soja de diferentes graus de suscetibilidade. Bragantia, v.40, p.109-114, 1981a.

ROSSETTO, C.J.; LOURENÇÃO, A.L.; MIRANDA, M.A.C. de; IGUE, T. Resistência de soja a insetos. II. Testes de livre escolha entre a linhagem IAC 73-228 e o cultivar Paraná, infestados por Nezara viridula (L.) em telado. Bragantia, v.43, n.1, p.141-153, 1984. 
RossetTo, C.J.; MIRANDA, M.A.C. de; LINK, D.; REZENDE, J.A.M.; LOURENÇÃO, A.L.; MASCARENHAS, H.A.A.; MIYASAKA, S. Cultivares resistentes aos insetos pragas. In: MIYASAKA, S.; MEDINA, J.C. A soja no Brasil, Campinas: ITAL, 1981b. p.311-324.

ROSSETTO, C.J.; NAGAI, V.; IGUE, T.; ROSSETTO, D.; MIRANDA, M.A.C. Preferência de alimentação de adultos de Diabrotica speciosa (GERMAR) e Ceratoma arcuata (Oliv.) em variedades de soja. Bragantia, v.40, p.179-183, $1981 \mathrm{c}$.

ROSSETTO, C.J.; TISSELLI FILHO, O.; RAZERA, L.F.; GALLO, P.B.; PEDRO JUNIOR, M.J.; CAMARGO, M.B.P.; IGUE, T.; TEIXEIRA, J.P.F. Integration of resistant cultivar and date of planting for cultivation of soybean with reduced use of inseticides. In: CONFERÊNCIA MUNDIAL DE INVESTIGACION EN SOJA, 4., Buenos Aires, 1989. Proceedings. Buenos Aires: Association Argentina de la Soja, 1989. p.1582-1587.

ROSSETTO, D.; NAGAI, V. Ensaio de livre escolha para o coleoptero Colaspis sp em seis variedades de soja. Bragantia, v.39, p.195-198, 1980.

RUFENER II, G.K.; ST. MARTIN, S.K.; COOPER, R.L.; HAMMOND, R.B. Genetics of antibiosis resistance to mexican bean beetle in soybean. Crop Science, v.29, n.3, p.618-622, 1989. 
RUFENER, G.K., II. A genetic and biochemical study of the antibiosis mechanism of host plant resistance in soybeans to the mexican bean beetle. Dissertation abstracts international. B, v.48, n.9, p.2506, 1988. Apud Plant Breeding Abstracts, v.58, n.8, p.776, Aug. 1988.

RUFENER, G.K.; HAMMOND, R.B.; COOPER, R.L.; MARTIN, S.K. St. Larval antibiosis screening technique for mexican bean beetle resistance in soybean. Crop Science,. v.27, n.3, p.598600, 1987.

RUFENER, G.K.; HAMMOND, R.B.; COOPER, R.L.; ST. MARTIN, S.K. Mexican bean beetle (Coleoptera:Coccinellidae) development on resistant and suscetible soybeans lines in the laboratory and relationship to field selection. Journal of Economic Entomology, v.79, n.5, p.1354-1358, 1986.

SANTOS, C. A F. Análise de trilha e estimativas de parâmetros genéticos em progênies F6 de um cruzamento de soja (Glycine mas (L.) Merrill). Viçosa, 1994. 71p. Dissertação (M.S.) Universidade Federal de Viçosa.

SANTOS, C.A.F.; REIS, H.S.; SEDIYAMA, C.S.; CRUZ, C.D.; SEDIYAMA, T. Parâmetros genéticos e seleção indireta em progênies F6 de um cruzamento de soja (Glycine max (L.) Merrill). Revista Ceres, v.42, n.240, p.155-166, 1995.

SCOTT, R.A.; MILLIKEN, G.A. A SAS program for analyzing augment randomized completed-blocks designs. Crop Science, v.33, p.865-867, 1993. 
SHANMUGASUNDARAM, S.; TSOU, S. C. S. Photoperiod and critical duration for flower induction in soybeans. Crop Science, v.18, p.598-601, 1978.

SHIMOYA, A. Comportamento de genótipos de soja (Glycine max (L.) Merrill) nas gerações $F_{9}$ e $F_{10}$ selecionados pelo método do teste de geração precoce. Viçosa, 1990, 132p. Dissertação (M.S.) - Universidade Federal de Viçosa.

SILVA, E. A. Análise de covariância em delineamentos de blocos aumentados (blocos de Federer). Piracicaba, 1987, 106 p. Dissertação (Mestrado) - Escola Superior de Agricultura "Luiz de Queiroz", Universidade de São Paulo.

SILVA, R. G.da. Métodos de genética quantitativa aplicados ao mellhoramento animal. Ribeirão Preto:SBG. 1982. 162p.

SINGH, T. P.; SINGH, K. B.; BRAR, J. S. Diallel analysis in soybean. Indian Journal of Genetic; Plant Breeding, v.34, n.3, p.427-432, Nov. 1974.

SISSON, V.A.; MILLER, P.A.; CAMPBELL, W.V.; VAN DUYN, J.W. Evidence of inheritance of resistance to the mexican bean beetle in soybeans. Crop Science, v.16, n.6, p.835-837, 1976.

SMITH, C.M. Expression, mechanisms and chemistry of resistance in soybean to the soybean looper, Pseudoplusia includens (WALKER). Insect Science and its Application, v.6, n.3, p.243-248, 1985. 
SMITH, C.M.; BRIM, C.A. Field and laboratory evaluations of soybean lines for resistance to corn earworm leaf feeding. Journal of Economic Entomology. v.72, n.1, p.78-80, 1979.

SMITH, C.M.; GILMAN, D.F. Comparative resistance of multiple insect resistance soybean genotypes to the soybean looper. Journal Economic Entomology, v.74, n.4, p.400-403, 1981.

SMITH, T.J.; CAMPER JUNIOR, H.M.; SCHILLINGER, J.A. Registration of Shore soybean. Crop Science, v.15, n.1, p.100, 1975.

SOSA-GÓMES, D.; MOSCARDI, F. Retenção foliar diferencial em soja provocada por percevejos (Heteroptera: Pentatomidae). Anais da Sociedade Entomológica do Brasil, v.24, n.2, p.401404, 1995

SOUZA, R.F. Análise genética da soja (Glycine max (L.) Merrill) sob infestações de percevejos. Londrina, 1992. p.81, Dissertação (Mestrado)- Universidade Estadual de Londrina.

SOUZA, R.F.\& TOLEDO, J.F.F. Genetic analysis of soybean resistance to stink bug. Revista Brasileira de Genetica, v.18, n.4, p.593-598, 1995.

SPEHAR, C. R. Breeding soybeans to the low latitudes of Brazilian cerrados (Savannahs). Pesquisa Agropecuária Brasileira, v.29, n.8, p.1167-1180, Ago. 1994. 
SPRAGUE, G.F. Quantitative genetics in plant improvement. In: FREY, K.J., (Ed.) Plant Breeding. Ames: lowa State University Press, 1966. p.315-354.

SPRAGUE, G.F.; TATUM, L.A. General vs. specific combining ability in single crosses of corn. Journal American Society Agronomy, v.34, n.10, p.923-932, 1942.

St. MARTIN, S. K. Effective population size for the soybean improvement program im maturity groups 00 to IV. Crop Science, v.22, n.1, p.151-152, Jan./Feb. 1982.

St. MARTIN, S. K. Epistasis and soybean breeding. Soybean Genetics Newsletter, v.8, p.104-107, Apr. 1981.

St. MARTIN, S. K.. The aplication of quantitative genetics theory to plant breeding problems. In: WORLD SOYBEAN RESEARCH CONFERENCE, 3., Ames, 1984, Proceeding. Boulder: Westview Press, 1985. p.311-317.

STEEL, R.G.D.; TORRIE, J.H. Principles and procedures in statistics. 2.ed. New York, McGraw-Hill, 1980. 633p.

SULLIVAN, M.J. Resistance to insect defoliators. In: WORLD SOYBEAN RESEARCH CONFERENCE, 3., Ames, 1985. Proceedings. Boulder: Westview Press, 1985. p.400-405.

SUMARNO; FEHR, W.R. response to recurrent selection for yield in soybeans. Crop Science, v.22, n.2, p.295-299, Mar/Apr 1982. 
TALEKAR, N.S.; LEE, H.R.; SUHARSONO. Resistance of soybean to four defoliator species in Taiwan. Journal of Economic Entomology, v.81, n.5, p.1469-1473, 1988.

TINGEY, W.M. The environmental control of insects using plant resistance. In: PIMENTEL, D. Handbook of pest management in agriculture. Boca Raton: CRC Press, 1981. p.195-197. (CRC Series in Agriculture).

TISSELLI FILHO, 0 . Inheritance study of the long-juvenile caracteristics in soybean under long and short day conditions. Mississipi, 1981. 77p. Thesis (PhD) - Mississipi State University).

TOLEDO, J.F.F. de; ALMEIDA, L.A de ; KIHLL, R.A.S.; MENOSSO, O, G. Ganho genético em soja no Estado do Paraná, via melhoramento. Pesquisa Agropecuária Brasileira, v.25, n.1, p.89-94, Jan. 1990.

TOLEDO, J.F.F.; KIIHL, R.A.S. Análise do modelo genético envolvido no controle de dias para o florescimento em soja. Pesquisa Agropecuária Brasileira, v.17, n.4, p.623-631, $1982 a$.

TOLEDO, J.F.F.; KIIHL, R.A.S. Métodos de análise dialélica do modelo genético em controle das características dias para a floração e número de folhas trifoliadas em soja. Pesquisa Agropecuária Brasileira, v.17, n.5, p.745-755, 1982b. 
TOMKINS, J.P.; SHIPE, E.R. Environmental adaptation of longjuvenile soybean cultivars and elite strains. Agronomy Journal, v.89, p.257-262, 1997.

TREVISOLI, S.H.U.; VELLO, N.A.; NEKATSCHALOW, M.C. cruzamentos óctuplos para ampliação da base genética em soja. In: CONGRESSO NACIONAL DE GENÉTICA, 43, Goiânia, 1997. Resumos. Goiânia:SBG, 1997. p.161.

TUART, L.D.; ROSE, I.A. Resistance to Heliothis armigera and Heliothis punctigera in three soybeans lines. Soybeans Genetics Newsletter, v.6, p.12-14, 1979.

TURNIPSEED, S.G.; KOGAN, M. Soybean Entomology. Annual Review of Entomology, v.21, p.247-281, 1976.

TURNIPSEED, S.G.; SULLIVAN, M.J. Plant resistance in soybean insect management. In: WORLD SOYBEAN RESEARCH CONFERENCE, 1., Proceedings. Danville: The Interstate Printes and Publishers, 1976. p.549-560.

VALÉRIO FILHO, W.V. Comparação de métodos para estimação de componentes de variância através de simulação de dados. Piracicaba, 1991. 160p. Tese (Doutorado) - Escola Superior de Agricultura "Luiz de Queiroz", Universidade de São Paulo.

VANDUYN, J.W.; TURNIPSEED, S.G.; MAXWEEL, J.D. Resistance in soybeans to mexican bean beetle. I. Sources of resistance. Crop Science, Madison, v.11, n.4, p.572-573, 1971. 
VANDUYN, J.W.; TURNIPSEED, S.G.; MAXWEEL, J.D. Resistance in soybeans to the mexican bean beetle II. Reactions of the beetle to resistant plants. Crop Science. v.12, n.5, p.561-562, 1972.

VELLO, N. A. Efeito da introdução de germoplasma exótico sobre a produtividade e relações com base genética dos cultivares de soja (Glycine max (L.) Merrill). Piracicaba, 1985. 91p. Tese (Livre-Docência) - Escola Superior de Agricultura "Luiz de Queiroz", Universidade de São Paulo.

VELLO, N.A. Ampliação da base genética do germoplasma e melhoramento da soja na ESALQIUSP. IN: SIMPÓSIO SOBRE A CULTURA E PRODUTIVIDADE DA SOJA, 1., Piracicaba, 1991. Anais. Piracicaba: FEALQ, 1992b. p.60-81.

VELLO, N.A. Métodos de melhoramento da soja. In: SIMPÓSIO SOBRE A CULTURA E PRODUTIVIDADE DA SOJA, 1., Piracicaba, 1991. Anais. Piracicaba: FEALQ, 1992a. p.41-59.

VENCOVSKY, R.; BARRIGA, P. Genética biométrica no fitomelhoramento. Ribeirão Preto: SBG, 1992. 486p.

VILLAS-BÔAS, G.L.; MOSCARDI, F.; FERREIRA, B.S.C.; CAMPO, C.B.H.; CORSO, I.C.; PANIZZI, A.R. Indicações do manejo de pragas para percevejos. Londrina: EMBRAPA- CNPSo,1985, p.15. 
VIZONI, E. Análise de experimentos em blocos casualizados completos aumentados (Blocos de Federer) com parcelas subdivididas no tempo. Piracicaba, 1984. 125p. Dissertação (Mestrado) - Escola Superior de Agricultura "Luiz de Queiroz", Universidade de São Paulo.

WEISS, M.G.; WEBER, C.R.; KALTON, R.R. Early generation testing in soybeans. Journal of the American Society of Agronomy, v.39, n.9., p.791-811, Sep. 1947.

WERNER, B. K.; WILCOX, J. R. Recurrent selection for yield in Glycine max using genetic male-sterility. Euphytica, v.50, n.1, p.19-26, 1990.

WRIGHT, S. Correlation and causation. Journal Agricultural Research, v.20, n.7, p.557-585, Jan. 1921. 
TABELAS 
Tabela 1. Esquema de análise de variância em blocos aumentados utilizando o resíduo intra-blocos.

\begin{tabular}{lccc} 
Fontes de Variação & $\mathrm{GL}$ & $\mathrm{QM}$ & $\mathrm{F}$ \\
\hline $\begin{array}{l}\text { Blocos ajustados } \\
\text { Tratamentos ajustados }\end{array}$ & $\mathrm{B}-1$ & - & - \\
Testemunhas & $\mathrm{T} \mathrm{P}_{\mathrm{i}}+\mathrm{T}-1$ & $\mathrm{QM}_{7}$ & $\mathrm{QM}_{7} / \mathrm{QM}_{1}$ \\
Test. Vs Progênies & 1 & $\mathrm{QM}_{6}$ & $\mathrm{QM}_{6} / \mathrm{QM}_{1}$ \\
Progênies & $\Sigma \mathrm{P}_{\mathrm{i}}-1$ & $\mathrm{QM}_{5}$ & $\mathrm{QM}_{5} / \mathrm{QM}_{1}$ \\
Cruzamentos & $\mathrm{C}-1$ & $\mathrm{QM}_{4}$ & $\mathrm{QM}_{4} / \mathrm{QM}_{1}$ \\
Prog. / Cruz. & $\Sigma \mathrm{P}_{\mathrm{i}}-\mathrm{C}$ & $\mathrm{QM}_{3}$ & $\mathrm{QM}_{3} / \mathrm{QM}_{1}$ \\
Resíduo intra & $(\mathrm{T}-1)(\mathrm{B}-1)$ & $\mathrm{QM}_{2}$ & $\mathrm{QM}_{2} / \mathrm{QM}_{1}$ \\
\end{tabular}

Total $\mathrm{N}-1$
onde,
$\mathrm{T}$ : número de testemunhas (tratamentos comuns);
$\mathrm{P}_{\mathrm{i}}$ : número de progênies do cruzamento i (tratamentos regulares);
$\quad \mathrm{i}=1,2, \ldots, \mathrm{C}$
$\mathrm{C}$ : número de cruzamentos;
$\mathrm{N}$ : número total de parcelas.


巨ิ

\&

i

ర్ల

$\triangle$

\&

잉

ฮิ ত̄

음

을

ᄋ

흥

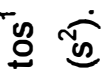

ํㅗํ

$\stackrel{0}{\circ}$

응

응 
હิ

용

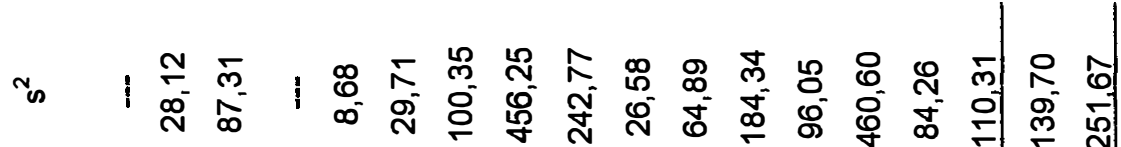

ํํำ

芒

घे

।

c - nEF n

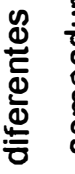

๕

$\frac{\pi}{\frac{0}{6}}$

कृ

응

$\frac{\pi}{0}$

क

宽

음

\&

हิ

홍

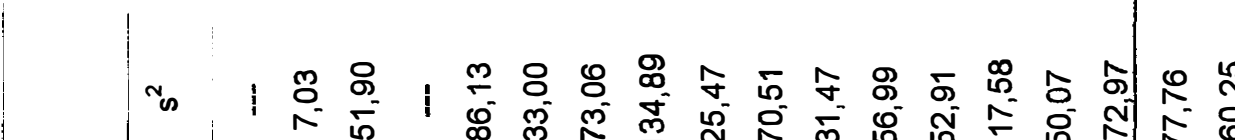

j

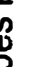

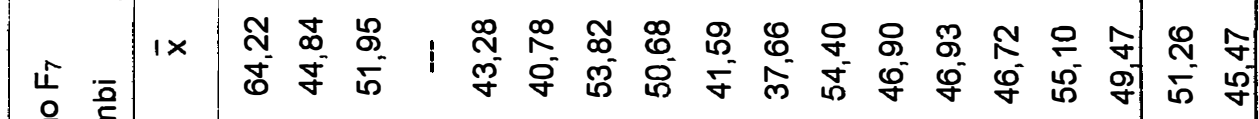

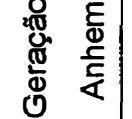

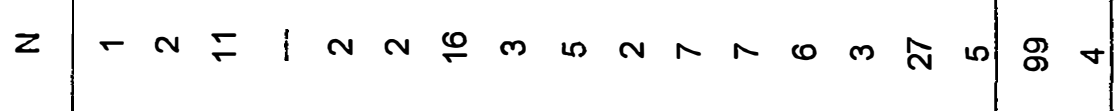

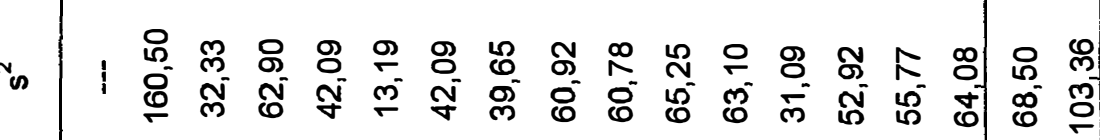

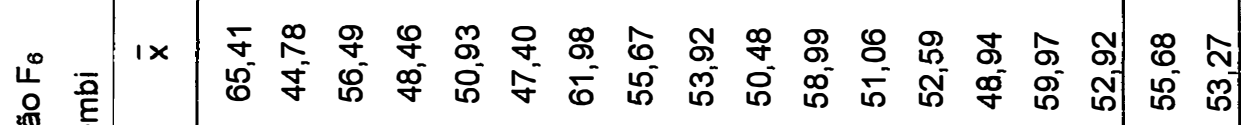

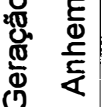

c - $-\frac{N}{2}$ a

ᄀ

N

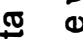

言

중

营

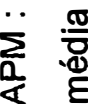

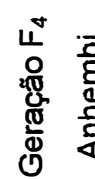

ํํㄹำ

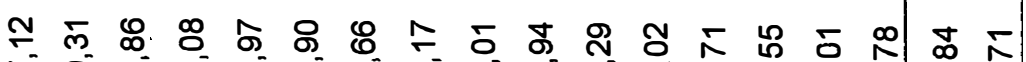
응 


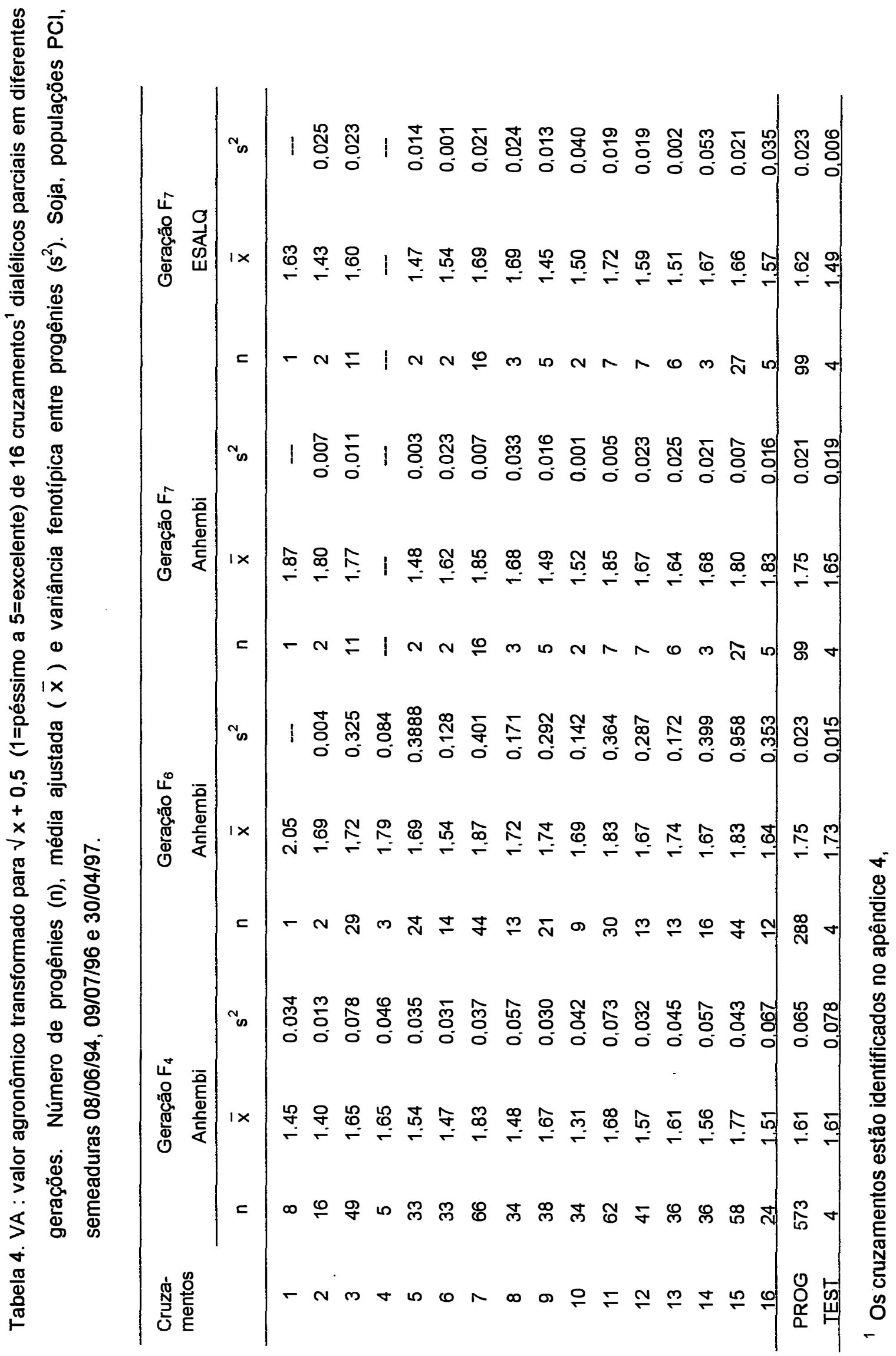


ลิ

:

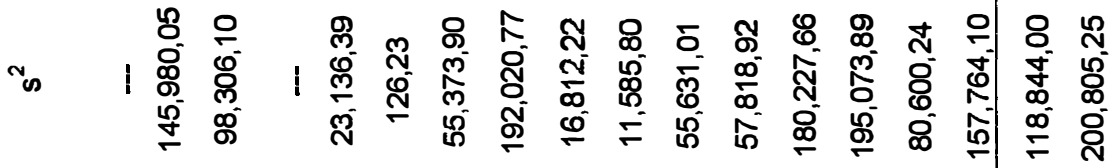

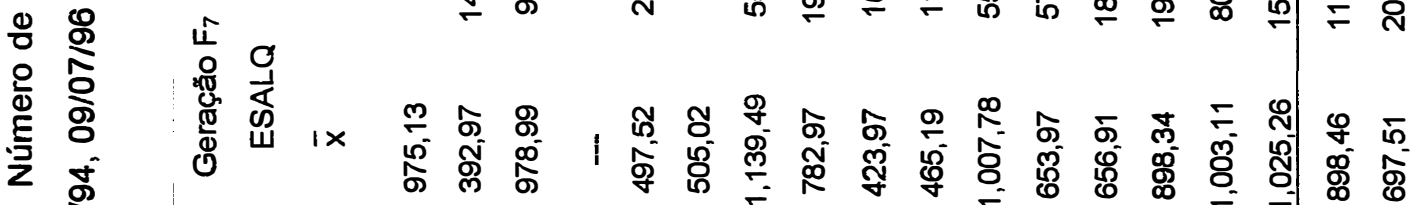

ฆ్ ญे

ฮั

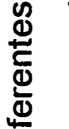

등

은

닌

:

¿̊.

๑

음

1

?

б

잉

으

$\because$ 뜽

()

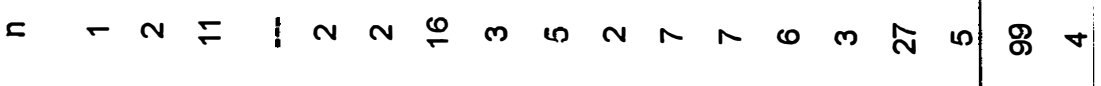

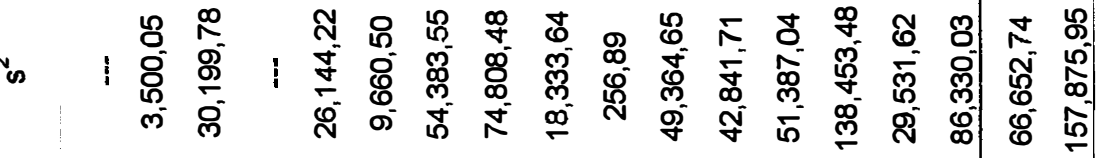

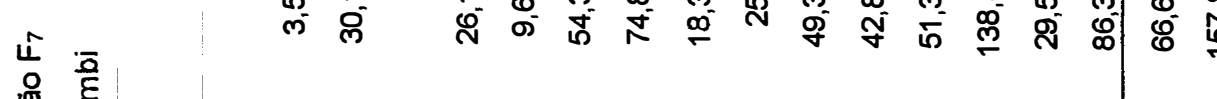

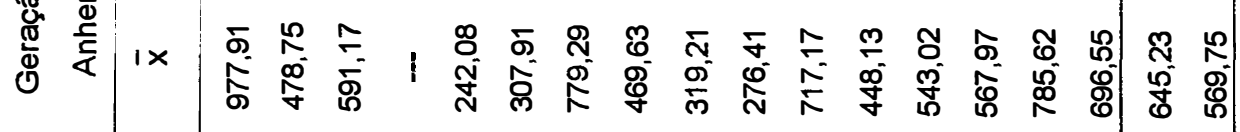

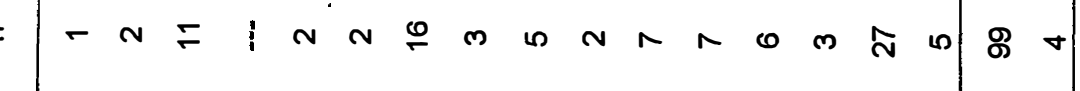

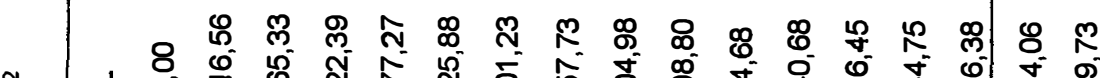

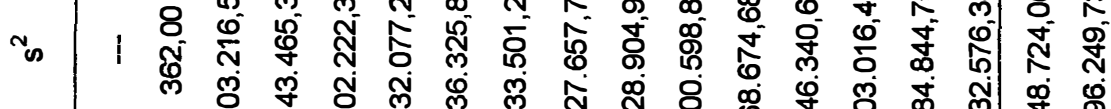

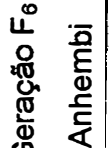
రิ

$\infty$

器

突 ํํㄴ

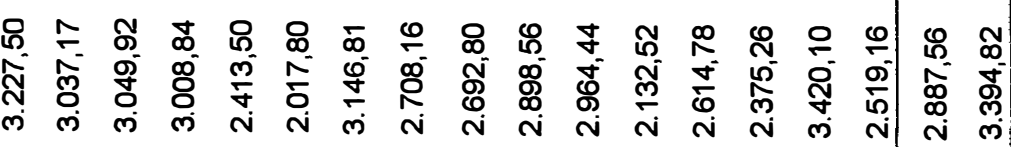

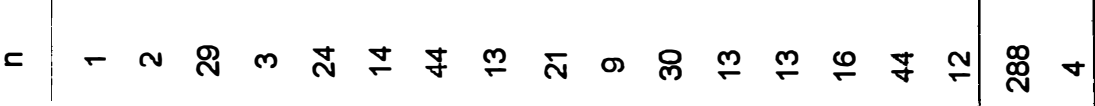

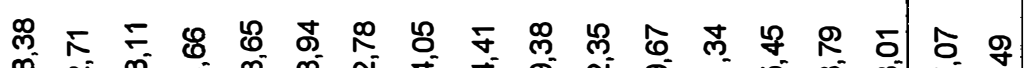

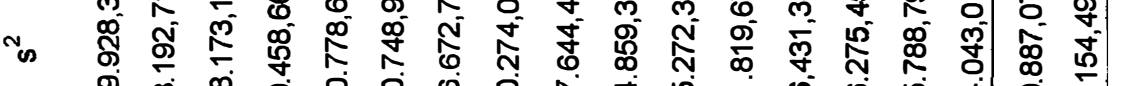

尔

范

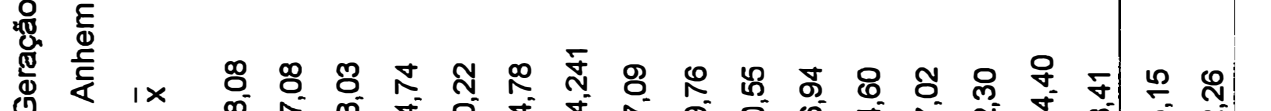

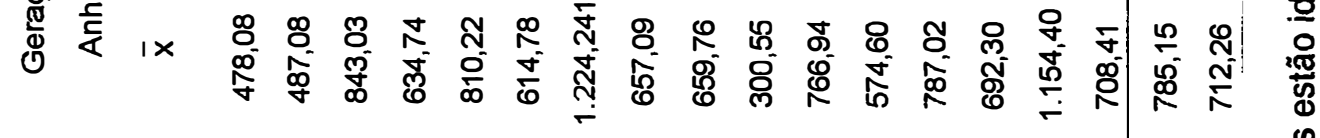

$\frac{8}{8}$

읃

ᄃ

$\stackrel{\substack{0 \\ \frac{C}{0}}}{E}$

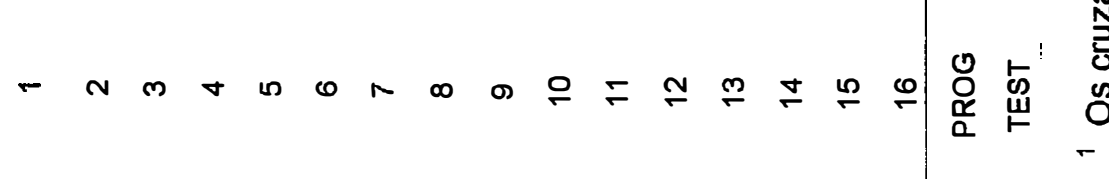




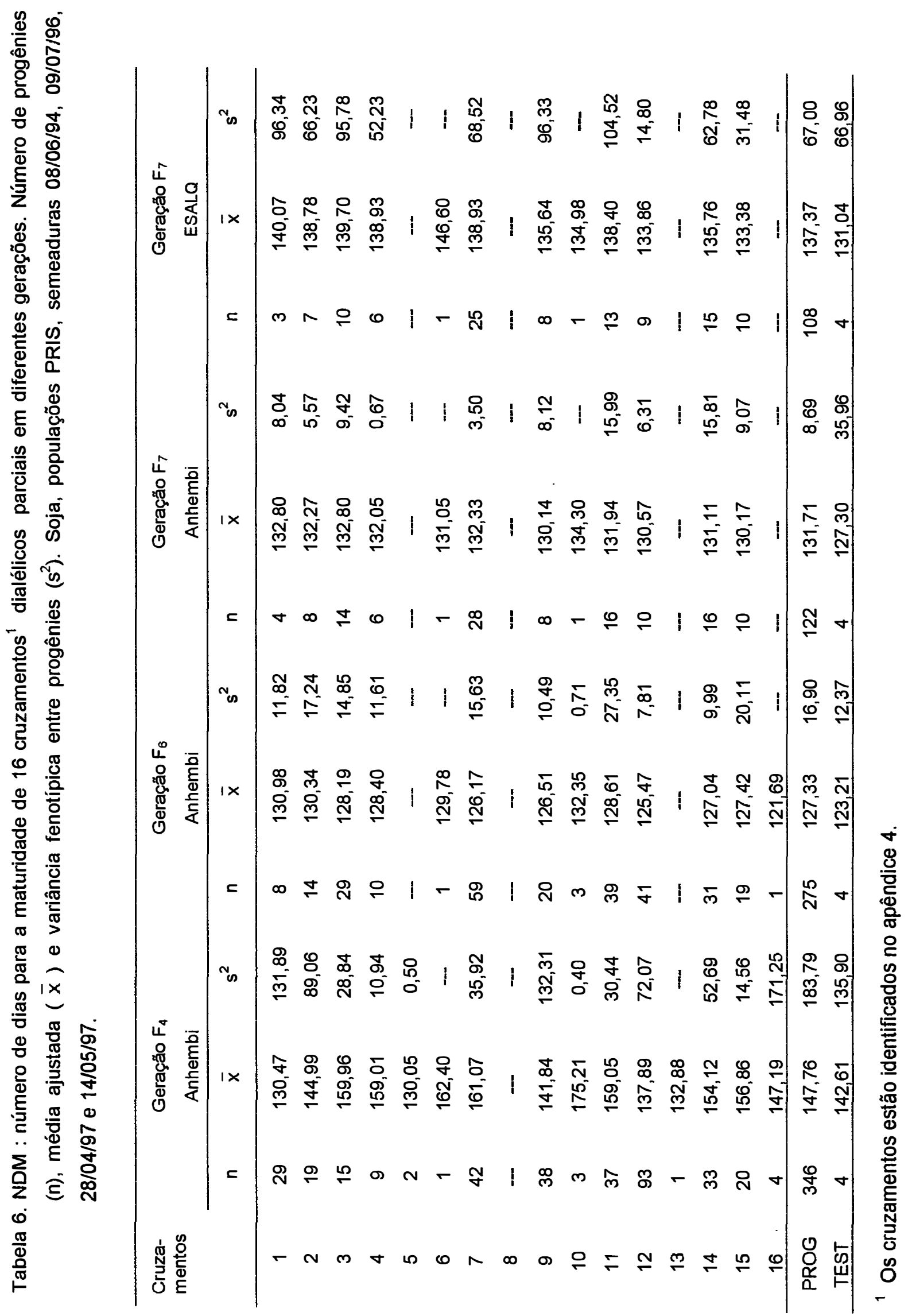




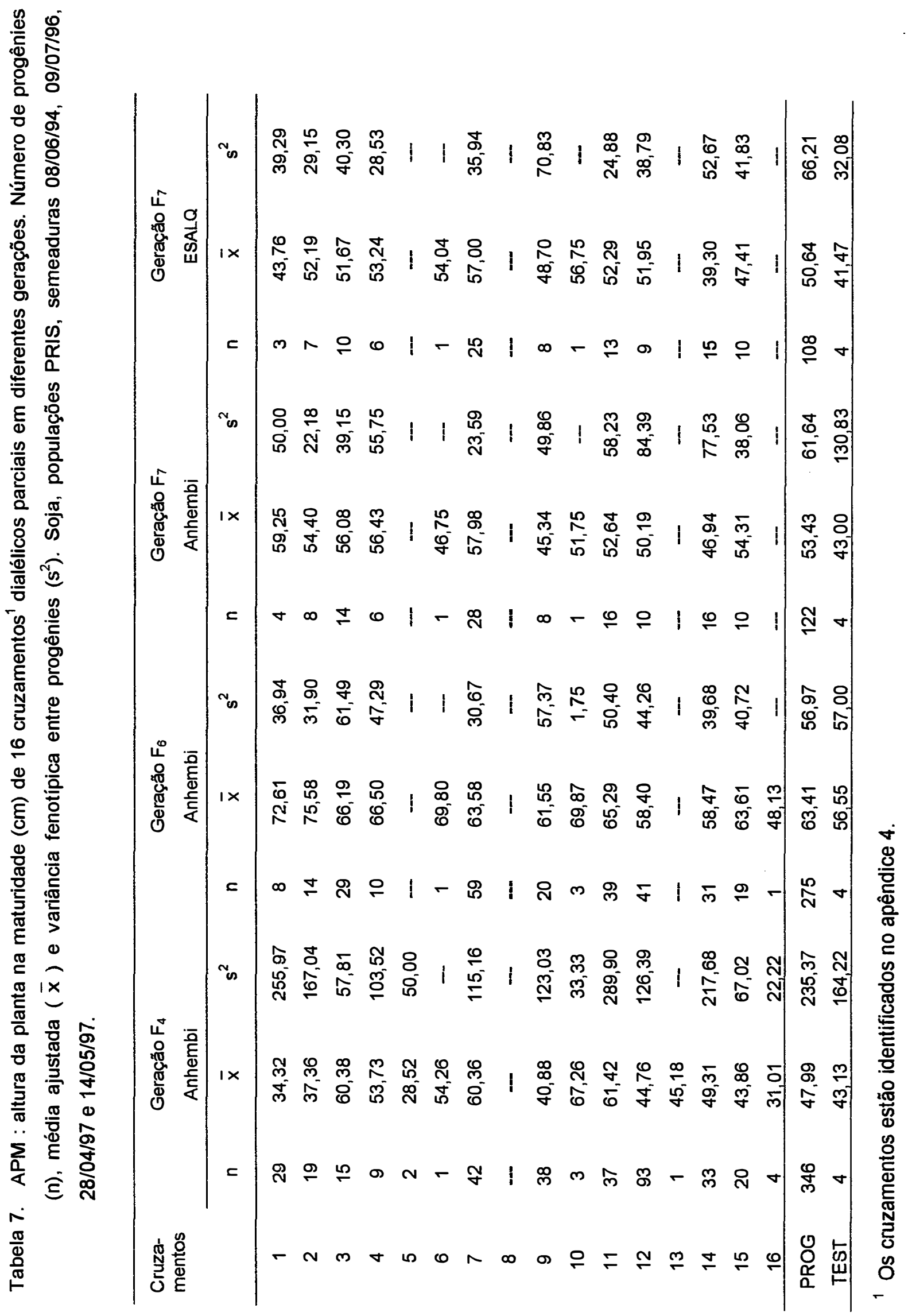




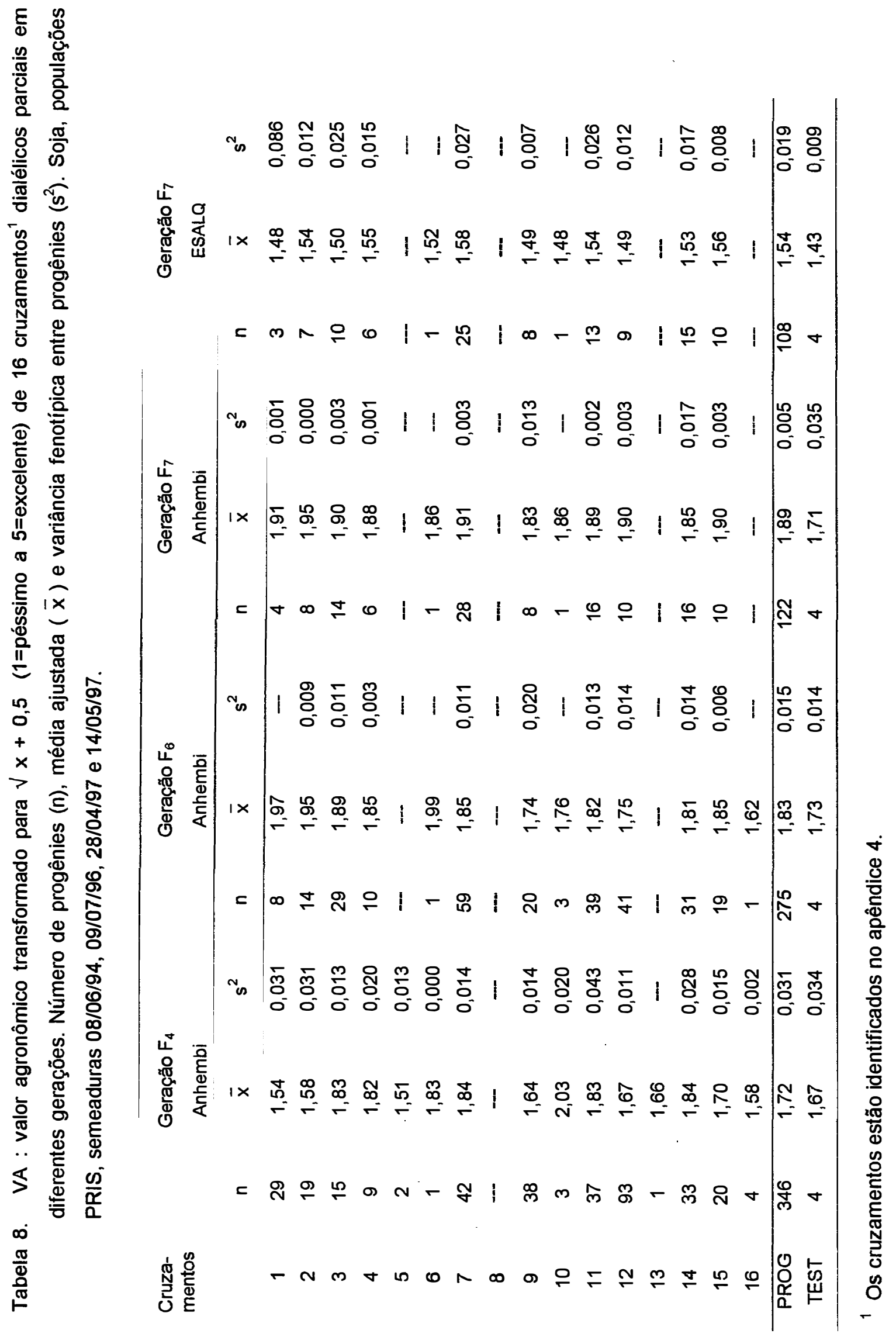




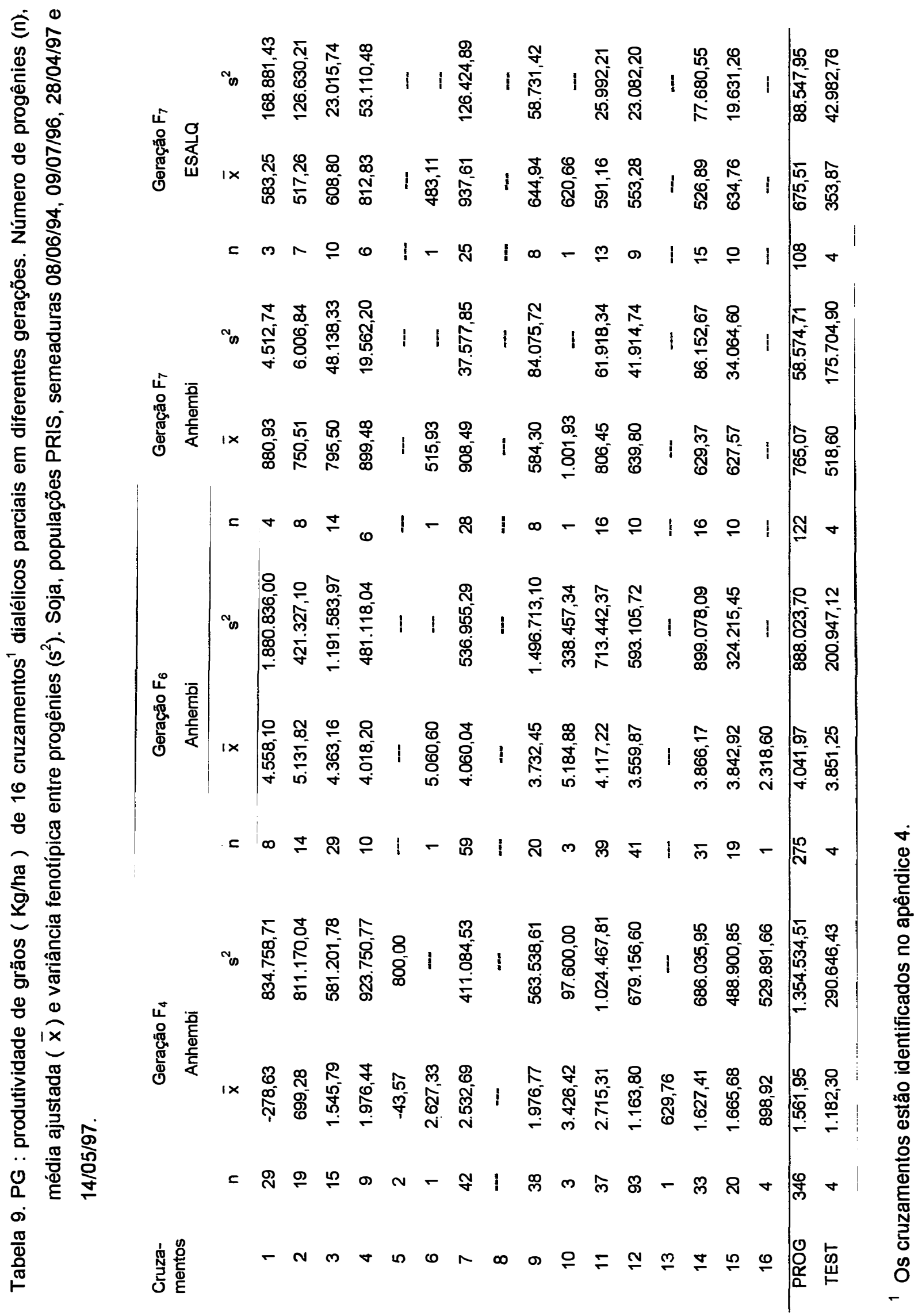




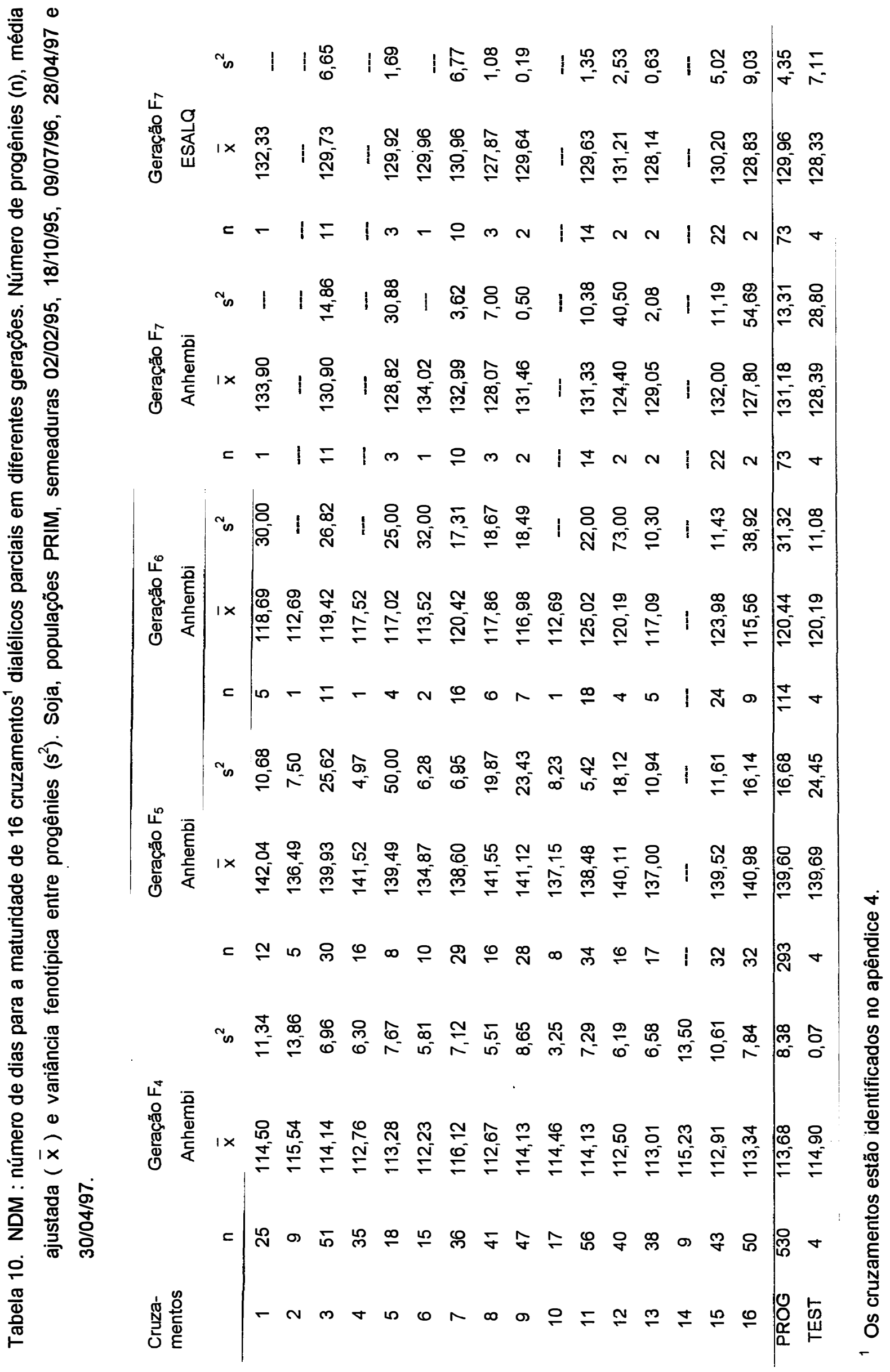




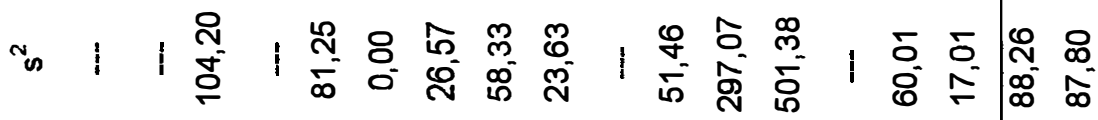

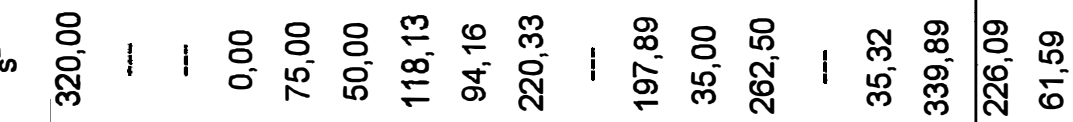

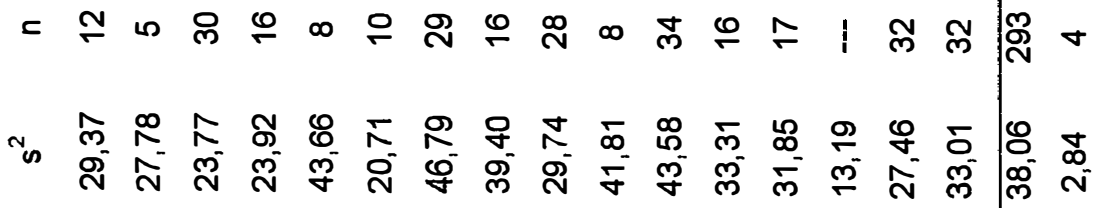
ลั - 


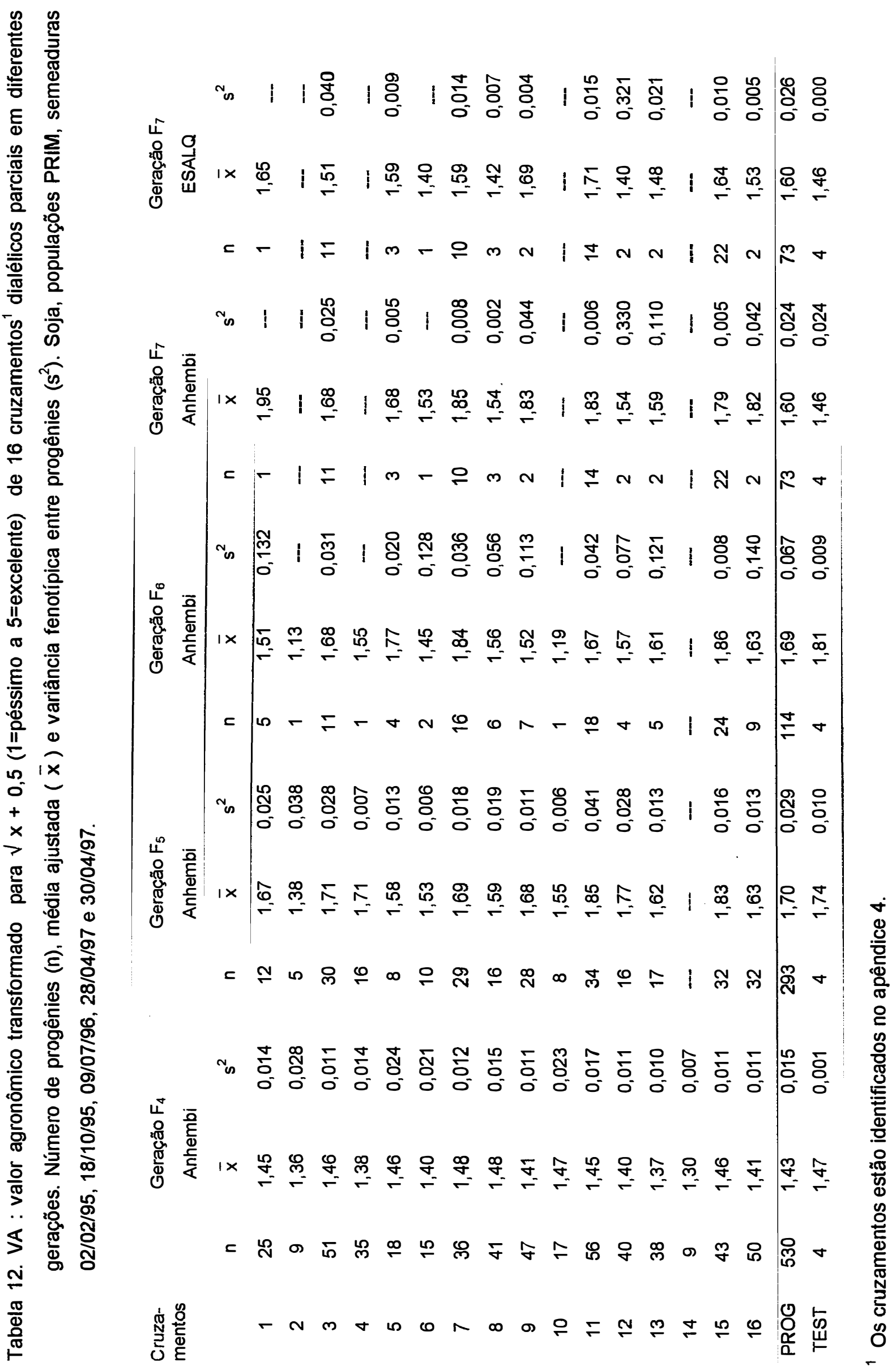




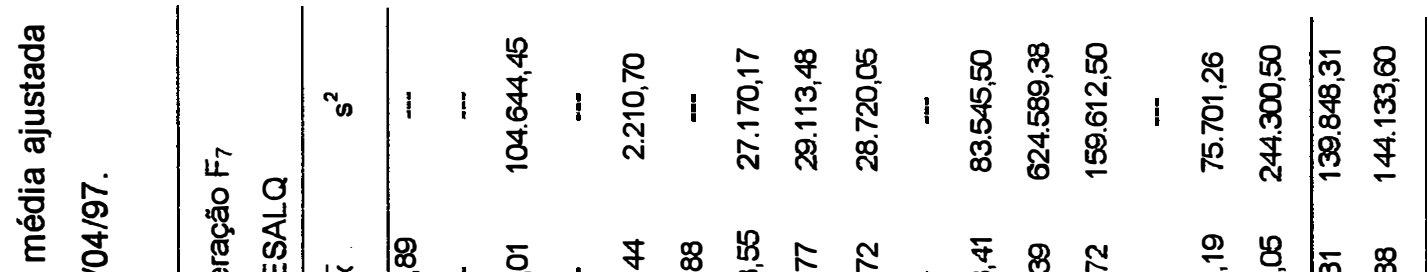

巨ิ

离

흥

\%

宽

@.

$\Phi$

क

ฮั

छ

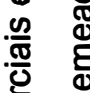

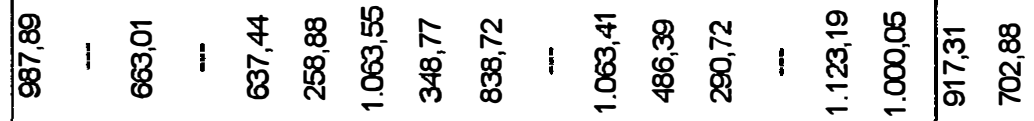

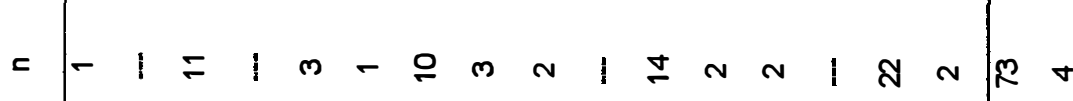

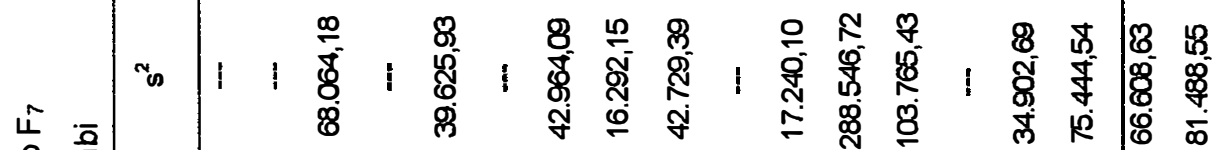

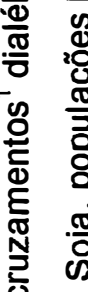

$\stackrel{0}{\mathscr{N}}$

\&

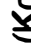

造

뜽 잉

吾

ن)

$\stackrel{m}{\circ}$

产

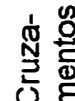

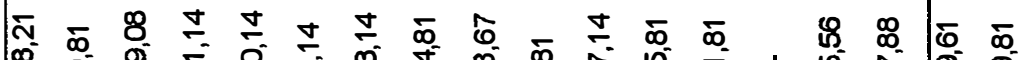
㠃

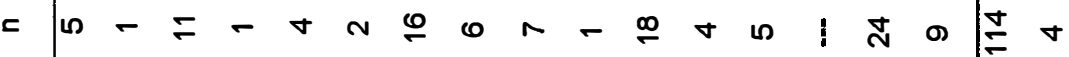

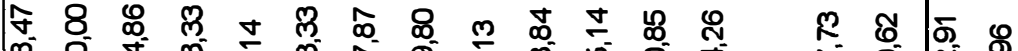
๘ ภํ.

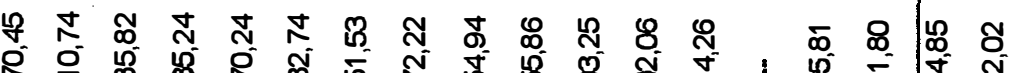

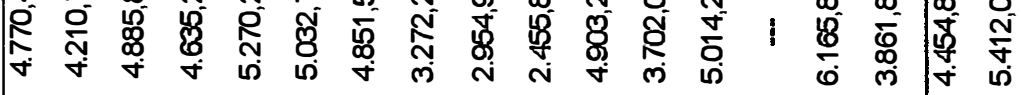
ᄃ ㄷ 8 \& 8 \% 8 \%

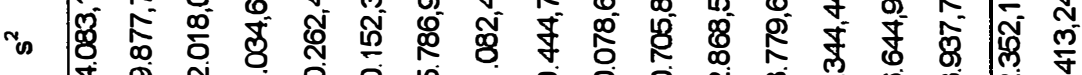

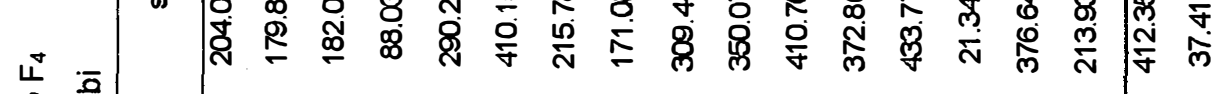

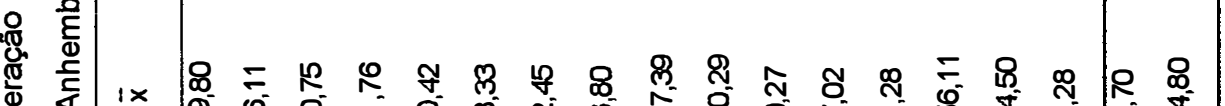

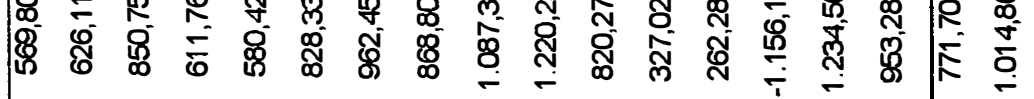

$\frac{\pi}{0}$ 
Tabela 14. Resumo da análise de variância com os valores e significância dos quadrados médios de quatro caracteres ${ }^{1}$.Soja, populações $\mathrm{PCl}$, geração $\mathrm{F}_{4}$, Anhembi - SP, semeadura em 08/06/94.

\begin{tabular}{lccccc}
\hline Fontes de Variação & GL & QM(NDM) & QM(APM) & QM(VA) & QM(PG) \\
\hline Blocos ajustados & 24 & $25,30^{\star \star}$ & $74,25^{\star \star}$ & $0,023^{\text {n,s, }}$ & $156.012,30^{\text {n.s. }}$ \\
Tratamentos ajustados & 576 & $175,36^{\star \star}$ & $198,05^{\star \star}$ & $0,070^{\star \star}$ & $312.406,06^{\star \star}$ \\
$\quad$ Testemunhas & 3 & $4.310,92^{\star \star}$ & $3.618,33^{\star \star}$ & $1,834^{\star \star}$ & $2.107 .204,95^{\star \star}$ \\
$\quad$ Test. Vs. Progênies & 1 & $101,29^{\star \star}$ & $6,74^{\text {n,s, }}$ & $0,001^{\text {n,s. }}$ & $326.772,50^{\text {n.s. }}$ \\
$\quad$ Progênies & 572 & $153,79^{\star \star}$ & $180,42^{\star \star}$ & $0,061^{\star \star}$ & $302.967,66^{\star \star}$ \\
$\quad$ Cruzamentos & 15 & $2.634,52^{\star \star}$ & $2.144,78^{\star \star}$ & $0,723^{\star \star}$ & $2.737 .477,91^{\star \star}$ \\
$\quad$ Prog. / Cruzamentos & 557 & $86,99^{\star \star}$ & $127,52^{\star \star}$ & $0,043^{\star \star}$ & $237.406,35^{\star \star}$ \\
Resíduointra & 57 & 3,85 & 25,53 & 0,014 & $96.554,50$ \\
\hline Total & 657 & & & & \\
\hline Média Geral & & 144,76 & 40,56 & 1,61 & 782,94 \\
Média Geral Testemunhas & & 143,74 & 40,82 & 1,61 & 725,08 \\
Média Geral Progênies & & 144,91 & 40,52 & 1,61 & 791,53 \\
Coeficiente de Variação (\%) & & 1,36 & 12,46 & 7,30 & 39,69 \\
\hline
\end{tabular}

Tabela 15. Resumo da análise de variância com os valores e significância dos quadrados médios de quatro caracteres ${ }^{1}$.Soja, populações $\mathrm{PCl}$, geração $\mathrm{F}_{6}$, Anhembi - SP, semeadura em 09/07/96.

\begin{tabular}{lccccc}
\hline Fontes de Variação & GL & QM(NDM) & QM(APM) & QM(VA) & QM(PG) \\
\hline Blocos ajustados & 24 & $22,07^{\star \star}$ & $37,87^{\text {n.s }}$ & $0,026^{\star}$ & $724.173,28^{\star}$ \\
Tratamentos ajustados & 291 & $33,83^{\star \star}$ & $151,68^{\star \star}$ & $0,046^{\star \star}$ & $1.280 .782,70^{\star \star}$ \\
$\quad$ Testemunhas & 3 & $428,99^{\star \star}$ & $2.808,67^{\star \star}$ & $0,483^{\star \star}$ & $5.505 .958,18^{\star \star}$ \\
$\quad$ Test. Vs. Progênies & 1 & $101,12^{\star \star}$ & $181,75^{\text {n.s }}$ & $0,007^{\text {n.s }}$ & $24.270 .340,50^{\star \star}$ \\
$\quad$ Progênies & 287 & $29,47^{\star \star}$ & $123,80^{\star \star}$ & $0,041^{\star \star}$ & $1.156 .514,12^{\star \star}$ \\
$\quad$ Cruzamentos & 15 & $306,90^{\star \star}$ & $1.480,88^{\star \star}$ & $0,484^{\star \star}$ & $11.561 .174,44^{\star \star}$ \\
$\quad$ Prog. / Cruzamentos & 272 & $14,17^{\star \star}$ & $48,96^{\text {n.s }}$ & $0,017^{\text {n.s }}$ & $582.727,70^{\star}$ \\
Resíduo intra & 72 & 3,63 & 53,69 & 0,015 & $399.109,03$ \\
\hline Total & 617 & & & & \\
\hline Média Geral & & 124,20 & 55,52 & 1,75 & $3.017,89$ \\
Média Geral Testemunhas & & 123,28 & 54,29 & 1,74 & $3.468,92$ \\
Média Geral Progênies & 124.38 & 55,76 & 1,75 & $2.930,81$ \\
Coeficiente de Variacāo (\%) & & 1,53 & 13,20 & 6,93 & 20,93 \\
\hline
\end{tabular}

${ }^{\star} \mathrm{e}^{\star \star}$ : significativo a $5 \%$ e $1 \%$ pelo teste $\mathrm{F}$, respectivamente.

1 Os caracteres estão identificados no apêndice 4. 
Tabela 16. Resumo da análise de variância com os valores e significância dos quadrados médios de quatro caracteres ${ }^{1}$.Soja, populações $\mathrm{PCl}$, geração $\mathrm{F}_{7}$, Anhembi - SP, semeadura em 28/04/97.

\begin{tabular}{|c|c|c|c|c|c|}
\hline Fontes de Variaçāo & $G L$ & $Q M(N D M)$ & QM(APM) & QM(VA) & $Q M(P G)$ \\
\hline Blocos ajustados & 7 & $5,03^{n . s}$ & $46,32^{n . s}$ & $0,016^{n . s}$ & $25.781,81^{n . s}$ \\
\hline Tratamentos ajustados & 102 & $23,40^{\star \star \star}$ & $199,89^{\star \star}$ & $0,048^{\star \star}$ & $165.724,27^{\star \star}$ \\
\hline Testemunhas & 3 & $195,03^{\star \star}$ & $1.282,03^{\text {t๘ }}$ & $0,152^{\star \star}$ & $1.263 .007 .63^{\star \star *}$ \\
\hline Test. Vs. Progênies & 1 & $106,32^{\star \star}$ & $910,01^{\star \star}$ & $0,295^{\star \star}$ & $154.070,84^{\star \star}$ \\
\hline Progênies & 98 & $17,30^{\star \star}$ & $159,52^{\star \star}$ & $0,042^{\star \star}$ & $132.252,88^{\star \star}$ \\
\hline Cruzamentos & 14 & $79,76^{\star \star}$ & $128,04^{\star \star}$ & $0,225^{\star \star}$ & $676.078,11^{\star \star}$ \\
\hline Prog. / Cruzamentos & 84 & $6,89^{\star \star}$ & $64.76^{n . s}$ & $0,011^{\star \star}$ & $41.615,34^{\star \star}$ \\
\hline Residua-intra & 21 & 2,51 & 40,36 & 0.007 & $14.466,34$ \\
\hline Total & 228 & & & & \\
\hline Média Geral & & 128,66 & 50,41 & $\overline{1,74}$ & 634,11 \\
\hline Média Geral Testemunhas & & 126,97 & 45,47 & 1.65 & 569,75 \\
\hline Média Geral Proqênies & & 128.93 & 51.22 & 1.76 & 644.56 \\
\hline Coeficiente de-Variação (\%) & & $-1,23$ & 12,60 & 4,97 & 18,97 \\
\hline
\end{tabular}

Tabela 17. Resumo da análise de variância com os valores e significância dos quadrados médios de quatro caracteres ${ }^{1}$.Soja, populações $\mathrm{PCl}$, geração $F_{7}$, ESALQ - Piracicaba, semeadura em 30/04/97.

\begin{tabular}{|c|c|c|c|c|c|}
\hline \multirow[b]{2}{*}{ Fontes de Variação } & & & & & \multirow[b]{2}{*}{ PG) } \\
\hline & GL & QM(NDM) & QM(APM) & QM(VA) & \\
\hline Blocos ajustados & 7 & $3,25^{\star \star}$ & $259,02^{\star \star}$ & $0,029^{n . s}$ & $213.654,61^{\star \star}$ \\
\hline Tratamentos aiustados & 102 & $11.44^{\star \star}$ & 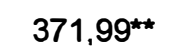 & $0,046^{\star *}$ & $321.580,43^{\star \star}$ \\
\hline Testemunhas & 3 & $38,33^{\star \star}$ & $2.109,95^{\star \star}$ & $0,058^{\star}$ & $1.692 .409,65^{\star \star}$ \\
\hline Test. Vs. Progênies & 1 & $39,27^{\star \star}$ & $3.505,61^{\star \star}$ & $0,426^{\star \star}$ & $1.128 .975,18^{\star \star}$ \\
\hline Progênies & 98 & $10,33^{\star \star}$ & $286,81^{\star \star}$ & $0,042^{\star \star}$ & $271.377 .55^{\star \star}$ \\
\hline Cruzamentos & 14 & $40,57^{\star \star}$ & $1.249,58^{\star \star}$ & $0,185^{\star \star}$ & $1.270 .347,04^{\star \star \star}$ \\
\hline Prog. / Cruzamentos & 84 & $5.29^{\star \star}$ & $126,35^{\star \star}$ & $0,018^{\text {n.s }}$ & $104.882,63^{\star \star}$ \\
\hline Residuo intra & 20 & 0,71 & 18,09 & 0.015 & $29.693,19$ \\
\hline Total & 226 & & & & \\
\hline Média Geral & & 128,30 & 57,07 & 1,60 & 869,46 \\
\hline Média Geral Testemunhas & & 127.26 & 44.19 & 1,49 & 692.13 \\
\hline Média Geral Progênies & & 128.47 & 55.64 & 1.62 & 897.50 \\
\hline Coeficiente de Variaçāo $(\%)$ & & 0,66 & 7.87 & 7,78 & 18,82 \\
\hline
\end{tabular}

${ }^{*} e^{\star \star}:$ significativo a $5 \%$ e $1 \%$ pelo teste $F$, respectivamente.

1 Os caracteres estão identificados no apêndice 4. 
Tabela 18. Resumo da análise de variância com os valores e significância dos quadrados médios de quatro caracteres ${ }^{1}$.Soja, populações PRIS, geração $F_{4}$, Anhembi - SP, semeadura em 08/06/94.

\begin{tabular}{|c|c|c|c|c|c|}
\hline Fontes de Variação & GL & QM(NDM) & QM(APM) & $Q M(V A)$ & $Q M(P G)$ \\
\hline Blocos ajustados & 13 & $61,31^{\star \star}$ & $115,34^{\text {n.s }}$ & $0,020^{\star}$ & $1.115 .546,41^{\star \star}$ \\
\hline Tratamentos ajustados & 349 & $341,70^{\star \star}$ & $538,45^{\star \star}$ & $0,083^{\star \star}$ & $2.191 .608,50^{\star \star}$ \\
\hline Testemunhas & 3 & $1.714,13^{\star \star}$ & $2.150,41^{\star \star}$ & $0,441^{\star \star}$ & $4.242 .383,88^{\star \star}$ \\
\hline Test. Vs. Progênies & 1 & $3.452 .86^{\star \star}$ & $2.688,30^{\star \star}$ & $0,451^{\star \star}$ & $14.520 .835,78^{\star \star \star}$ \\
\hline Progênies & 345 & $320,75^{\star \star}$ & $518,20^{\star \star}$ & $0.080^{\star \star}$ & $2.138 .038,78^{\star \star}$ \\
\hline Cruzamentos & 14 & $6.231,31^{\star \star}$ & $9.438,63^{\star \star}$ & $1,543^{\star \star}$ & $37.536 .034,36^{\star \star}$ \\
\hline Prog. / Cruzamentos & 331 & $70.76^{\star \star}$ & $140,90^{*}$ & $0.018^{\star \star *}$ & $640.842,59^{\star}$ \\
\hline Residuo intra & 28 & 16,71 & 74,66 & 0,008 & $369.396,96$ \\
\hline Total & 1052 & & & & \\
\hline Média Geral & & 152,37 & 52,12 & 1,78 & $1.795,78$ \\
\hline Média Geral Testemunhas & & 143,80 & 44,56 & 1,68 & $1.240,00$ \\
\hline Média Geral Progênies & & 152,75 & 52.46 & 1,79 & $1.820,60$ \\
\hline Coeficiente de Variacāo $(\%)$ & & 2,68 & 16,58 & 5,16 & 33,84 \\
\hline
\end{tabular}

Tabela 19. Resumo da análise de variância com os valores e significância dos quadrados médios de quatro caracteres ${ }^{1}$.Soja, populações PRIS, geração $F_{6}$, Anhembi - SP, semeadura em 09/07/96.

\begin{tabular}{lccccc}
\hline Fontes de Variação & GL & QM(NDM) & QM(APM) & QM(VA) & QM(PG) \\
\hline Blocos ajustados & 22 & $22,38^{\star \star}$ & $47,24^{\star \star}$ & $0,007^{\text {n.s }}$ & $572.607,26^{\star \star}$ \\
Tratamentos ajustados & 278 & $34,69^{\star \star}$ & $84,08^{\star \star}$ & $0,027^{\star \star}$ & $1.215 .649,41^{\star \star}$ \\
$\quad$ Testemunhas & 3 & $241,77^{\star \star}$ & $1.392,25^{\star \star}$ & $0,339^{\star \star}$ & $4.721 .852,96^{\star \star}$ \\
$\quad$ Test. Vs. Progênies & 1 & $707,71^{\star \star}$ & $2.386,46^{\star \star}$ & $0,583^{\star \star}$ & $3.549 .591,58^{\star \star}$ \\
$\quad$ Progênies & 274 & $29,96^{\star \star}$ & $61,36^{\star \star}$ & $0,021^{\star \star}$ & $1.168 .742,28^{\star \star}$ \\
$\quad$ Cruzamentos & 12 & $272,39^{\star \star}$ & $616,46^{\star \star}$ & $0,230^{\star \star}$ & $10.143 .141,18^{\star \star}$ \\
$\quad$ Prog. / Cruzamentos & 262 & $18,86^{\star \star}$ & $35,93^{\star \star}$ & $0,012^{\star \star}$ & $757.701,11^{\star \star}$ \\
Resíduo intra & 43 & 6,57 & 5,24 & 0,005 & $238.314,57$ \\
\hline Total & 520 & & & & \\
\hline Média Geral & & 127,08 & 62,22 & 1,83 & $4.097,58$ \\
Média Geral Testemunhas & & 124,10 & 56,74 & 1,74 & $3.886,32$ \\
Média Geral Progênies & & 127,54 & 63,05 & 1,84 & $4.129,83$ \\
Coeficiente de Variacão (\%) & & 2,02 & 3,68 & 3,82 & 11,91 \\
\hline
\end{tabular}

${ }^{*} e^{\star \star}$ : significativo a $5 \%$ e $1 \%$ pelo teste $F$, respectivamente.

1 Os caracteres estão identificados no apêndice 4. 
Tabela 20. Resumo da análise de variância com os valores e significância dos quadrados médios de quatro caracteres ${ }^{1}$.Soja, populações PRIS, geração $F_{7}$, Anhembi - SP, semeadura em 28/04/97.

\begin{tabular}{|c|c|c|c|c|c|}
\hline Fontes de Variação & $\mathrm{GL}$ & QM(NDM) & QM(APM) & QM(VA) & $Q M(P G)$ \\
\hline Blocos ajustados & 9 & $0,54^{n . s}$ & $41,94^{n . s}$ & $0,003^{n . s}$ & $16.865,36^{\text {n.s }}$ \\
\hline Tratamentos ajustados & 125 & $30,34^{\star \star}$ & $186,57^{\star \star}$ & $0,029^{\star \star}$ & $168.178,26^{\star \star}$ \\
\hline Testemunhas & 3 & $359,60^{\star \star}$ & $1.308,33^{\star \star}$ & $0,353^{\star \star}$ & $1.757 .049,07^{\star \star}$ \\
\hline Test. Vs. Progênies & 1 & $675,87^{\star \star}$ & $3.816 .70^{\star \star}$ & $1,124^{\star \star}$ & $2.112 .129,77^{\star \star}$ \\
\hline Progênies & 121 & $16,84^{\star \star}$ & $128,75^{\star \star}$ & $0,012^{\star \star}$ & $112.719,05^{\star \star}$ \\
\hline Cruzamentos & 11 & $101,19^{\star \star}$ & $957.53^{\star \star}$ & $0,073^{\star \star}$ & $763.795,08^{\star \star}$ \\
\hline Prog. / Cruzamentos & 110 & $8,41^{\star \star}$ & $45,88^{n . s}$ & $0,006^{n . s}$ & $47.611,45^{\star \star}$ \\
\hline Residua intra & 27 & 0,54 & 31,02 & 0.003 & 15.682 .28 \\
\hline Total & 280 & & & & \\
\hline Média Geral & & 131,11 & 52,05 & 1,87 & 731,41 \\
\hline Média Geral Testemunhas & & 127,30 & 43.00 & 1,72 & 518,60 \\
\hline Média Geral Progênies & & 131.74 & 53,55 & 1.90 & 766.73 \\
\hline Coeficiente de Variaçāo (\%) & & 0,56 & 10,70 & 3,14 & 17,12 \\
\hline
\end{tabular}

Tabela 21. Resumo da análise de variância com os valores e significância dos quadrados médios de quatro caracteres ${ }^{1}$.Soja, populações PRIS, geração $F_{7}$, ESALQ - Piracicaba, semeadura 14/05/97.

\begin{tabular}{|c|c|c|c|c|c|}
\hline Fontes de Variação & GL & QM(NDM) & QM(APM) & QM(VA) & $Q M(P G)$ \\
\hline Blocos ajustados & 9 & $21,37^{\star \star}$ & $52,74^{n . s}$ & $0,017^{n . s}$ & $49.465,54^{\star \star}$ \\
\hline Tratamentos aiustados & 111 & $140,03^{\star \star}$ & $115,36^{\star \star}$ & $0,038^{\star \star}$ & $197.697 .42^{\star \star}$ \\
\hline Testemunhas & 3 & $502,18^{\star \star \star}$ & $234,55^{\star \star}$ & $0,070^{\star \star}$ & $364.295,06^{\star \star}$ \\
\hline Test. Vs. Progênies & 1 & $1.563,05^{\star \star}$ & $2.991,94^{\star \star}$ & $0,518^{\star \star}$ & $3.674 .757,42^{\star \star}$ \\
\hline Progênies & 107 & $116,58^{\star \star}$ & $85,14^{\star \star}$ & $0,032^{\star \star}$ & $160.530,57^{\star \star}$ \\
\hline Cruzamentos & 11 & $550,75^{\star \star}$ & $561,82^{\star \star}$ & $0,161^{\star \star}$ & $995.916,12^{\star \star}$ \\
\hline Prog. / Cruzamentos & 96 & $66,83^{\star \star}$ & $30.52^{n . s}$ & $0,018^{\star \star}$ & $64.809,31^{\star \star}$ \\
\hline Resíduo intra & 21 & 1,20 & 35,24 & 0.010 & 1.719 .85 \\
\hline Total & 237 & & & & \\
\hline Média Geral & & 135,87 & 49,13 & 1,53 & 626,80 \\
\hline Média Geral Testemunhas & & 129.59 & 40,44 & 1,41 & 322,43 \\
\hline Média Geral Progênies & & 136.91 & 50,57 & 1.55 & 677.53 \\
\hline Coeficiente de Variacāo $(\%)$ & & 0,81 & 12,08 & 6,43 & 6.62 \\
\hline
\end{tabular}

${ }^{\star} \mathrm{e}^{\star \star}$ : significativo a $5 \%$ e $1 \%$ pelo teste $F$, respectivamente.

1 Os caracteres estão identificados no apêndice 4. 
Tabela 22. Resumo da análise de variância com os valores e significância dos quadrados médios de quatro caracteres ${ }^{1}$.Soja, populações PRIM, geração $F_{4}$, Anhembi - SP, semeadura 02/02/95.

\begin{tabular}{|c|c|c|c|c|c|}
\hline \multirow[b]{2}{*}{ Fontes de Variação } & & \multirow[b]{2}{*}{$Q M(A P M)$} & \multirow[b]{2}{*}{$Q M(V A)$} & \multirow[b]{2}{*}{$\mathrm{QM}(\mathrm{PG})$} \\
\hline & $\mathrm{GL}$ & QM(NDM) & & & \\
\hline Blocos ajustados & 31 & $1,92^{\text {n.s }}$ & $33,68^{n . s}$ & $0,009^{n . s}$ & $361.912,01^{n . s}$ \\
\hline Tratamentos aiustados & 533 & $9,17^{\star \star}$ & $36.99^{n . s}$ & $0,017^{\star}$ & $320.209 .72^{n . s}$ \\
\hline Testemunhas & 3 & $1,25^{n . s}$ & $94,71^{*}$ & $0,046^{\star \star}$ & $808.490,31^{n . s}$ \\
\hline Test. Vs. Progênies & 1 & $141,83^{\star \star}$ & $151,92^{\star}$ & $0.099^{\star \star}$ & $3.688 .643,79^{* *}$ \\
\hline Progênies & 529 & $8.96^{\star \star}$ & $36.45^{\mathrm{n} . \mathrm{s}}$ & $0,017^{\star}$ & $311.073 .09^{\text {n.s }}$ \\
\hline Cruzamentos & 15 & $61,79^{\star \star}$ & $302,66^{\star \star}$ & $0,088^{\star \star}$ & $2.775 .344,85^{\star \star}$ \\
\hline Prog. / Cruzamentos & 514 & $7,42^{\star \star \star}$ & $28,68^{n . s}$ & $0.015^{\text {n.s }}$ & $239.158 .55^{\mathrm{n} . \mathrm{s}}$ \\
\hline Resíduo intra & 72 & 1.26 & 28,87 & 0.011 & 323.698 .09 \\
\hline Total & 770 & & & & \\
\hline Média Geral & & 113,88 & 24,83 & 1,43 & 859,84 \\
\hline Média Geral Testemunhas & & 114.94 & 25.93 & 1,46 & 1.032 .15 \\
\hline Média Geral Proqênies & & 113,70 & 24.65 & 1.43 & 832.08 \\
\hline Coeficiente de Variação (\%) & & 0,98 & 21,64 & 7,39 & 63,17 \\
\hline
\end{tabular}

Tabela 23. Resumo da análise de variância com os valores e significância dos quadrados médios de quatro caracteres ${ }^{1}$.Soja, populações PRIM, geração $F_{5}$, Anhembi - SP, semeadura em 18/10/95.

\begin{tabular}{|c|c|c|c|c|c|}
\hline Fontes de Variação & GL & QM(NDM) & QM(APM) & QM(VA) & $Q M(P G)$ \\
\hline Blocos ajustados & 13 & $9,19^{\star \star}$ & $162,48^{n . s}$ & $0,008^{\text {n.s }}$ & $2.715 .921,38^{n . s}$ \\
\hline Tratamentos ajustados & 296 & $19,57^{\star \star}$ & $270,48^{\star}$ & $0,038^{\star \star}$ & $2.779 .922,88^{n . s}$ \\
\hline Testemunhas & 3 & $332,13^{\star \star}$ & $1.474,69^{\star \star}$ & $0,149 \star \star$ & $10.045 .466,53^{\star}$ \\
\hline Test. Vs. Progênies & 1 & $4,45^{n . s}$ & $1.1661,47^{\star \star}$ & $0,043^{\star}$ & $45.241 .717 .71^{\star \star}$ \\
\hline Progênies & 292 & $16,41^{\star \star}$ & $253,85^{\star}$ & $0,037^{\star \star}$ & $2.559 .859,78^{n . s}$ \\
\hline Cruzamentos & 14 & $87,66^{\star \star}$ & $2.731,18^{\star \star}$ & $0,349^{\star \star}$ & $19.560 .694,95^{\star \star}$ \\
\hline Prog. / Cruzamentos & 278 & $12,82^{\star \star}$ & $121,09^{n . s}$ & $0,021^{* *}$ & $1.703 .702,61^{n . s}$ \\
\hline Residuo intra & 36 & 2.70 & 161,54 & 0,006 & 2.464 .267 .60 \\
\hline Total & 395 & & & & \\
\hline Média Geral & & 139,80 & 64,13 & 1,71 & $4.602,02$ \\
\hline Média Geral Testemunhas & & 139,53 & 69,34 & 1,74 & $5.461,89$ \\
\hline Média Geral Progênies & & 139,84 & 63.32 & 1.71 & 4.469 .15 \\
\hline Coeficiente de Variacāo $(\%)$ & & 1,18 & 19,82 & 4,68 & 34,11 \\
\hline
\end{tabular}

${ }^{*} e^{\star *}$ : significativo a $5 \%$ e $1 \%$ pelo teste $F$, respectivamente.

1 Os caracteres estão identificados no apêndice 4. 
Tabela 24. Resumo da análise de variância com os valores e significância dos quadrados médios de quatro caracteres ${ }^{1}$.Soja, populações PRIM, geração $F_{6}$, Anhembi - SP, semeadura em 09/07/96.

\begin{tabular}{|c|c|c|c|c|c|}
\hline Fontes de Variação & $G L$ & QM(NDM) & QM(APM) & $Q M(V A)$ & $Q M(P G)$ \\
\hline Blocos ajustados & 6 & $7,42^{\star}$ & $57,92^{\mathrm{n.s}}$ & $0,018^{\text {n.s. }}$ & $299.898,67^{\star \star}$ \\
\hline Tratamentos aiustados & 117 & $32,09^{\star \star}$ & $212,78^{\star \star}$ & $0,070^{\text {n.s. }}$ & $1.250 .613 .99^{\star \star}$ \\
\hline Testemunhas & 3 & $55,50^{\star \star}$ & $347.79^{\star \star}$ & $0,059^{n . s .}$ & $422.905,60^{\star \star}$ \\
\hline Test. Vs. Progênies & 1 & $0,06^{\text {n.s }}$ & $576,69 \star \star$ & $0,218^{\text {n.s. }}$ & $10.594 .374,94^{\star \star}$ \\
\hline Progênies & 113 & $31,55^{\star \star}$ & $205,98^{\star}$ & $0.069^{\text {n.s. }}$ & $1.189 .900,40^{\star \star}$ \\
\hline Cruzamentos & 14 & $104,28^{\star \star}$ & $634,75^{\star \star}$ & $0,195^{\star \star}$ & $4.001 .565,04^{\star \star}$ \\
\hline Prog. / Cruzamentos & 99 & $21,49^{\text {t* }}$ & $145,34^{\star}$ & $0,051^{\text {n.s. }}$ & $792.291,26^{\star \star}$ \\
\hline Residuo intra. & 7 & 1,55 & 37,85 & 0.007 & 7.687 .31 \\
\hline Total & 130 & & & & \\
\hline Média Geral & & 120,30 & 57,21 & 1,73 & $2,591,57$ \\
\hline Média Geral Testemunhas & & 120.35 & 62.65 & 1,83 & $3.328,00$ \\
\hline Média Geral Progênies & & 120,39 & 56.40 & 1.71 & 2.481 .75 \\
\hline Coeficiente de Variaçäo (\%) & & 1,03 & 10,75 & 4,84 & 3,38 \\
\hline
\end{tabular}

Tabela 25. Resumo da análise de variância com os valores e significância dos quadrados médios de quatro caracteres ${ }^{1}$.Soja, populações PRIM, geração $F_{7}$, Anhembi - SP, semeadura em 28/04/97.

\begin{tabular}{lccccc}
\hline Fontes de Variação & GL & QM(NDM) & QM(APM) & QM(VA) & QM(PG) \\
\hline Blocos ajustados & 5 & $0,48^{\text {n.s }}$ & $46,50^{\star}$ & $0,019^{\text {n.s }}$ & $17.423,64^{\star}$ \\
Tratamentos ajustados & 76 & $32,30^{\star \star}$ & $186,75^{\star \star}$ & $0,056^{\star \star}$ & $149.132,47^{\star \star}$ \\
$\quad$ Testemunhas & 3 & $164,10^{\star \star}$ & $530,70^{\star \star}$ & $0,145^{\star \star}$ & $448.969,99^{\star \star}$ \\
$\quad$ Test. Vs. Progênies & 1 & $185,14^{\star \star}$ & $602,70^{\star \star}$ & $0,174^{\star \star}$ & $428.710,93^{\star \star}$ \\
$\quad$ Progênies & 72 & $24,69^{\star \star}$ & $166,64^{\star \star}$ & $0,050^{\star \star}$ & $132.756,20^{\star \star}$ \\
$\quad$ Cruzamentos & 11 & $95,96^{\star \star}$ & $706,13^{\star \star}$ & $0,216^{\star \star}$ & $623.735,14^{\star \star}$ \\
$\quad$ Prog. / Cruzamentos & 61 & $11,83^{\star \star}$ & $69,36^{\star \star}$ & $0,020^{\text {n.s }}$ & $44.219,02^{\star \star}$ \\
Residuo intra & 14 & 3,33 & 11,13 & 0,011 & $5.309,82$ \\
\hline Total & 165 & & & & 608,80 \\
\hline Média Geral & & 130,81 & 48,01 & 1,75 & 482,09 \\
Média Geral Testemunhas & & 128,17 & 43,26 & 1,67 & 629,18 \\
Média Geral Progênies & & 131,23 & 48,78 & 1.76 & 11,97 \\
Coeficiente de Variação (\%) & & 1,39 & 6,95 & 6.02 & \\
\hline
\end{tabular}

${ }^{\star} e^{\star \star}$ : significativo a $5 \%$ e $1 \%$ pelo teste $F$, respectivamente.

1 Os caracteres estão identificados no apêndice 4. 
Tabela 26. Resumo da análise de variância com os valores e significância dos quadrados médios de quatro caracteres $^{1}$.Soja, populações PRIM, geração $F_{7}$, ESALQ - Piracicaba, semeadura em 30/04/97.

\begin{tabular}{lccccc}
\hline Fontes de Variação & GL & QM(NDM) & QM(APM) & QM(VA) & QM(PG) \\
\hline Blocos ajustados & 5 & $1,27^{\text {n.s }}$ & $35,54^{\text {n.s }}$ & $0,001^{\text {n.s }}$ & $91.763,67^{\text {n.s }}$ \\
Tratamentos ajustados & 76 & $9,73^{\star \star}$ & $325,59^{\star \star}$ & $0,043^{\star \star}$ & $290.010,26^{\star \star}$ \\
$\quad$ Testemunhas & 3 & $42,67^{\star \star}$ & $1.312,15^{\star \star}$ & $0,001^{\text {n.s }}$ & $864.801,58^{\star \star}$ \\
Test. Vs. Progênies & 1 & $55,12^{\star \star}$ & $2.161,64^{\star \star}$ & $0,449^{\star \star}$ & $1.142 .020,56^{\star \star}$ \\
$\quad$ Progênies & 72 & $7,73^{\star \star}$ & $258,98^{\star \star}$ & $0,040^{\star \star}$ & $254.227,15^{\star \star}$ \\
$\quad$ Cruzamentos & 11 & $26,94^{\star \star}$ & $1.088,81^{\star \star \star}$ & $0,146^{\star \star}$ & $1.184 .252,55^{\star \star}$ \\
$\quad$ Prog. / Cruzamentos & 61 & $4,26^{\star \star}$ & $109,34^{\text {n.s }}$ & $0,021^{\star}$ & $86.517,65^{\text {n.s }}$ \\
Resíduo intra & 15 & 1,27 & 86,32 & 0,008 & $83.798,44$ \\
\hline Total & 165 & & & & \\
\hline Média Geral & & 129,73 & 54,82 & 1,59 & 904,64 \\
Média Geral Testemunhas & & 128,33 & 46,04 & 1,46 & 702,89 \\
Média Geral Progênies & & 129,97 & 56,30 & 1,61 & 938,74 \\
Coeficiente de Variação (\%) & & 0,87 & 16,95 & 5.83 & 32,00 \\
\hline
\end{tabular}

${ }^{*} e^{\star \star}$ : significativo a $5 \%$ e $1 \%$ pelo teste $F$, respectivamente.

1 Os caracteres estão identificados no apêndice 4. 
Tabela 27. Parâmetros da regressão linear para os caracteres NDM, APM, VA e PG nos diferentes tipos de populações: coeficiente linear da reta (a), coeficiente angular da reta (b), b em porcentagem de a (b\%), coeficiente de determinação $\left(R^{2}\right)$ e equação da reta de regressão (Eq.).

\begin{tabular}{|c|c|c|c|c|c|}
\hline \multirow[t]{2}{*}{ Populações } & \multicolumn{5}{|c|}{ NDM (dias) } \\
\hline & a & b & $\mathrm{b} \%$ & $r^{2}$ & Eq. \\
\hline $\mathrm{PCl}$ & $119,4195^{*}$ & 1,6909 & 1,4159 & 0,9645 & $Y=119,4195+1,6909 X$ \\
\hline PRIS & $126,2026^{*}$ & 1,2086 & 0,9577 & 0,9249 & $Y=126,2026+1,2086 X$ \\
\hline \multirow[t]{3}{*}{ PRIM } & $125,3753^{\star *}$ & 0,9225 & 0,7358 & 0,4040 & $Y=125,3753+0,9225 X$ \\
\hline & \multicolumn{5}{|c|}{ APM $(\mathrm{cm})$} \\
\hline & $a$ & b & $\mathrm{b} \%$ & $r^{2}$ & Eq. \\
\hline $\mathrm{PCl}$ & 36,2295 & 2,3293 & 6,4293 & 0,8856 & $Y=36,2295+2,3293 X$ \\
\hline PRIS & 38,7254 & 2,8026 & 7,2371 & 0,9497 & $Y=38,7254+2,8026 X$ \\
\hline \multirow[t]{3}{*}{ PRIM } & 21,1042 & 2,8352 & 9,1152 & 0,2338 & $Y=31,1042+2,8352 X$ \\
\hline & \multicolumn{5}{|c|}{ VA (nota) } \\
\hline & $a$ & $\mathrm{~b}$ & $\mathrm{~b} \%$ & $r^{2}$ & Eq. \\
\hline $\mathrm{PCl}$ & $1,3118^{*}$ & 0,0581 & 4,4290 & 0,9827 & $Y=1,3118+0,0581 X$ \\
\hline PRIS & $1,4713^{*}$ & 0,0468 & 3,1809 & 0,8827 & $Y=1,4713+0,0468 X$ \\
\hline \multirow[t]{3}{*}{ PRIM } & $1,4382^{*}$ & 0,0341 & 2,3710 & 0,1452 & $Y=1,4382+0,0341 X$ \\
\hline & \multicolumn{5}{|c|}{ PG (Kg/ha) } \\
\hline & $a$ & $\mathrm{~b}$ & $\mathrm{~b} \%$ & $r^{2}$ & Eq. \\
\hline $\mathrm{PCl}$ & $1,696,4555$ & $-17,8579$ & $-1,0527$ & 0,0061 & $Y=1.696,4555-17,8579 X$ \\
\hline PRIS & $1,880,3923$ & 19,1677 & 1,0193 & 0,0683 & $Y=1.880,3923+19,1677 X$ \\
\hline PRIM & 297,8966 & 165,0065 & 55,3905 & 0,0990 & $Y=297,8966+165,0065 X$ \\
\hline
\end{tabular}

${ }^{*} e^{\star \star}$ significativo a $5 \%$ e $1 \%$, respectivamente. 
Tabela 28. Número total de progênies $(n)$, média geral $(x)$ e variância geral $\left(s^{2}\right)$ para os caracteres NDM, APM, VA e PG, nos diferentes tipos de populações e nas sucessivas gerações de endogamia, após análise envolvendo todos ambientes.

Populações

\begin{tabular}{|c|c|c|c|c|c|}
\hline & NDM (dias) & $\overline{F_{4: 2}}$ & $F_{5: 2}$ & $F_{6: 2}$ & $F_{7: 2}$ \\
\hline $\mathrm{PCl}$ & $\begin{array}{l}n \\
x \\
s^{2}\end{array}$ & $\begin{array}{c}573 \\
126,0 \\
151,19 \\
\end{array}$ & --- & $\begin{array}{c}288 \\
130,1 \\
15,20 \\
\end{array}$ & $\begin{array}{c}99 \\
130,9 \\
5,72 \\
\end{array}$ \\
\hline PRIS & $\begin{array}{l}n \\
x \\
s^{2} \\
\end{array}$ & $\begin{array}{c}346 \\
131,2 \\
183,80\end{array}$ & -- & $\begin{array}{c}275 \\
132,9 \\
16,90\end{array}$ & $\begin{array}{c}122 \\
135,1 \\
24,65 \\
\end{array}$ \\
\hline PRIM & $\begin{array}{l}\mathrm{n} \\
\mathrm{x} \\
\mathrm{s}^{2}\end{array}$ & $\begin{array}{c}530 \\
128,4 \\
8,38\end{array}$ & $\begin{array}{c}293 \\
131,8 \\
16,68 \\
\end{array}$ & $\begin{array}{c}114 \\
129,4 \\
31,32\end{array}$ & $\begin{array}{c}73 \\
132,2 \\
6,52\end{array}$ \\
\hline
\end{tabular}

Populações

Gerações

\begin{tabular}{|c|c|c|c|c|c|}
\hline & APM $(\mathrm{cm})$ & $F_{4: 2}$ & $F_{5: 2}$ & $\mathrm{~F}_{6: 2}$ & $F_{7: 2}$ \\
\hline & $\mathbf{n}$ & 573 & -- & 288 & 99 \\
\hline $\mathrm{PCl}$ & $\begin{array}{l}x \\
s^{2}\end{array}$ & $\begin{array}{c}46,0 \\
183,49\end{array}$ & -- & $\begin{array}{c}48,8 \\
68,50\end{array}$ & $\begin{array}{c}53,5 \\
87,40\end{array}$ \\
\hline PRIS & $\begin{array}{l}n \\
x \\
s^{2}\end{array}$ & $\begin{array}{c}346 \\
50,3 \\
235,38 \\
\end{array}$ & -- & $\begin{array}{c}275 \\
54,4 \\
56,98 \\
\end{array}$ & $\begin{array}{c}122 \\
59,1 \\
47,92\end{array}$ \\
\hline PRIM & $\begin{array}{l}\mathrm{n} \\
\mathrm{x} \\
\mathrm{s}^{2}\end{array}$ & $\begin{array}{c}530 \\
48,0 \\
38,06\end{array}$ & $\begin{array}{c}293 \\
40,1 \\
261,70\end{array}$ & $\begin{array}{c}114 \\
41,8 \\
226,09\end{array}$ & $\begin{array}{c}73 \\
56,9 \\
81,76\end{array}$ \\
\hline
\end{tabular}

Populações

\begin{tabular}{|c|c|c|c|c|c|}
\hline \multirow{4}{*}{$\mathrm{PCl}$} & VA (nota) & $F_{4: 2}$ & $F_{5: 2}$ & $F_{6: 2}$ & $F_{7: 2}$ \\
\hline & $\mathrm{n}$ & 573 & --- & 288 & 99 \\
\hline & $x$ & 1,5 & --- & 1,6 & 1,7 \\
\hline & $s^{2}$ & 0,07 & - & 0,02 & 0,02 \\
\hline \multirow{3}{*}{ PRIS } & $\mathbf{n}$ & 346 & -- & 275 & 122 \\
\hline & $x$ & 1,7 & --- & 1,7 & 1,8 \\
\hline & $s^{2}$ & 0,03 & -- & 0,02 & 0,01 \\
\hline \multirow{3}{*}{ PRIM } & n & 530 & 293 & 114 & 73 \\
\hline & $x$ & 1,6 & 1,6 & 1,5 & 1,8 \\
\hline & $s^{2}$ & 0,02 & 0,03 & 0,07 & 0,02 \\
\hline
\end{tabular}

Populações

Gerações

\begin{tabular}{|c|c|c|c|c|c|}
\hline & PG (Kg/ha) & $F_{4: 2}$ & $F_{5: 2}$ & $F_{6: 2}$ & $F_{7: 2}$ \\
\hline $\mathrm{PCl}$ & $\begin{array}{l}n \\
x \\
s^{2}\end{array}$ & $\begin{array}{c}573 \\
1.756,20 \\
300.888,81\end{array}$ & $\begin{array}{l}-- \\
-- \\
-\end{array}$ & $\begin{array}{c}288 \\
1.195,90 \\
748.723,95 \\
\end{array}$ & $\begin{array}{c}99 \\
1.833,70 \\
79.041,38 \\
\end{array}$ \\
\hline PRIS & $\begin{array}{l}n \\
x \\
s^{2}\end{array}$ & $\begin{array}{c}346 \\
1.997,90 \\
1.354 .534,87\end{array}$ & $\cdots$ & $\begin{array}{c}275 \\
1.872,80 \\
888.023,81 \\
\end{array}$ & $\begin{array}{c}122 \\
2.096,30 \\
55.271,12\end{array}$ \\
\hline PRIM & $\begin{array}{l}n \\
x \\
s^{2}\end{array}$ & $\begin{array}{c}530 \\
1.548,40 \\
412.351,66\end{array}$ & $\begin{array}{c}293 \\
448,80 \\
2.742 .763,30\end{array}$ & $\begin{array}{c}114 \\
864,90 \\
1.164 .809,33\end{array}$ & $\begin{array}{c}73 \\
1.959,70 \\
88.440,60\end{array}$ \\
\hline
\end{tabular}


Tabela 29. Capacidade média de combinação $\left(\mathrm{cmc}_{\mathrm{i}}\right)$ dos parentais, nos três tipos de populações, para o número de dias para a maturidade (dias) com base no desempenho de suas linhagens dos 16 cruzamentos dialélicos parciais, em Anhembi e ESALQ. Soja, Piracicaba-SP.

Parentais

Populaçōes PCI

$\begin{array}{lcccc} & \mathrm{F}_{2}{ }^{\mathrm{a}} & \mathrm{F}_{4: 2} & \mathrm{~F}_{6: 2} & \mathrm{~F}_{7: 2} \\ \text { BR-6 } & 1,37 & -5,83 & -0,12 & 0,54 \\ \text { IAS-5 } & -1,65 & 3,03 & -0,24 & -0,08 \\ \text { Davis } & 0,61 & 2,53 & 0,16 & -1,13 \\ \text { OCEPAR-4 } & -0,33 & 0,27 & 0,21 & 0,80 \\ \text { Crockett } & 4,34 & -0,63 & -0,44 & 0,45 \\ \text { Lamar } & 7,99 & -7,38 & -1,89 & -1,63 \\ \text { IAC-100 } & 3,41 & 8,82 & 2,08 & 1,00 \\ \text { D72-9601-1 } & 0,25 & -0,83 & 0,26 & 0,24\end{array}$

Parentais

Populaçōes PRIS

$\begin{array}{lcccc} & F_{2}{ }^{a} & F_{4: 2} & F_{6: 2} & F_{7: 2} \\ \text { BR-6 } & -- & -1,60 & 1,56 & 1,00 \\ \text { IAS-5 } & - & 0,96 & 0,06 & 2,32 \\ \text { Davis } & -- & 3,30 & 0,31 & -1,03 \\ \text { OCEPAR-4 } & -- & -2,42 & -2,54 & -2,28 \\ \text { Crockett } & -- & -16,40 & 0,81 & -0,28 \\ \text { Lamar } & -- & 9,00 & 1,99 & 0,72 \\ \text { IAC-100 } & -- & 9,00 & -0,34 & -0,13 \\ \text { D72-9601-1 } & -- & -2,14 & -2,74 & -0,92\end{array}$

\section{Parentais}

Populações PRIM

\begin{tabular}{lccccc} 
& $\mathrm{F}_{2}{ }^{a}$ & $F_{4: 2}$ & $F_{5: 2}$ & $F_{6: 2}$ & $F_{7: 2}$ \\
BR-6 & $-0,50$ & 0,41 & 0,73 & $-0,81$ & 1,60 \\
IAS-5 & $-0,42$ & $-0,24$ & $-0,62$ & $-0,71$ & 0,18 \\
Davis & 1,06 & $-0,01$ & $-0,04$ & 0,81 & $-0,53$ \\
OCEPAR-4 & $-1,14$ & $-0,16$ & $-0,10$ & 0,95 & $-0,77$ \\
Crockett & $-0,07$ & $-0,06$ & 0,66 & $-0,46$ & 0,28 \\
Lamar & $-1,72$ & 0,54 & $-3,07$ & $-4,92$ & 1,90 \\
IAC-100 & 1,94 & 0,51 & $-0,14$ & 4,29 & 0,83 \\
D72-9601-1 & $-0,14$ & $-0,99$ & 1,78 & $-0,14$ & $-2,10$ \\
\hline
\end{tabular}

a Fonte: Pinheiro (1993). Efeitos $g_{i}$ da CGC sendo a parcela com três fileiras de $2,0 x$ $0,6 \mathrm{~m}$, contendo quatro covas espaçadas $0,5 \mathrm{~m}$. 
Tabela 30. Capacidade média de combinação $\left(\mathrm{cmc}_{\mathrm{i}}\right)$ dos parentais, nos três tipos de populações, para a altura da planta na maturidade $(\mathrm{cm})$ com base no desempenho de suas linhagens dos 16 cruzamentos dialélicos parciais, em Anhembi e ESALQ. Soja, Piracicaba-SP.

Parentais Populações PCI

\begin{tabular}{lcccc} 
& $F_{2}{ }^{a}$ & $F_{4: 2}$ & $F_{6: 2}$ & $F_{7: 2}$ \\
BR-6 & 0,26 & $-0,10$ & 0,05 & 4,19 \\
IAS-5 & $-1,25$ & 1,50 & 0,25 & $-1,79$ \\
Davis & 0,12 & $-0,65$ & $-0,15$ & $-3,21$ \\
OCEPAR-4 & 0,87 & $-0,75$ & $-0,15$ & 1,86 \\
Crockett & 1,37 & 0,00 & 1,97 & $-1,34$ \\
Lamar & $-3,00$ & $-7,80$ & $-5,85$ & $-5,46$ \\
IAC-100 & 2,89 & 8,28 & 5,63 & 6,01 \\
D72-9601-1 & $-1,25$ & $-0,48$ & $-1,75$ & 1,05 \\
\hline
\end{tabular}

Parentais

Populações PRIS

BR-6

IAS-5

Davis

OCEPAR-4

Crockett

Lamar

IAC-100

D72-9601-1

\begin{tabular}{|c|}
\hline$F_{2}{ }^{a}$ \\
\hline$-0,39$ \\
\hline$-0,22$ \\
\hline$-0,11$ \\
\hline 0,73 \\
\hline 0,98 \\
\hline$-0,45$ \\
\hline 0,71 \\
\hline
\end{tabular}

$F_{4: 2}$

$F_{6: 2}$

$F_{7: 2}$

$-1,07$

4,96

2,20

0,21

2,41

1,83

6,08

$-0,49$

$-0,68$

$-5,17$

$-7,56$

$-4,88$

$-10,30$

2,81

$-1,63$

4,55

3,16

$-1,60$

9,01

0,38

1,88

$-1,24$

$-4,35$

$-6,59$

1,08

Parentais

Populações PRIM

\begin{tabular}{lccccc} 
& $\mathrm{F}_{\mathbf{2}}{ }^{\mathrm{a}}$ & $\mathrm{F}_{\mathbf{4} 2}$ & $\mathrm{~F}_{5: 2}$ & $\mathrm{~F}_{6: 2}$ & $\mathrm{~F}_{7: 2}$ \\
BR-6 & 0,06 & $-0,87$ & $-5,59$ & $-5,13$ & 6,45 \\
IAS-5 & 0,12 & 2,31 & 1,43 & $-1,91$ & $-4,65$ \\
Davis & $-1,06$ & $-0,37$ & 0,71 & 1,09 & 0,70 \\
OCEPAR-4 & 0,93 & $-1,07$ & 4,61 & 7,93 & 1,20 \\
Crockett & 1,49 & $-0,19$ & $-1,57$ & 3,87 & 1,58 \\
Lamar & $-2,20$ & $-1,92$ & $-8,89$ & $-16,71$ & $-15,90$ \\
IAC-100 & 2,76 & 2,33 & 12,53 & 9,29 & 5,85 \\
D72-9601-1 & $-2,04$ & $-0,22$ & $-4,29$ & $-0,63$ & 4,60 \\
\hline
\end{tabular}

${ }^{a}$ Fonte: Pinheiro (1993). Efeitos $g_{i}$ da CGC sendo a parcela com três fileiras de 2,0 $\mathrm{x}$ $0,6 \mathrm{~m}$, contendo quatro covas espaçadas $0,5 \mathrm{~m}$. 
Tabela 31. Capacidade média de combinação $\left(\mathrm{cmc}_{\mathrm{i}}\right)$ dos parentais, nos três tipos de populações, para o valor agronômico $(\sqrt{ } x+0,5)$ com base no desempenho de suas linhagens dos 16 cruzamentos dialélicos parciais, em Anhembi e ESALQ. Soja, Piracicaba-SP.

\begin{tabular}{lcccc}
\hline Parentais & \multicolumn{4}{c}{ Populações PCl } \\
\cline { 2 - 5 } & $\mathrm{F}_{\mathbf{2}}{ }^{\mathrm{a}}$ & $\mathrm{F}_{4: 2}$ & $\mathrm{~F}_{6: 2}$ & $\mathrm{~F}_{7: 2}$ \\
\hline BR-6 & $-0,02$ & $-0,04$ & 0,07 & 0,06 \\
IAS-5 & $-0,02$ & 0,01 & $-0,03$ & $-0,02$ \\
Davis & 0,03 & $-0,04$ & $-0,01$ & $-0,05$ \\
OCEPAR-4 & 0,01 & 0,06 & $-0,03$ & 0,03 \\
Crockett & 0,05 & 0,01 & 0,04 & $-0,07$ \\
Lamar & $-0,96$ & $-0,16$ & $-0,08$ & $-0,05$ \\
IAC-100 & 0,97 & 0,16 & 0,07 & 0,10 \\
D72-9601-1 & $-0,05$ & $-0,01$ & $-0,03$ & 0,03 \\
\hline
\end{tabular}

\begin{tabular}{lcccc}
\hline Parentais & \multicolumn{4}{c}{ Populações PRIS } \\
\cline { 2 - 5 } & $\mathrm{F}_{2}{ }^{\mathrm{a}}$ & $\mathrm{F}_{4: 2}$ & $\mathrm{~F}_{6: 2}$ & $\mathrm{~F}_{7: 2}$ \\
\hline BR-6 & -- & $-0,04$ & 0,09 & 0,02 \\
IAS-5 & -- & 0,01 & 0,09 & $-0,01$ \\
Davis & -- & 0,06 & $-0,08$ & $-0,01$ \\
OCEPAR-4 & -- & $-0,04$ & $-0,07$ & $-0,01$ \\
Crockett & -- & $-0,14$ & 0,04 & $-0,01$ \\
Lamar & --- & 0,09 & 0,04 & 0,02 \\
IAC-100 & --- & 0,09 & 0,02 & $-0,01$ \\
D72-9601-1 & -- & $-0,05$ & $-0,11$ & $-0,01$ \\
\hline
\end{tabular}

Parentais

Populações PRIM

\begin{tabular}{lccccc} 
& $\mathrm{F}_{2}{ }^{\mathrm{a}}$ & $\mathrm{F}_{4: 2}$ & $\mathrm{~F}_{5: 2}$ & $\mathrm{~F}_{6: 2}$ & $\mathrm{~F}_{7: 2}$ \\
BR-6 & $-0,05$ & $-0,03$ & $-0,06$ & $-0,12$ & 0,06 \\
IAS-5 & 0,02 & 0,04 & $-0,06$ & 0,08 & $-0,07$ \\
Davis & 0,01 & 0,02 & 0,06 & $-0,07$ & 0,06 \\
OCEPAR-4 & 0,02 & $-0,03$ & 0,08 & 0,13 & $-0,01$ \\
Crockett & $-0,03$ & $-0,01$ & $-0,01$ & 0,03 & 0,03 \\
Lamar & $-0,04$ & $-0,03$ & $-0,15$ & $-0,33$ & $-0,14$ \\
IAC-100 & 0,12 & 0,02 & 0,11 & 0,21 & 0,06 \\
D72-9601-1 & $-0,05$ & 0,02 & 0,01 & 0,01 & $-0,08$ \\
\hline
\end{tabular}

a Fonte: Pinheiro (1993). Efeitos $g_{i}$ da CGC sendo a parcela com três fileiras de $2,0 \mathrm{x}$ $0,6 \mathrm{~m}$, contendo quatro covas espaçadas $0,5 \mathrm{~m}$. 
Tabela 32. Capacidade média de combinação $\left(\mathrm{cmc}_{\mathrm{i}}\right)$ dos parentais, nos três tipos de populações, para a produtividade de grãos ( $\mathrm{kg} / \mathrm{ha}$ ) com base no desempenho de suas linhagens dos 16 cruzamentos dialélicos parciais, em Anhembi e ESALQ. Soja, Piracicaba-SP.

\begin{tabular}{lcccc}
\hline Parentais & \multicolumn{4}{c}{ Populações PCI } \\
\cline { 2 - 5 } & $\mathrm{F}_{2}{ }^{a}$ & $\mathrm{~F}_{4: 2}$ & $\mathrm{~F}_{6: 2}$ & $\mathrm{~F}_{7: 2}$ \\
\hline BR-6 & $-4,20$ & $-101,33$ & 254,14 & 70,90 \\
IAS-5 & $-3,55$ & 114,52 & $-255,14$ & $-54,43$ \\
Davis & 6,87 & $-136,61$ & 95,36 & $-115,93$ \\
OCEPAR-4 & 0,89 & 123,42 & $-94,36$ & 117,19 \\
Crockett & 5,13 & $-28,33$ & $-89,56$ & $-75,46$ \\
Lamar & $-17,93$ & $-188,41$ & $-244,49$ & $-158,33$ \\
IAC-100 & 15,20 & 285,12 & 318,59 & 215,48 \\
D72-9601-1 & $-2,58$ & $-68,38$ & 15,46 & 24,50
\end{tabular}

Parentais

Populações PRIS

$\begin{array}{lcccc} & \mathrm{F}_{2}{ }^{\mathrm{a}} & \mathrm{F}_{4: 2} & \mathrm{~F}_{6: 2} & \mathrm{~F}_{7: 2} \\ \text { BR-6 } & -2,39 & -558,51 & 378,27 & 48,71 \\ \text { IAS-5 } & -2,42 & 161,25 & 420,80 & 2,23 \\ \text { Davis } & 0,37 & 776,36 & 9,07 & -9,09 \\ \text { OCEPAR-4 } & 4,43 & -338,79 & -796,99 & -81,47 \\ \text { Crockett } & -1,80 & -973,16 & 5,75 & -5,27 \\ \text { Lamar } & -4,22 & 550,89 & 671,70 & -62,34 \\ \text { IAC-100 } & 4,97 & 570,66 & -43,70 & 46,61 \\ \text { D72-9601-1 } & 0,33 & -197,85 & -840,65 & 36,73\end{array}$

\begin{tabular}{lccccc}
\hline Parentais & \multicolumn{5}{c}{ Populações PRIM } \\
\cline { 2 - 6 } & $\mathrm{F}_{2}{ }^{a}$ & $\mathrm{~F}_{4: 2}$ & $\mathrm{~F}_{5: 2}$ & $\mathrm{~F}_{6: 2}$ & $\mathrm{~F}_{7: 2}$ \\
\hline BR-6 & $-4,75$ & $-0,86$ & 305,08 & $-361,94$ & 114,86 \\
IAS-5 & 1,39 & 144,54 & 36,20 & 233,31 & $-115,02$ \\
Davis & 1,86 & 198,29 & $-816,40$ & $-222,17$ & 36,44 \\
OCEPAR-4 & 1,50 & $-341,98$ & 633,49 & 467,73 & 40,34 \\
Crockett & $-0,86$ & $-40,48$ & $-68,00$ & $-134,29$ & $-2,67$ \\
Lamar & $-3,59$ & $-285,78$ & $-420,65$ & $-1.268,43$ & $-424,19$ \\
IAC-100 & 5,70 & 301,52 & 881,13 & 909,71 & 200,81 \\
D72-9601-1 & $-1,25$ & 24,74 & $-497,65$ & 175,91 & $-122,79$ \\
\hline
\end{tabular}

Fonte: Pinheiro (1993). Efeitos $g_{i}$ da CGC sendo a parcela com três fileiras de $2,0 \mathrm{x}$ $0,6 \mathrm{~m}$, contendo quatro covas espaçadas $0,5 \mathrm{~m}$. 
Tabela 33. Estimativas dos coeficientes de correlação fenotípica de Pearson entre os caracteres número de dias para a maturidade (NDM), altura da planta na maturidade (APM), valor agronômico (VA) e produtividade de grãos (PG), com base em todos os genótipos a partir da análise envolvendo todos os ambientes

\begin{tabular}{lcccc}
\hline Caracteres & NDM (dias) & APM (cm) & VA (nota) & PG (kg/ha) \\
\hline NDM & $0,54^{\star \star}$ & $0,69^{\star \star}$ & $0,58^{\star \star}$ \\
APM & & $0,80^{\star \star}$ & $0,70^{\star \star}$ \\
VA & & & $0,61^{\star \star}$ \\
\hline
\end{tabular}


Tabela 34. Estimativas dos coeficientes de correlação de Spearman $\left(r_{s}\right)$ entre as gerações de endogamia, com base na média dos cruzamentos, referentes aos caracteres número de dias para a maturidade (NDM), altura da planta na maturidade (APM), valor agronômico (VA) e produtividade de grãos (PG). Soja, Piracicaba-SP.

\section{Corrlações}

\section{Caracteres}

NDM

APM

VA

PG

Populações PCl

$\mathrm{F}_{4} \times \mathrm{F}_{6}$

$0,47^{*}$

$0,58^{*}$

0,30

0,14

$\mathrm{F}_{4} \times \mathrm{F}_{7}$

0,28

$0,53^{*}$

0,39

$0,53^{*}$

$F_{6} \times F_{7}$

$0,74^{\star \star}$

$0,80^{\star \star}$

$0,52^{*}$

$0,45^{*}$

\section{Populações PRIS}

$\mathrm{F}_{4} \times \mathrm{F}_{6}$

0,34

0,46

0,07

0,31

$\mathrm{F}_{4} \times \mathrm{F}_{7}$

0,28

0,44

$-0,29$

0,24

$\mathrm{F}_{6} \times \mathrm{F}_{7}$

0,50

0,47

0,44

$-0,02$

\section{Populações PRIM}

$\mathrm{F}_{4} \times \mathrm{F}_{5}$

$\mathrm{F}_{4} \times \mathrm{F}_{6}$

$\mathrm{F}_{4} \times \mathrm{F}_{7}$

$\mathrm{F}_{5} \times \mathrm{F}_{6}$

$\mathrm{F}_{5} \times \mathrm{F}_{7}$

$F_{6} \times F_{7}$
0,21

0,16

$0,52^{*}$

0,24

$-0,01$

0,12

0,43

0,42

$-0,11$

0,23

0,41
0,12

$-0,08$

$-0,14$

0,01

0,32

0,47

$-0,07$

0,36

0,25

0,39

0,22

0,47

${ }^{*} e^{\star \star}$ : significativo a $5 \%$ e $1 \%$, respectivamente.

1 Os caracteres estão identificados no apêndice 4. 


\section{APÊNDICES}




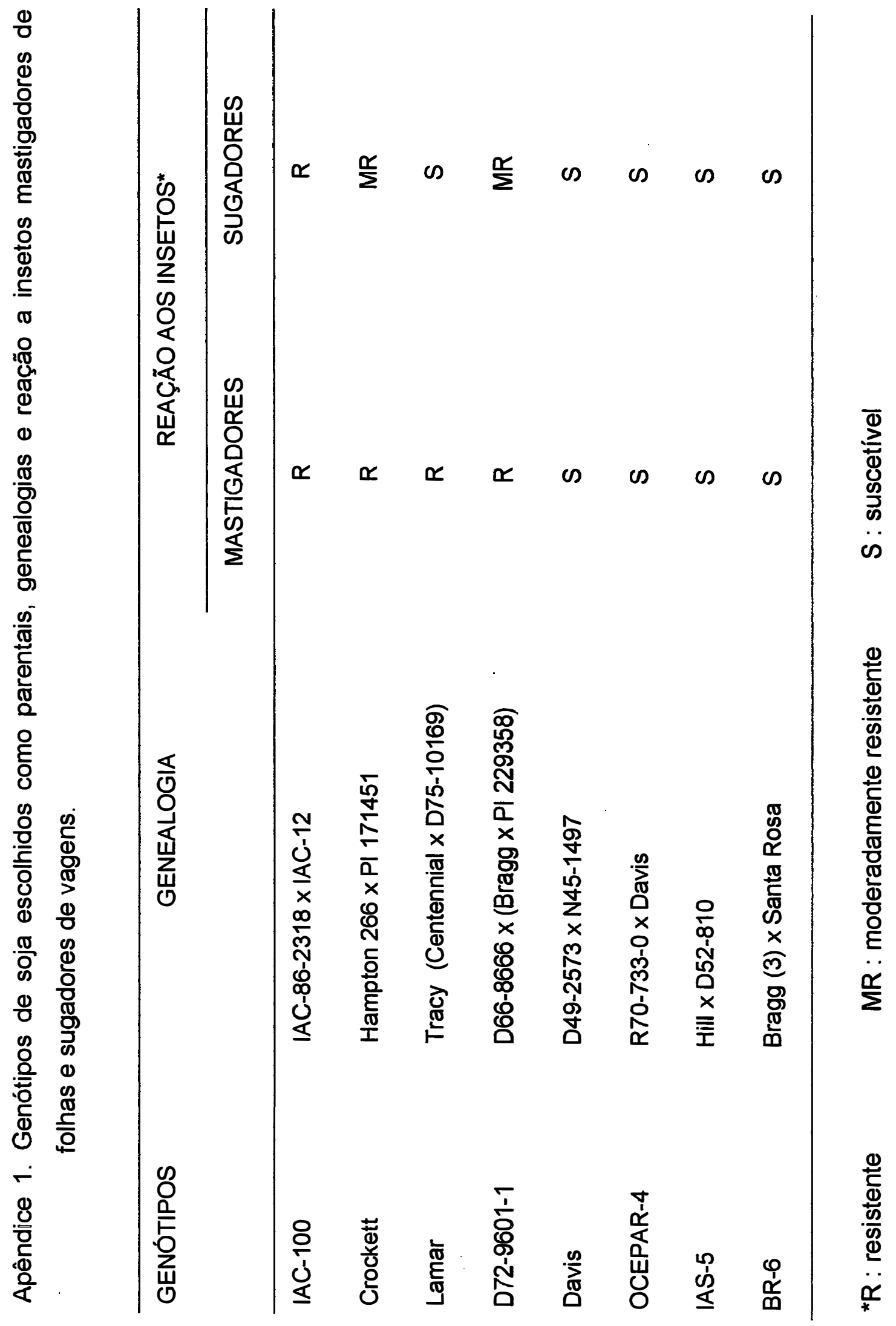




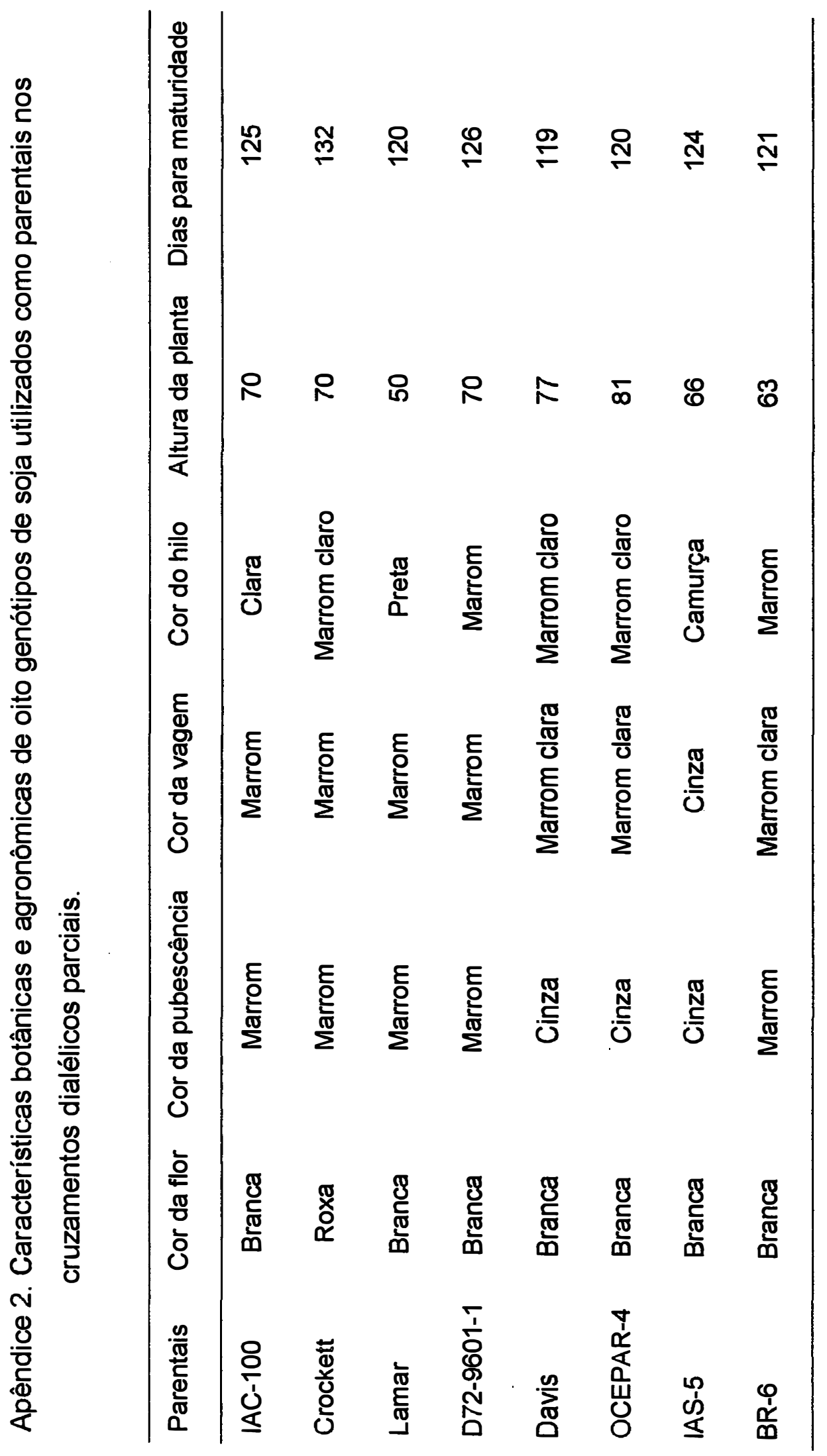




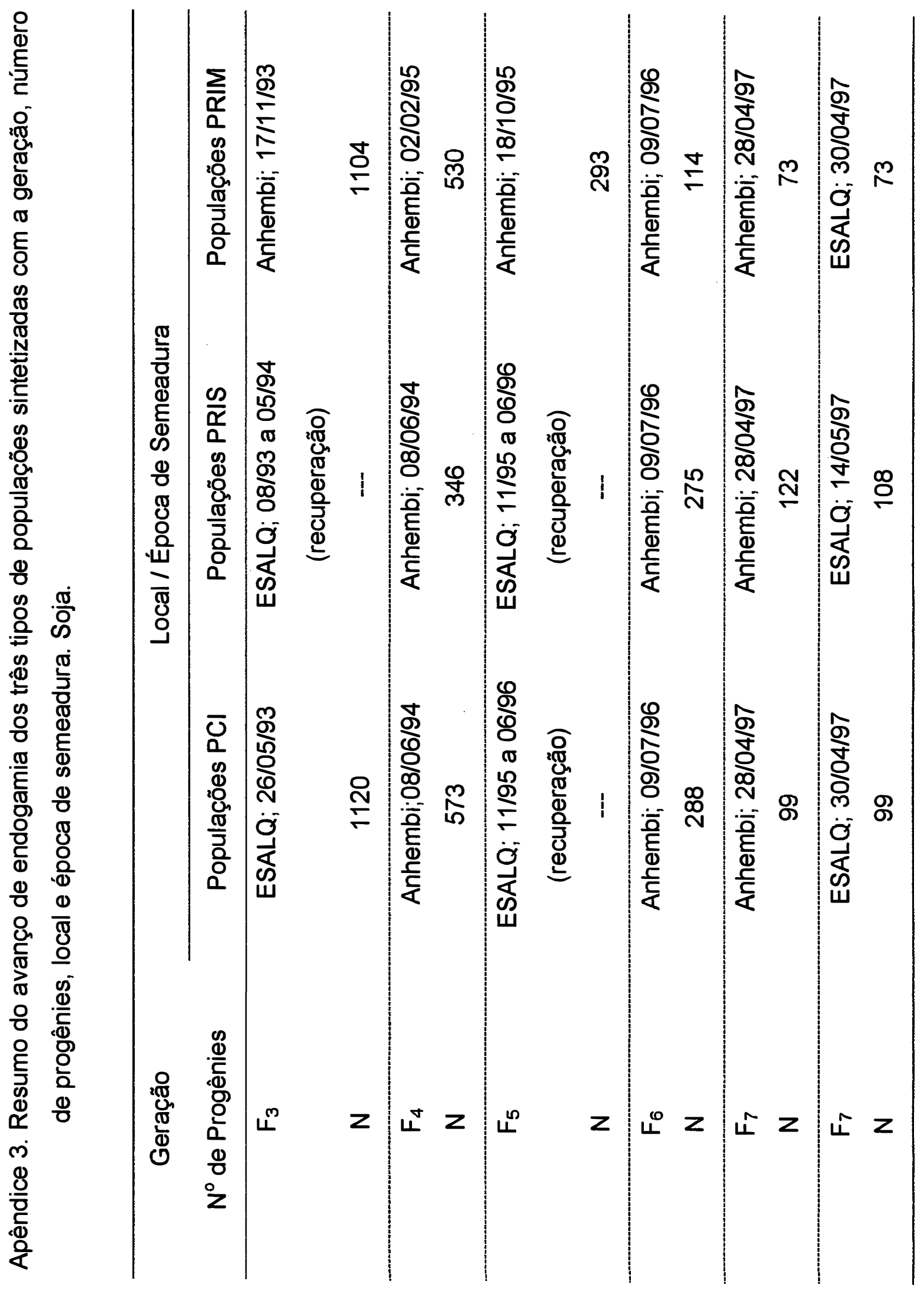


Apêndice 4.

A. Identificação dos 16 cruzamentos dialélicos parciais e dos oito parentais

\begin{tabular}{clcll}
\hline Cruzamentos & \multicolumn{1}{c}{ Descrição } & Cruzamentos & \multicolumn{1}{c}{ Descrição } & Parentais \\
\hline 1 & BR-6 $\times$ Crockett & 9 & Davis $\times$ Crockett & BR-6 \\
2 & BR-6 $\times$ Lamar & 10 & Davis $\times$ Lamar & IAS-5 \\
3 & BR-6 $\times$ IAC-100 & 11 & Davis $\times$ IAC-100 & Davis \\
4 & BR-6 $\times$ D72-9601-1 & 12 & Davis $\times$ D72-9601-1 & OCEPAR-4 \\
5 & IAS-5 $\times$ Crockett & 13 & OCEPAR-4 $\times$ Crockett & Crockett \\
6 & IAS-5 $\times$ Lamar & 14 & OCEPAR-4 $\times$ Lamar & Lamar \\
7 & IAS-5 $\times$ IAC-100 & 15 & OCEPAR-4 $\times$ IAC-100 & IAC-100 \\
8 & IAS-5 $\times$ D72-9601-1 & 16 & OCEPAR-4 $\times$ D72-9601-1 & D72-9601-1 \\
\hline
\end{tabular}

B. Simbologia e identificação dos caracteres:

NDM : número de dias para a maturidade (dias);

APM : altura da planta na maturidade $(\mathrm{cm})$;

VA : valor agronômico (1: péssimo a 5: máximo);

PG : produtividade de grãos $(\mathrm{Kg} / \mathrm{ha})$. 